\title{
I. The Central and Eastern European Judiciary and Transnational Judicial Dialogue on International Law
}

Anna Wyrozumska*

\section{Judicial Dialogue as a Means of Application of International Law}

Some time ago scholars started to study domestic judicial decisions concerning international law hoping to find in them traces of a comparative method. The practice of using cross-references to reasoning and interpretation of law made by other judges became known as 'judicial dialogue.' ${ }^{1}$ Obviously, the notion itself is elusive and gives rise to the conceptual confusion. Judicial dialogue may mean an exchange of ideas in judicial networks; it may refer to the meetings of judges on

* Professor of International and European Union Law, Chair of European Constitutional Law Department, Faculty of Law and Administration, University of Lodz, Poland.

1 On 'transnational judicial dialogue', 'a global community of courts' or 'constitutional comparativism' see e.g.: A.M. Slaughter, 'A Global Community of Courts' (2003) 44, Harvard International Law Review, pp. 191-219; Ch. McCrudden, 'A Common Law of Human Rights? Transnational Judicial Conversations on Constitutional Rights' (2000) 20, Oxford Journal of Legal Studies, pp. 499-532; S. Choudry, 'Globalization in Search of Justification: Toward a Theory of Comparative Constitutional Interpretation' (1999) 74, Indiana Law Journal, pp. 819-892. 
a formal and an informal basis to discuss the law and the process of adjudication; it may denote instances when judges of national or international courts quote each other's decisions when resolving cases before them; or when international and national courts enter into a formalised dialogue (which could be an institutionalized one like in the case of the preliminary reference procedure in the EU which is a formal process through which courts can co-operate with the CJEU). ${ }^{2}$ Despite these approaches, the term 'judicial dialogue' reflects a basic idea according to which the courts communicate with one another, judges know their colleagues' decisions and use them for inspiration, concur or dissent with them, both in an open and silent manner.

Some authors, such as e.g. A.M. Slaughter, offer sophisticated typologies of a 'transjudicial communication'. According to Slaughter, judicial dialogue can be classified on the basis of criteria of its form, function, and reciprocity of communication. ${ }^{3}$ As to the form, a dialogue can be vertical, horizontal, and a mixed vertical-horizontal (depending on the form of subordination between courts). ${ }^{4}$ As far as its functions are concerned, the dialogue could be attitudinal, strategic and normative. It, finally, may enhance the effectiveness of supranational or national courts, enhance the persuasiveness, legitimacy or authority of individual judicial decisions or assure and promote acceptance of reciprocal international obligations. A dialogue may vary also as to the degree of reciprocity.

It may be also argued that it is possible for a court to 'communicate' with other courts without necessarily being explicit about doing so and without drawing attention to the dialogue itself. ${ }^{5}$ That is the case not only in situations of a conflict

2 Torres-Pérez enumerates six prerequisites for dialogue. In addition to the 'common enterprise', dialogue also requires competing viewpoints, common ground for understanding, an absence of competence authority for either party, equal opportunity to participate, and a conversation over time. See: A. Torres-Pérez, Conflicts of Rights in the European Union: A Theory of Transnational Adjudication (Oxford University Press 2009), pp. 97-140.

3 A.M. Slaughter, 'A Typology of Transjudicial Communication' (1994) 29, University of Richmond Law Review, pp. 99-138.

4 E.g. N. Krisch, 'The Open Architecture of European Human Rights' (2008) 71, Modern Law Review, pp. 183-216. The author analysed German, Austrian, Spanish and French courts' approach to the jurisprudence of the ECtHR. He concluded that national courts seek to set limits on the interpretive authority of the ECtHR. He therefore portrays the relationship as one that is more 'horizontal' than 'vertical'. However, the different judiciaries adopt an approach of mutual accommodation to ensure that the practice of human rights law in Europe is more or less harmonious.

5 Similarly, Murphy introduces the distinction between 'implicit' and 'explicit' judicial dialogue. In implicit judicial dialogue, the courts engage in transnational judicial communication without being open or explicit about it. In explicit judicial dialogue, the courts openly acknowledge that communication and the role it plays in resolving conflicting claims to authority. See: C.C. Murphy, 'Human Rights Law and the Challenges of Explicit Judicial Dialogue' Jean Monnet Working Paper 10/12. Similarly, Martinico refers in the EU context to the 'hidden dialogue'. See: G. Martinico, 'A Matter of Coherence in the Multilevel Legal 
between interpretations of norms. It is thus possible to distinguish indirect or 'silent' dialogue and a direct one.

In the research conducted within the framework of the project 'International Law through National Prism' we wanted to examine whether and in what way the Eastern and Central European courts engage in a dialogue on international law. In this publication we are going to look at various instances of references to foreign and international courts decisions of the Central and Eastern European judiciary to see what form they take or function they fulfil and whether there is a degree of reciprocity.

In this contribution we use the concept of judicial dialogue as a tool to examine how courts of new European democracies apply international law. When we started the research few years ago, it seemed that the Central and Eastern European judges who, in most cases, have started to apply international law are, in fact, not so open or prepared to adjudicate on international law and especially to discuss foreign and international courts' decisions. It was thus necessary to look at the judgments containing any kind of reference to foreign or international courts' decisions, independently of the level of involvement in the discussion.

In our research we focused on the examples of Poland, the Czech Republic, Hungary, Lithuania, Russia and Ukraine; all of them are former communist countries. ${ }^{6}$ All of these States are now the members of the Council of Europe, share its values and have become the parties to the European Convention of Human Rights (ECHR) and so are subject to the compulsory jurisdiction of the European Court of Human Rights (ECtHR), and, last but not least, have become parties to the 1969 Vienna Convention on the Law of Treaties (VCLT).

After the collapse of the Eastern Bloc, the legal orders of all the States under examination have experienced the immense transition to a liberal rule of law and market economy. One of the important elements of this transition was a progressive openness to international law. In some countries these processes have started earlier in the eighties of the $20^{\text {th }}$ century, in other in the nineties, and they are much deeper in the countries which later acceded to the EU (Poland, the Czech Republic, Hungary and Lithuania) than in Russia or Ukraine.

The transition necessitated the elaboration of entirely new constitutions. The subsequent integration of States within the EU and within other international organizations has sometimes required further amendments to

System: Are the "Lions" Still "Under the Throne"?' Jean Monnet Working Paper 16/08, New York University, New York.

6 The study is based on country reports prepared in the initial phase of this research project by P. Mikeš (the Czech Republic), N. Chronowski, E. Csatlós, T. Hoffmann (Hungary), V. Vaičaitis (Lithuania), M. Górski, I. Skomerska-Muchowska (Poland), E. Ivanov (the Russian Federation, with collaboration of A. Belyachenkova), and R. Khorolskyy (Ukraine; report distributed among the authors and included in the project files, not published). The country reports are published as e-book accompanying this volume and available at the University of Lodz Repository (RUŁ) website http://repozytorium.uni.lodz.pl:8080/xmlui/. 
the constitutions. Nowadays the constitutions of all the States under examination provide, however in different forms and to a varied extent, for the binding force of international law within the domestic sphere and sometimes explicitly recognize the primacy of international law over domestic law. Yet, that does not mean that international law is applied in an identical way in all these countries. Constitutional authorisation for the binding force of international law is only one of the prerequisites for domestic enforcement of international law, as well as for the use of comparative method or further for judicial communication. This contribution starts with the assumption that judicial dialogue depends primarily on a legal system, a legal basis for the application of international law in a domestic legal order and on a legal culture of a country. This includes the education of the judges, their judicial habits, independence from political authorities etc.

The structure of the contribution follows a simple scheme. We present according to the State by State order the most important features of a legal context in which international law is applied (generally, we do not discuss the EU law) ${ }^{7}$ and on this ground we discuss some patterns of judicial dialogue characteristic for each country and the most interesting identified examples of judicial dialogue.

\section{Poland}

\subsection{The Legal Setting for Judicial Dialogue}

The Polish modern history of international law application in the domestic legal order begins with the regaining of independence after the World War I. The judges started to apply treaties, which, under the Constitution of 1921, were ratified by the President upon the consent of the Parliament granted in a form of a statute. The Supreme Court based its reasoning on the concept of transformation when in 1928 it indicated that "a treaty, when ratified and duly published [...] becomes a statutory instrument and gains a binding force in the domestic legal relations."

7 On the transformation of the Central European judiciary under the EU law see: M. Bobek (ed.), Central European Judges Under the European Influence. The Transformative Power of the EU Revisited, (Hart Publishing, 2015); see also idem, Comparative Reasoning in European Supreme Courts (Oxford University Press 2013); G. Martinico, O. Pollicino, The Interaction between Europe's Legal Systems Judicial Dialogue and the Creation of Supranational Laws (Edward Elgar 2012).

8 Judgment of the Supreme Court of 14 December 1928; similarly, judgment of the Supreme Court of 23 October 1929. 
On the date of publication any ratified treaty started to function in a domestic legal system as a statue. This meant that a subsequent treaty prevailed only over legislative acts earlier in date (lex posterior derogat legi priori). This dualistic approach was confirmed in several judgments of ordinary courts and continued until 1952. ${ }^{9}$ On several occasions, also after 1952, in disputes on diplomatic immunities and State immunity, the courts grounded their decisions on customary international law. ${ }^{10}$

The Constitution of 1952 was silent on international law, reflecting the model developed in the Soviet Union and imposed on all countries of Central and Eastern Europe where international law was not binding within the domestic legal order.

Since the Constitution lacked the provision requiring the consent of the Parliament for ratification, it was difficult to argue that a ratified treaty was transformed into domestic law. There were thus divergent views within the academia on the legality of the direct application of treaties in Polish law with many scholars rejecting such a possibility. On the other hand, some scholars advanced the idea that ratified international treaties entered the domestic legal system through the process of ratification and official publication and should be applied ex proprio vigore. ${ }^{11}$ The concept was implemented by the Supreme Court only in two cases but without success for the applicants since the treaties they had invoked, however binding upon Poland, were neither ratified, nor officially published. ${ }^{12}$ The dominant position of the judiciary was that the direct application of a treaty requires special authorization in a statute applicable to the subject matter of a treaty (e.g. Art. 1 of the Law on private international law of 1965 referred to international treaties as applicable law). Since there were not so many statutes with such endorsements, international law was in this period almost not applied

9 L. Garlicki, M. Masternak-Kubiak, K. Wójtowicz, 'Poland', [in:] D. Sloss (ed.), The Role of Domestic Courts in Treaty Enforcement, A Comparative Study (Cambridge University Press 2013), pp. 370-409. Cf. A. Wyrozumska, 'Poland', [in:] D.L. Shelton (ed.), International Law and Domestic Legal Systems: Incorporation, Transformation, and Persuasion (Oxford University Press 2011), pp. 468-499; eadem, 'Umowy międzynarodowe. Teoria i praktyka' [International Treaties. Theory and Practice] Prawo i Praktyka Gospodarcza (2006), p. 538; R. Kwiecień, Miejsce umów międzynarodowych w porządku prawnym państwa polskiego, [The Position of International Treaties in the Legal Order of the Polish State] (Wydawnictwo Sejmowe 2000), p. 101. For an overview of monistic, dualistic or other models see J. Crawford, Brownlie's Principles of Public International Law (8 $8^{\text {th }}$ ed., Oxford University Press 2012), pp. 48-59.

10 Cf. judgments of 22 October 1925 on diplomatic immunities, Orzecznictwo Sądów Polskich 1926-V, no. 342; and of 2 March 1926 (against Czechoslovakia) Orzecznictwo Sądów Polskich 1926-V, no. 418, cases CR 1272/57 (Supreme Court, 15 May 1959), ICR 58/70 (Supreme Court, 18 May 1970), III CRN 139/79 (Supreme Court, 10 October 1979).

11 S. Rozmaryn, 'Skuteczność umów międzynarodowych PRL w stosunkach wewnętrznych', [The Effectiveness of International Treaties in Poland's Internal Relations], Państwo i Prawo (1962), 12, p. 954.

12 Bug river claims case, 2 CZ 70/61 (Supreme Court, 12 June 1961), Panonia case, III CZP 71/73 (Supreme Court, 5 October 1974). 
by the courts. In 1987 in highly politicized judgment, the Supreme Court held that under the 1952 Constitution there are no grounds to recognise the transformation of a treaty into the domestic legal order. The treaty, which is binding upon Poland has to be implemented by the law, but is not binding as such on the courts. ${ }^{13}$ The position of the Supreme Court reflected an extreme version of the dualistic approach.

In 1989 the process of democratic changes in the Polish legal system has begun. One of its important features was the acceptance of direct application of international law, especially human rights treaties, in the domestic legal order. This facet is characteristic for the democratization processes in all the other States of our concern.

The present Polish Constitution was adopted in 1997. It contains several provisions concerning the relation between international and domestic law. ${ }^{14}$ First of all, the Constitution refers to international treaties. It distinguishes between two general categories of treaties: the treaties ratified by the President and the other treaties concluded by the Government. ${ }^{15}$ The Constitution clearly declares that all the treaties, which are ratified by the President are a part of the law of the land and are generally binding. ${ }^{16}$ According to Art. 91(1) of the Constitution, they shall be applied directly, unless its application depends on the enactment of a statute. The position of a ratified treaty in the Polish legal order depends upon the procedure of ratification. In brief, the Constitution differentiates between treaties ratified upon prior consent of both Chambers of the Parliament given in a form of statute (Art. 90, Art. 89(1) of the Constitution) and treaties, which are ratified without the consent of the Parliament (Art. 89(2) of the Constitution). The Constitution is clear as to the position of the treaties ratified upon prior consent of the Parliament. In case of a conflict with domestic law, the treaty prevails over statutes but not over the Constitution which, pursuant to its Art. 8, is the supreme law of Poland (Art. 91(2) of the Constitution). Further, Art. 188 of the Constitution stipulates for the competence of the Constitutional Court with reference to international law. Pursuant to this provision, the Constitutional Court adjudicates on the conformity of statutes and international treaties to the Constitution, the conformity of a statute to ratified treaties, which required a prior consent granted by

13 Case I PRZ 8/87 (Supreme Court, 25 August 1987). The Supreme Court refused to apply the provisions of ILO Convention No. 87, which was ratified by Poland to the legalisation request of the "Solidarity" trade union and refused to assess whether the domestic legislation on exclusion of trade unions pluralism was consistent with the international obligations of Poland.

14 There are also the references to international law (treaties or customary international law) in various statutes or acts of Government. Taking into account general rule enshrined in the Constitution, they are superfluous.

15 Under Art. 146(4)(10) of the Constitution the Council of Ministers may conclude agreements of an executive nature.

16 Art. 87 of the Constitution. 
a statute, and the conformity of the legal acts of the Government to the Constitution, ratified treaties and statutes.

If taken literally, treaties ratified without a prior consent of the Parliament do not prevail over statutes. As the Constitution contains in its first "Chapter on general principles on which the State is based" 17 Art. 9, which states that "The Republic of Poland shall respect international law binding upon it", the courts begun to understand the hierarchy differently, i.e. all ratified treaties prevail over statutes. ${ }^{18}$ Over the years Art. 9 has been filled with substance by the courts. The judges used to invoke it as a legal basis for domestic effects of all binding treaties other than the ratified ones, for the provisional application of treaties under Art. 25 VCLT, ${ }^{19}$ treaties which are ratified but do not satisfy other conditions of Art. 91 of the Constitution, ${ }^{20}$ customary law, ${ }^{21}$ and the decisions of international organizations or international organs established under the treaties. ${ }^{22}$ The Polish Constitutional Court confirmed in the 2005 judgment on the constitutionality of the EU Accession Treaty, that "Art. 9 expresses an assumption of the Constitution that on the territory of Poland, a binding effect should be given not only to the acts (norms) enacted by national legislature, but also to the acts (norms) created outside the framework of national law-making authorities. The Constitution accepts that the Polish legal system consists of multiple components/elements." ${ }^{23}$ Consequently, Polish authorities, including the judges, should give full effect to international law, i.a. they should develop an interpretation of national law as 'friendly' to international law as possible. ${ }^{24}$

17 The Constitution provides for more stringent conditions for amendment of this Chapter as provided for by its Art. 235(5-6).

18 Cf. e.g. case GSK 56/04 (Supreme Administrative Court, 21 April 2004). Some judges opposed to this effect e.g. the Warsaw Administrative Court held that the freedom of economic activity may not be restricted by a treaty which was ratified in a simplified procedure, i.e. without the consent of the Parliament. Such a treaty may not be invoked for imposing penalties on individuals (case II SA 4156/03, 16 November 2004).

19 Cf. case I SA/ Łd 1707/02 (Supreme Administrative Court, 26 March 2003), in which the Court found that because Poland and Estonia, the parties to the free trade agreement, agreed for its provisional application, to refuse to apply lower custom tariffs provided therein, would infringe upon Art. 9 of the Constitution.

20 For example treaties or the amendments to the treaties which were not officially published in the Dziennik Ustaw (Journal of Laws). See to this effect e.g. case III SA/Lu 16/13 (Lublin Administrative Court, 30 April 2013).

21 See e.g. Natoniewski, III CSK 293/07 (Supreme Court, 13 March 2010).

22 E.g. cases I SA/Sz 414/07 (Szczecin Administrative Court, 3 October 2007) concerning the effects of the decision of the Mixed Commission EC/EFTA; I SA/Go 559/06 (Gorzow Administrative Court, 22 March 2007); I GSK 813/07 (Supreme Administrative Court, 22 July 2008). Case K 18/04 (Constitutional Court, 11 May 2005) on the EU Accession Treaty of 2003, para. 2.2. Art. 9 of the Constitution became the basis of the consonant (friendly) interpretation (indirect application of treaties), see to this effect e.g. case II PK 100/05 (Supreme Court, 29 November 2005) in which the Court recognised its obligation stemming from Art. 9 of the Constitution to interpret domestic law as far as possible in concordance with the terms of the non-ratified treaty which is binding on Poland; case V SA 859/99 (Supreme Administrative 
The clear and complete provisions contained in the treaties, which are ratified and officially published may be directly applicable (Art. 91(1) of the Constitution). The concept of 'directly applicable' or 'self-executing' treaty provisions had been well established by the Polish courts long before the 1997 Constitution was adopted. ${ }^{25}$ The judges obviously drew from experiences of the US Supreme Court (the 1829 landmark decision in Foster \& Elam $v$ Neilson) ${ }^{26}$ but they had not mentioned the relevant cases. Similarly, when Poland became the member of the EU, they started to follow the formula devised by the Court of Justice of the European Union (CJEU) for conditions of direct applicability of EU law established in 26/62 Van Gend en Loos and subsequent cases without references to these sources (silent dialogue). For example, in the judgment of 2006 the Supreme Administrative Court found Art. 33 of the Agreement on Trade-Related Aspects of Intellectual Property Rights (TRIPS) to be a clear, unconditional and a complete provision, which may be invoked by an individual against the State. ${ }^{27}$

The treaties concluded in any other procedure than ratification cannot be directly enforced by courts. They bind only the State organs and to impose obligations on individuals they have to be implemented by universally binding acts of the Parliament or the Government. However, the courts found several other effects these treaties may produce owing to the fact that they bind upon the State. ${ }^{28}$ For example, if a treaty is inaccurately or not fully implemented, it may give rise

Court, 1 February 2000) where the Court inaccurately assumed that since Poland acceded to the Refugee Convention of 1951, the Convention was not a ratified treaty under the Constitution (the document of the President which was officially published had not referred to ratification but to accession). Consequently, it was not possible to apply it directly. However, the Court assured effectiveness to the provisions of the Convention invoking Art. 9 of the Constitution and interpreting domestic law consistently with the Convention.

Cf. cases K 8/91 (Constitutional Court, 7 January 1990); I PRN 54/93 (Supreme Court, 15 June 1993); II KRN 274/91 (Supreme Court, 17 October 1991).

26 Case 27 U.S. (2 Pet.) 253 (1829), p. 254: "In the United States, a different principle is established. Our Constitution declares a treaty to be the law of the land. It is consequently to be regarded in courts of justice as equivalent to an act of the legislature whenever it operates of itself, without the aid of any legislative provision. But when the terms of the stipulation import a contract, when either of the parties engage to perform a particular act, the treaty addresses itself to the Political, not the Judicial, Department, and the Legislature must execute the contract before it can become a rule for the Court."

27 Case II GSK 54/05 (Supreme Administrative Court, 8 February 2006); cf. A. Wyrozumska, 'Poland' (n. 10), p. 483. The provision of TRIPS reads: "The term of protection available shall not end before the expiration of a period of twenty years counted from the filing date."

28 E.g. if a treaty had been executed, its legal effect could be irreversible, see to this effect case SK 31/99 (Constitutional Court, 24 October 2000) concerning the 1960 compensation agreement concluded by Poland with the USA. Poland paid the US government in order to compensate for financial claims of the US citizens linked to expropriation from land located on the Polish territory. According to the agreement, to obtain the compensation from the US government it was necessary to renounce property rights. The Constitutional Court found that the effect produced by this act is now irreversible. Cf. case II CSK 456/13 (Supreme Court, 24 July 2014). 
to legitimate expectations of individuals. In the 2002 judgment concerning the socalled Bug River claims the Constitutional Court held that although the treaties concluded by Poland after the World War II with the Soviet Republics (Lithuania, Belarus and Ukraine) providing i.a. for compensation for a loss of property left by repatriates on the former Polish territories beyond the Bug river, though not ratified treaties, gave rise to legitimate expectations of the Polish citizens that internal law would regulate relevant financial settlements. ${ }^{29}$ The Court observed that the Parliament has been for many years trying to establish specific compensation mechanisms but has not completely succeeded. Individuals therefore have still valid compensation claims against the State. The judgment goes in hand with the position taken later by the ECtHR in the landmark Broniowski decision in which the ECtHR found a systemic problem connected with the malfunctioning of the Polish legislation and practice and applied for the first time the pilot-judgment procedure. ${ }^{30}$

Some courts gave effect to non-ratified treaties on the basis of a general clause in a statute pertinent to the subject matter of a treaty. The clause enumerated as applicable law international treaties, not specifying that they have to be ratified or concluded under a different procedure. Those courts argued that such clause is redundant if understood to encompass only ratified treaties since the same result stems from the Constitution. For the clause to be effective, it has to be treated as authorization to apply treaties which otherwise would not be used. It then incorporates a treaty into a statute. In consequence, the legal force of a non-ratified treaty is equal to a statute. ${ }^{31}$

These few examples show that there is a good legal environment for application of international law in Poland and that many judges are open to international law.

\subsection{Deference to International and Foreign Courts Decisions}

\subsubsection{References Prompted by Applicants or Made Proprio Motu}

In majority of cases the judges, especially of ordinary courts, apply international law without any reference to foreign or international courts' decisions. However, sometimes they find it necessary to discuss such judgments, mostly to support or to distinguish their own argumentation. This practice, except for the ECHR and EU law, is not common probably because it requires a much better expertise on international law of both the judges and the parties to the dispute, than an application of a treaty provision. ${ }^{32}$ This volume contains comprehensive analysis

29 Case K 33/02 (Constitutional Court, 19 December 2002).

30 Broniowski v Poland, App. no. 31443/96 (ECtHR, 22 June 2004).

31 See to this effect e.g. case OSA 2/98 (Supreme Administrative Court, 17 May 1999).

32 On application of the ECHR and EU law see e.g. K. Kowalik-Bańczyk, 'Report on Poland', [in:] G. Martinico, O. Pollicino (eds), The National Judicial Treatment of the ECHR and EU 
of the Polish practice, it seems thus enough to signal some problems and present few representative decisions here (see contributions by Skomerska-Muchowska, Górski, Matusiak, Czaplińska in this study).

In contradictory court proceedings a lot depends on arguments of parties. If experienced lawyers represent them, the arguments based on international law are better substantiated. This happens frequently in the area of human rights. However, such approach cannot guarantee success as the example of the 2014 Warsaw Administrative Court judgment confirms. It concerned deportation of a foreigner on the basis of a classified report prepared by the Internal Security Agency. ${ }^{33}$ The applicant claimed that he was refused access to the case files since they were confidential; therefore, his right to court was infringed. He invoked and discussed several relevant judgments of the ECtHR ${ }^{34}$ and the CJEU decision of 3 September 2008 in C-402/05 P and C-415/05 P Kadi v Council and Commission to support the claim to the right to know the reasons of the decision issued against him. The Warsaw Administrative Court concluded from the judgments presented by the applicant that the right to court, which includes the principle of contradictoriness and as an essential element the possibility to get acquainted with the information in possession of the authority or the court is not a value overriding other values protected by the national legal order. Disclosing information gathered by a specialised agency responsible for State security enables identification of the source of information, so it can pose a threat to other persons or even exclude the possibility of obtaining any further relevant information. In such situation the limitations on procedural rights of a person are justifiable on account of public interest.

The Court made itself familiar with the classified case files and decided that the deportation decision was justified. This cannot be questioned, as the Court noted, neither by the applicant nor his legal representative because they cannot get acquainted with the said case files. At the same time the Court cannot include full argumentation in the reasons of the judgment because of the need to protect classified information. The Court finally observed that the present case does not concern fundamental issues such as protection of life or health, long-term deprivation of liberty or property rights. It concerns the possibility to limit the freedom of movement for a defined period (5 years) and for a defined geographic area (Schengen area, were neither the foreigner nor his family are citizens of any of the countries covered by it). Of course such a ban can impact upon an applicant's private or professional life, but it has to be weighed against the public interest - protection of State security.

Laws, A Comparative Constitutional Perspective, (Groningen: Europa Law Publishing, 2010), pp. 329-349.

34 C.G. v Bulgaria, App. no. 1365/07 (ECtHR, 24 July 2008); Lupsa v Romania, App. no. 10337/04 (ECtHR, 8 June 2006); Liu v Russian Federation, App. no. 42086/05 (ECtHR, 6 December 2007); Chahal v the UK, App. no. 22414/93 (ECtHR, 15 November 1996). 
It is a pity indeed that the Court did not refer to other judgments in Kadi saga issued after 2008, i.e. to the decisions of the General Court of 2010 and the EU Court of Justice of 2013. ${ }^{35}$ It must be acknowledged that even if they were not mentioned, the Warsaw Administrative Court did try to take part in a judicial dialogue pointing to specific circumstances of the case at issue. ${ }^{36}$ In a similar case, the same Court, albeit in different composition, did not recognise such a need. It only made a general remark (without giving any details of specific decisions) that in any of the judgments invoked by the applicant the CJEU neither condemned the use of classified information nor afforded to the applicants an unrestricted right to have access to the files.

The second exemplary decision was authored by the Supreme Administrative Court and demonstrates that judges refer to the judgments from other jurisdictions also if not prompted by the applicants. The case at stake is interesting, since it addresses the problems concerning the legal effect of various international law acts or instruments, which are not formally treaties. In the $2010 \mathrm{Su}$ preme Administrative Court judgment, the Court had to answer the question whether the Administrative Regulations of the International Telecommunication Union may be directly applied in Poland if they had not been officially published. ${ }^{37}$ Poland, at the same time did ratify and publish the 1992 Constitution and the Convention of the International Telecommunication Union. Pursuant to Art. 54 of the Constitution, the Administrative Regulations (adopted by the conference of all the members, the supreme organ of the Union) are binding. Moreover, the consent to be bound by the Constitution and the Convention is tantamount to the consent to be bound by the Administrative Regulations adopted by the competent world conferences prior to the date of their signature. The specific issue in the case at hand was whether it is possible to impose taxes on individuals in accordance to the principles (more lenient than in the Polish tax law) elaborated by the ITU Administrative Regulation, which was not published. The Supreme Administrative Court did not fully concur with the reasoning of the first instance administrative court that the acts of international organisation, which under the treaty establishing that organisation are binding on its members, if not published in the Journal of Laws, may bind Poland only in external relations (as they do not satisfy the criteria established in Art. 91 of the Constitution). Such regulations may produce internal effects merely to the extent they were implemented in the domestic law. Contrary to this finding, the Supreme Administrative Court distinguished between two situations: where such provisions grant rights to individuals and when they provide for obligations. While it is not possible to impose obligations on individuals on the basis

35 Respectively, T-85/09 Kadi v Commission (GC, 30 September 2010); Joined Cases C-584/10 P, C-593/10 P and C-595/10 P Commission, Council and the United Kingdom v Kadi (CJEU, 18 July 2013).

36 Case IV SA/Wa 1260/14 (Warsaw Administrative Court, 23 October 2014).

37 Case I FSK 92/09 (Supreme Administrative Court, 11 March 2010). 
of such an act, individuals may rely on it against the State when their rights are concerned. To come to this conclusion the Court referred to the similarities of the dispute before the CJEU in C-161/06 Skoma-Lux ${ }^{38}$ in which the Court found that the obligations contained in the Community legislation, which has not been officially published, cannot be enforced on individuals, even though those persons could have learned of that legislation by other means. The Supreme Administrative Court concurred with that reasoning and underlined that it may be applied also to the situation, which is not covered by EU law. Since the applicant (the company) relied on rights, the Court held that it may invoke the provisions of the relevant Administrative Regulation even if it had not been published. ${ }^{39}$

\subsubsection{Identification of Customary International Law - Skrzypek, Natoniewski and Nigerian Embassy}

There are several judgments of the Polish ordinary courts under the Constitution of 1997 grounded in customary international law. In the majority of cases they determine customary law in a general (simplified) way referring to the conventions codifying custom or the opinions of scholars. The decision of the Warsaw Provincial Court in Skrzypek v Germany is special since the Court (in that case the lower court) referred to other jurisdiction, to the judgment of the CJEU: C-292/05 Lechouritou. ${ }^{40}$ It thus supported the finding that State immunity covers as an act de jure imperii - a legal action brought by natural person in one State against another State (namely Germany) for compensation in respect of the loss or damage suffered by the successors of the victims of acts perpetrated by armed forces in the course of warfare (World War II) on the territory of the first State. The Court observed that also the CJEU found the situation at issue to be a 'civil

38 C-161/06 Skoma-Lux sro v Celní ředitelství Olomouc (CJEU, 11 December 2007).

39 It is not the first judgment of that kind, distinguishing between different effects in respect of rights or obligations, but probably the first one to refer to rights and to support the argument by the judgment from other jurisdiction. See e.g. Karin Galstyan, V SA 726/99 (Supreme Administrative Court, 7 December 1999) concerning unpublished diplomatic note of Armenia declaring discontinuation of the Soviet Union treaties after succession and the consequences of the lack of publication of official statement on termination towards Armenia of the treaty between Poland and the Soviet Union on visa-free movement of persons. The Court based its reasoning on the Constitution finding that Mrs Galstyan could not have be obliged to possess visa if she had not been duly informed of this duty by the State. In I GSK 813/07 (Supreme Administrative Court, 22 July 2008) the Court referred to Skoma Lux as well but the case concerned obligations of individuals and only partly EU law, cf. case II GSK 640/13 (Supreme Administrative Court, 24 June 2014). In this context it is worth to note the case I SA/Bd 275/05 (Bydgoszcz Administrative Court, 20 July 2005) dealing exactly with a Skoma Lux type of a situation. The Court did not refer to the CJEU for preliminary ruling but on the ground of the principle of certainty of law came to the same conclusion as the CJEU.

40 C-292/05 Irini Lechouritou et al. v Dimosio tis Omospondiakis Dimokratias tis Germanias (CJEU, 15 February 2007). 
matter' (acta de jure gestionis). In the opinion of the Polish Court, even if the judgment of the CJEU refers to a concrete dispute on the application of the Brussels Convention on Jurisdiction and the Enforcement of Judgments in Civil and Commercial Matters of 1968, it also expresses a general idea which is applicable likewise to the case at hand.

Skrzypek concerns the same issues as Natoniewski $v$ Germany ${ }^{41}$ discussed elsewhere in this volume (see Matusiak, para. 2. B). The difference is that Mr. Skrzypek probably did not argue for the exception to State immunity in respect of acta de jure imperii and the Court did not detect the issue by itself. The plaintiff in $\mathrm{Na}$ toniewski maintained in the cassation procedure that Germany is not entitled to immunity applicable to the case before the Polish courts for two reasons. First, immunity as to acta de jure imperii does not extend to torts or delicts occasioning death, personal injury or damage to property committed on the territory of the forum State. Secondly, irrespective of where the relevant acts took place, Germany was not entitled to immunity because those acts involved the most serious violations of rules of international law of peremptory character for which no alternative means of redress was available.

The Supreme Court took up the challenge to discuss timely and highly controversial questions. To come to the same conclusion as in Skrzypek, the Court did not invoke one case, but carefully discussed various opinions expressed by the judges of international and foreign courts. The Supreme Court judgment in Natoniewski was subsequently discussed by other courts, the International Court of Justice (ICJ) in Germany $v$ Italy ${ }^{42}$ and by the ECtHR in Jones and Others $v$ the United Kingdom. ${ }^{43}$ No doubt owing to its English translation in Polish Yearbook of International Law it took part in exchange of ideas and opinions on important issues of international law.

The judgment of the 2014 Warsaw Appellate Court on immunity from execution (Nigerian Embassy case) was not yet translated into English but it is equally worth mentioning. The Court repealed the judgment of the lower court rejecting the possibility of the execution of the judgment against the Embassy of Nigeria in an employment dispute providing for the renewal of employment contract under the threat of financial penalty and ordered the reconsideration of the case. The main reason was that the lower court inaccurately viewed the case in the light of the 1961 Vienna Convention on Diplomatic Relations instead of relying on customary international law on State immunity. The Warsaw Appellate Court tried then to indicate that the claim against embassy of a foreign State is the claim against

41 Case IV CSK 465/09 (Supreme Court, 29 October 2010).

42 Jurisdictional Immunities of the State (Germany v Italy: Greece Intervening) (ICJ, 3 February 2012) paras 68, 74, 85, 96, citing English translation in (2010) XXX Polish Yearbook of International Law 299.

43 Jones and Others $v$ the United Kingdom, App. no. 34356/06 and 40528/06 (ECtHR, 14 January 2014) para. 144, citing English translation in (2010) XXX Polish Yearbook of International Law 299. 
a State and has to be viewed in the light of the rules determined i.a. in the 2010 decision of the ECtHR in Cudak ${ }^{44}$ and in the 2012 CJEU judgment in C-154/11 Mahamdia. ${ }^{45}$ Both Cudak and Mahamdia are premised on the idea that under international customary law State immunity does not cover acts de jure gestionis such as contracts of employment with persons who do not perform functions which fall within the exercise of public powers. As concerns the immunity from enforcement, for general rules, the Appellate Court referred to the judgment of the ICJ in Germany v Italy. But the most interesting are the arguments developed by the Warsaw Court on the ground of three decisions of the courts of Germany, the United Kingdom and France concerning the execution from the embassy's bank account. ${ }^{46}$ The Court observed:

\begin{abstract}
Having regard to the development of international law and the recent case law, as the CJEU judgment mentioned above, in which the need to protect the rights of employees was strongly emphasised, it is crucial to consider the possibility of execution from the embassy bank account, used for payments for employees who are the citizens of a State forum, which have not carried out sovereign activities. If the embassy decides to employ workers and routinely uses its bank account to pay them salaries, it cannot be categorically held that their claims cannot be satisfied from such bank account. It is obviously a sensitive issue, which has to be analysed in the circumstances of each case but - in the opinion of the Appellate Court - such a solution may not be $a$ priori rejected. ${ }^{47}$
\end{abstract}

The suggestion of the Appellate Court addressed to the lower court to look for a possibility for execution from a bank account seems controversial. It is disappointing that the Court based itself on three judgments only and did not take into account the specificity of the judgment of the CJEU (which interpreted the relevant EU regulation). The other problem with the decision of the Appellate Court is that the Court said nothing about the renewal of employment and referred simply to the threat of financial penalty. The Court found it to be 'questionable, "since it directly interferes in the principle of respect of States equality" 48 but instructed the lower court to study this issue carefully.

The case proves that at least some judges, when confronted with issues not regulated by domestic law or new problems, are capable of making an effort to look for an answer or inspiration to other jurisdictions. The extent and the depth of the study of international or foreign judicial decisions pose a real problem as well as the accuracy of conclusions drawn from the relevant case law.

44 Cudak v Lithuania, App. no. 15869/02 (ECtHR, 23 March 2010).

C-154/11 Ahmed Mahamdia v People's Democratic Republic of Algeria (CJEU, 19 July 2012).

Philippinische Botschaft, 2 BvM 1/76 (German Constitutional Court, 13 December 1977) 46, p. 342; Alcom Ltd. v Republic of Colombia (House of Lords, 12 April 1984); Islamic Republic of Iran v Société Eurodif and others, 82-12462 (French Cour de Cassation, 14 March 1984).

Case XXI Pz 95/14 (Warsaw Appellate Court, 26 June 2014).

Ibidem. 


\section{The Czech Republic}

\subsection{The Legal Setting for Judicial Dialogue}

The history of application of international law and the relevant provisions of the 1991 Czech Constitution (as amended in 2002) bear many similarities to the Polish case study. ${ }^{49}$

As in Poland under the communist regime, the 1949 Constitution of Czechoslovakia (similarly to the previous Constitution of 1920) was silent on a relation between international and national law (except for the final two years of the existence of the country).$^{50}$ The scholars diverged in opinions as to the application of a treaty ex proprio vigore and international law was not applied if specific statutes had not contained provisions authorising the application of a treaty or customary law. After the Velvet Revolution in November 1989 the country opened significantly to international law, became a party to the ECHR and recognised the jurisdiction of the ECtHR. The Constitution was amended to incorporate human rights treaties ${ }^{51}$ and the Constitutional Court of the Czech and Slovak Federal Republic established in 1991 started to invoke the International Covenant on Civil and Political Rights and the International Covenant on Economic, Social and Cultural Rights. After the dissolution of Czechoslovakia (in effect of 1 January 1993) the Constitution of the Czech Republic retained the same formula incorporating to domestic law only human rights treaties. ${ }^{52}$ In 2001 the Constitution of 1993 was amended. The 1997 Polish Constitution inspired this so-called Euro-amendment. Article 19(2) of the Czech Constitution corresponds to Art. 9 of the Polish Constitution stating that "[t]he Czech Republic shall observe its obligations resulting from international law." There are also similarities between Art. 10 of the Czech Constitution and Art. 91 of the Polish Constitution. The former states that "[p]romulgated treaties, to the ratification of which the Parliament has given its consent and by which the Czech Republic is bound, form a part of the legal order; if a treaty provides something other than

49 See P. Mikeš, 'Czech Courts and International Law' (2011) 2, Czech Yearbook of International Law 290; A.J. Bělohlávek, 'The Czech Republic', [in:] D.L. Shelton (ed.), International Law and Domestic Legal Systems: Incorporation, Transformation, and Persuasion (Oxford University Press 2011) pp. 195-206.

50 The Constitutional Act No. 23/1991 Coll. of 9 January 1991 adopted by the Federal Assembly of the Czech and Slovak Federal Republic introduced the Charter of Fundamental Rights and Freedoms as a constitutional law, entered into force on 8 February 1991.

51 The Constitutional Act No. 23/1991 Coll., section 2 reads: "International treaties on human rights and fundamental freedoms that the Czech and Slovak Federal Republic ratified and promulgated are generally applicable on its territory and take precedence over the law."

52 The Constitutional Act No. 1/1993 Coll., the Constitution of the Czech Republic - enacted on 16 December 1992, with effect as off 1 January 1993. 
that which a statute provides, the treaty shall apply." 53 The specific provision addressed to the judges of Art. 95(1) declares in a novel manner that "[in] making their decisions, judges are bound by statutes and international treaties which form a part of the legal order; they are authorized to judge whether enactments other than statutes are in conformity with statutes or with such international treaties." The Euro-amendment removed from the Constitution the provision on human rights treaties.

There are also provisions in specific statutes authorising the application of international law, some of them are relicts of the previous system and refer only to human rights treaties, obsolete after the constitutional amendment. Occasionally they may create confusion. ${ }^{54}$

From the perspective of judicial dialogue on international law it is worth to mention that the Constitution gives the Constitutional Court the power to enforce international courts' decisions. In practice, however, it is rarely used. ${ }^{55}$ Under Art. 87(1)(i) of the Constitution, the Constitutional Court has jurisdiction to decide on the measures necessary to implement a decision of an international court which is binding on the Czech Republic, in the event that it cannot be otherwise implemented. ${ }^{56}$ The Constitutional Court Act in paras 118 and 119 specifies that the Constitutional Court may adjudicate upon the petition proposing the annulment of the provisions found by an international court as violating international law or the petition of rehearing if the Constitutional Court "have decided in a matter in which an international court found that, as the result of the encroachment of a public authority, a human right or fundamental freedom was infringed in conflict with an international treaty". The term 'international court' was defined in para. 117 of the Act on the Constitutional Court as "any international body whose decisions are binding for the Czech Republic pursuant to an international treaty which forms a part of the legal order". The present formula of para. 117 however referring not to the court but to any body, still could be interpreted as excluding the views adopted by the quasi-judicial body like the UN Human Rights Committee (HRC). ${ }^{57}$

International treaties are a part of the legal order of the Czech Republic and can be directly applied by the courts. Czech courts distinguish between different categories of treaties and give them different position in the hierarchy of legal acts

53 Art. 10a of the Czech Constitution resembles Art. 90 of the Polish Constitution, Art. 49 - Art. 89 of the Polish Constitution etc.

54 See P. Mikeš, 'Country Report Czech Republic', para. I.2.

55 The examples are the Constitutional Court cases: PI. ÚS 28/11 (24 April 2012); PI. ÚS 13/06 (6 May 2008); Pl. ÚS 1/07 (6 May 2008); Pl. ÚS 1/09 (28 July 2009); Pl. ÚS 19/12 (18 December 2012).

56 The provisions were amended in 2012 with the effect off 1 January 2013, they are inserted in part 8 of the Constitutional Court Act (no. 182/1993 Coll.) para. 117-119b.

57 In the General Comment No. 33 (2008), the HRC noted that even though it is not a judicial body, its Views "exhibit some important characteristics of a judicial decision." 
(different position than the same treaties have in Poland). The highest place is granted to treaties, which transferred certain powers of public authorities to an international organization or institution (ratified under Art. 10a of the Constitution with a prior consent of the Parliament given by qualified majority of $3 / 5$ in both chambers of the Parliament - 3/5 of all MP and 3/5 of present senators). These treaties take precedence even over the Constitution except for the so-called hard core of the Constitution.

The second category is made up of human rights treaties. They are not distinguished by the wording of the Constitution but their special position of acts having constitutional character originates in the doctrine developed by the Constitutional Court. ${ }^{58}$ The Constitutional Court observed also that direct application of international treaties includes the obligation of Czech courts and other public authorities to take into account the interpretation of these treaties by international tribunals as authorities called upon to pronounce authoritatively on the interpretation of international treaties. This, of course, also applies to interpretation of the ECHR by the ECtHR. Moreover, "the relevance of the ECtHR jurisprudence achieved constitutional law quality in the Czech Republic." ${ }^{59}$ Since 2002 the Constitutional Court tried to put itself in a stronger position in relation to ordinary courts by obliging them to submit the case to the Constitutional Court, if they find a conflict between a human rights

58 Case I. ÚS 310/05 (Constitutional Court, 15 November 2006): “A special position among them [international treaties] have international treaties on human rights and fundamental freedoms which form part of the Czech constitutional order with all the resulting consequences [...]."

59 Ibidem: "The immediate applicability of international treaties also includes the obligation of Czech courts and other public authorities to take into account the interpretation of these treaties by international tribunals as authorities called upon to pronounce authoritatively on the interpretation of international treaties. This of course also applies to the interpretation of the ECHR by the ECtHR. The relevance of the ECtHR jurisprudence achieved constitutional law quality in the Czech Republic. ECtHR decisions are for the Czech Republic and for public authorities on its territory binding in an individual case, which also comes from Article 46, paragraph 1 of the ECHR [...]. For the reasons mentioned above, however, have public authorities a general duty to take into account the interpretation of the ECHR carried out by the ECtHR. [...] Public authorities, in the first place then the courts, are therefore obliged to take into account the case law of the ECtHR as well as in the cases where decisions concerned the Czech Republic as well as in the cases that concerned another Member State of the ECHR when these cases were, by its nature, significant also for the interpretation of the ECHR in the Czech context. This duty is of special importance if a party before a Czech court points out to such case law. If such an argument is omitted by a court then the court commits a misconduct, which could lead to the infringement of the fundamental right to judicial protection under Article 36 paragraph 1 of the Czech Charter of Fundamental Rights and Freedoms, Article 6 paragraph 1 of the ECHR, eventually of the respective fundamental right guaranteed by the ECHR. In any case also Article 1 paragraph 2 of the Czech Constitution is affected." 
treaty and domestic law. ${ }^{60}$ The Constitutional Court will then have an exclusive competence to adjudicate upon such conflict and repeal domestic norm if relevant. ${ }^{61}$ This doctrine was, however, opposed to. The Supreme Administrative Court refused to apply it on several occasions and adjudicated on the conflict giving precedence of application to a treaty norm. ${ }^{62}$ The Supreme Administrative Court observed "that the conclusion of the Constitutional Court was stated obiter dictum without any connection with the decided case. The conclusion was not justified in detail and in the following scholarly discussions strong critique was voiced against the judgment. In this situation, the Supreme Administrative Court finds it impossible to give regard to the clear wording of the constitutional guideline." ${ }^{63}$

In its practice the Constitutional Court considered obligations under the human rights treaties as prevailing over any other treaty obligations. These cases concerned extradition resulting in a risk that the person concerned would be exposed to torture, inhuman or degrading treatment.$^{64}$ For example, in the decision of 2013, referring to its jurisprudence, the Constitutional Court observed that if the non-refoulement principle under the 1951 Convention relating to the Status of Refugees collides with the obligation to extradite, the conclusion expressed earlier that "the respect and protection of fundamental rights are defining elements of the substantively understood state governed by the rule of law" shall apply. "[T]herefore, in a case where a contractual obligation protecting a fundamental right and a contractual obligation which tends to endanger that same right exist side by side, the first obligation must prevail." ${ }^{65}$

The third category of international treaties encompasses those, which were ratified upon a prior consent of the Parliament and promulgated in the Czech Official Journal (Art. 10 of the Constitution). Their norms are directly applicable and have a priority over conflicting statutory provisions (laws).

All the other treaties, concluded under other procedures, ratified without a consent of the Parliament or concluded by the Government, may be directly applicable, if a statute provides for their direct application and only if this application would not be contrary to the Constitution. This restriction refers to the constitutional requirement that only statutes may determine certain matters. As it is the case in Poland, a treaty norm, in order to be directly applicable, has to fulfil formal

60 Cf. P. Mikeš, 'Czech Courts and International Law' (2011) 2 Czech Yearbook of International Law, pp. 294-296.

61 Case Pl. ÚS 36/01 (Constitutional Court, 25 June 2002).

62 E.g. cases 2 Azs 343/2004 (Supreme Administrative Court, 4 August 2005); 9 Azs 23/2007 (Supreme Administrative Court, 14 June 2007).

63 Case 6 As 55/2006 (Supreme Administrative Court, 11 July 2007).

64 Cases of the Constitutional Court: I. ÚS 752/02 (15 April 2003); I. ÚS 733/05 (20 December 2006); III. ÚS 534/06 (3 January 2007).

65 Case III. ÚS 665/11 (Constitutional Court, 10 September 2013). 
and substantive conditions. A treaty/or a treaty norm, which is not directly applicable, may be still applied indirectly to interpret domestic law. ${ }^{66}$

Similarly as in the Polish legal system, customary international law could be applied either on the basis of the authorisation of a concrete act or under the general clause of Art. 1(2) of the Constitution. Cases adjudicated on the basis of customary law are, however, extremely rare. They concern citizenship, ${ }^{67}$ State succession, ${ }^{68}$ diplomatic immunity, ${ }^{69}$ State immunity, ${ }^{70}$ status of refugees and other persons. ${ }^{71}$ It is evident from this practice that the judges do not identify customary norms through reference to usus and opinio iuris. They do not even explain why they consider a specific rule a customary one or they base their determination on an opinion of only one scholar. ${ }^{72}$ Occasionally, the courts refer to norms of the treaties codifying customary law as customary norms for a sole purpose only: to underline their exceptional nature (e.g. norms of the Refugee Conventions).

66 E.g. the Supreme Administrative Court found the Aarhus Convention on Access to Information, Public Participation in Decision-making and Access to Justice in Environmental Matters not self-executing, however, it interpreted relevant domestic law as far as possible in concordance with the Convention: Cases 1 Ao 1/2006 (18 July 2006), 2 As 12/2006 (29 March 2007), 1 As 39/2006 (14 June 2007), 1 As 13/2007 (29 August 2007).

67 Cases of the Constitutional Court: Pl. ÚS 9/94 (13 September 1994) on the State power to grant citizenship under international law, IV. ÚS 580/06 (3 April 2007) on discrimination regarding granting of citizenship, II. ÚS 120/2000 (31 May 2000) on military service of a person holding dual citizenship.

68 Cases of the Constitutional Court: II. ÚS 214/98 (30 January 2001) on succession of the Czech Republic to the international obligations of former Czechoslovakia, I. ÚS 420/09 (3 June 2009) on succession to treaties between former USSR and Czechoslovakia.

69 Cases 11 Tcu 95/2003 (Supreme Court, 17 July 2003) on privileges and immunities of a person holding diplomatic passport but not being a member of a diplomatic mission, 11 Tcu 167/2004 (Supreme Court, 16 December 2004) on privileges and immunities of a member of a wider royal family on private trip, I. ÚS 173/04 (Constitutional Court, 4 May 2004) on a duty of an ambassador of the Sovereign Order of the Knights of Malta to serve as witness in a criminal proceedings.

70 In case 21 Cdo 2215/2007 (Supreme Court, 25 June 2008) on employment in Polish embassy in Prague, the Court briefly described the historical development of State immunity referring to the book of Czech scholar J. Malenovský and the Report of the Working Group on Jurisdictional Immunities of States and Their Property (UN Doc. A/CN.4/L.576, Annex at p. 58). The Court concluded that Poland had not acted as a sovereign (de jure imperii). Acta de jure gestionis are not covered by State immunity. The Supreme Court confirmed its understanding of the exception to State immunity in 30 Cdo 2594/2009 (24 March 2011) on non-admission to the readings held at the Austrian Cultural Institute in Prague.

71 Cases of the Supreme Administrative Court: 9 Azs 23/2007 (14 June 2007); 1 Azs 40/2007 (19 September 2007); 6 Azs 215/2006 (24 October 2007); 5 Azs 28/2008 (13 March 2009).

72 P. Mikeš, 'Country Report Czech Republic', para. III.2. 


\subsection{Deference to International and Foreign Courts Decisions}

\subsubsection{General Remarks}

Since the ECHR and the decisions of the ECtHR acquired constitutional status in the Czech Republic, ${ }^{73}$ the Constitutional Court often relies on the Convention and often finds Czech law or Czech courts decisions contrary not only to the Constitution but also to the Convention. ${ }^{74}$ In these cases the Court looks to the decisions of the ECtHR to support its own argumentation (concurring dialogue). However, there are many, especially earlier judgments, where the case law is only briefly or superficially mentioned. The same refers to ordinary or administrative courts.

Exceptionally, the Czech courts refer to other international courts decisions than the ECtHR. Mikeš points to the judgment of the Supreme Administrative Court in which the court discussed the decisions of the International Criminal Tribunal for the Former Yugoslavia (ICTY), the International Criminal Tribunal for Rwanda (ICTR), the International Court of Justice, the opinions of the International Committee of the Red Cross, and the decision of the Special Court for Sierra Leone in order to define the term 'internal armed conflict' in the Czech Asylum Act. ${ }^{75}$

Sometimes the courts, mostly the Constitutional Court, look up to the decisions of foreign courts for guidance in interpreting domestic law or to determine the standard of protection of certain rights. ${ }^{76}$ The citation is usually very short and often not direct but through literature that analyses foreign jurisprudence. ${ }^{77}$

73 Case I. ÚS 310/05 (Constitutional Court, 15 November 2006).

74 Cf. recent decisions of the Constitutional Court e.g. 1 Ús 860/1520 (27 October 2015) on expulsion of a foreigner and ill-treatment; 3 ÚS 1136/13 (8 December 2015) on indirect discrimination of Roma children - special schools; I. ÚS 2482/13 (26 May 2014) on joint custody; II. ÚS 3626/13 (18 January 2016) on the right to effective investigation in cases of human trafficking. Cf. P. Mikeš (n. 61), p. 296.

75 Case 5 Azs 28/2008 (Supreme Administrative Court, 13 March 2009). P. Mikeš, 'Country Report Czech Republic', para. II.6.

76 For a general overview see: Bobek M., Comparative Reasoning in European Supreme Courts (Oxford University Press 2013) 152-173.

77 P. Mikeš, 'Country Report Czech Republic', para. II.6., gives following examples. In case Pl. ÚS 19/93 (Constitutional Court, 21 December 1993): "From among the European judicature, we can refer to the same point of view of the Federal Constitutional Court of the FRG, which in 1969 ruled that the prohibition on the retroactivity of statutes did not apply to the statute of limitations: the subsequent designation of criminality or of a higher possible punishment fall under this prohibition, but not the limitation of actions, governing the period of time during which an act which is declared to be criminal may be prosecuted and leaving the criminality of an act unaffected. (Volume 25, page 269 and following, Collection of Decisions)." In case I. ÚS 453/03 (11 November 2005): "The requirement that the critic himself prove the claimed facts is a European constitutional standard (e.g. decision of the House of Lords of 28 October 1999 in the matter Reynolds v Times News Papers Limited, or the decision of the 
Recently the analysis of foreign judgments seems to be more insightful, e.g. in case concerning the producers of removable energy. ${ }^{78}$ There the Court referred to the jurisprudence of the courts in Germany, Poland, Spain, Italy, Austria, Croatia and the United States of America. Another example is the judgment of the Supreme Administrative Court in which the Court discussed thoroughly the jurisprudence of the ICJ, ICTY, ICTR, CJEU and domestic courts of the United Kingdom, Canada, New Zeeland, and the United States of America i.a. to interpret Art. $1 F(c)$ of the Geneva Convention Relating to the Status of Refugees and the possibility to exclude a refugee seeker from protection if he had been guilty of acts contrary to the purposes and principles of the United Nations. In the mentioned case the asylum seeker informed in 1980s Cuban authorities of suspicious activities of other Cubans living in Czechoslovakia. ${ }^{79}$

The Czech judges quote mostly the German Constitutional Court but there are also many references to the Polish Constitutional Court, as e.g. in cases concerning wages of judges, ${ }^{80}$ to the Austrian Constitutional Court, ${ }^{81}$ or to the Supreme Court of the United States. ${ }^{82}$ The Constitutional Court sometimes refers to the jurisprudence of the Slovak Constitutional Court, e.g. in the judgment on the judicial review of security clearances in which the Court studied carefully also the case law of the ECtHR and of the Polish Constitutional Court. ${ }^{83}$

German Constitutional Court (BVerfG) of 3 June 1980, 1 BvR 797/78 in the case of Böll, which is also confirmed by the case law of the European Court of Human Rights - the ECHR - e.g. decision of the Grand Chamber of 17 December 2004 in the matter Pedersen and Badsgaard v Denmark)." In case Pl. ÚS 19/98 (3 February 1999) the Constitutional Court referred to two decisions of the German Constitutional Court on refusal of mandatory military service and civilian alternative service. In case 23 Cdo 888/2011 (31 January 2013), the Supreme Court briefly referred (three sentences) to two judgments of the Austrian Supreme Court and the German Supreme Court on interpretation of Art. 13 of CMR Convention, excerpts of which were published in Czech commentary to the CMR Convention.

78 Case Pl. ÚS 17/11 (Constitutional Court, 15 May 2012).

79 Case 6 Azs 40/2010-70 (Supreme Administrative Court, 29 March 2011). Mikeš P., 'Country Report Czech Republic', para. VIII.3.

80 Cases of the Constitutional Court: Pl. ÚS 11/04 (26 April 2005); Pl. ÚS 34/04, Pl. ÚS 43/04 and Pl. ÚS 9/05 (passed on the same day, 14 July 2005), Pl. ÚS 33/11 (3 May 2012), Pl. ÚS 28/13 (10 July 2014).

81 E.g. case 8 Ob 657/87 (Supreme Court, 28 June 1988).

82 E.g. cases of the Constitutional Court: I. ÚS 367/03 (15 March 2005) on freedom of speech, Pl. ÚS 17/11 (15 May 2012) on retroactivity of taxation of solar power plants, Pl. ÚS 39/01 (30 October 2002) on sugar quotas.

83 Case Pl. ÚS 6/02 (Constitutional Court, 27 November 2002) in which the Slovak court decision was only mentioned; for broader discussion see PI. ÚS 11/04 (26 April 2005). In case Pl. ÚS 33/11 (3 May 2012) the Court observed: "The comparative arguments include a reference to the case law of European constitutional courts. The Constitutional Court of the Polish Republic permits interference in judges' salaries only in a situation when the Polish Constitution forbids general indebtedness of a State [that is, a situation when the public debt exceeds $3 / 5$ of the annual gross domestic product (decision file no. K 12/03)]. The Constitutional Court of the Slovak Republic, in judgment file no. Pl. ÚS 12/05, pronounced unconstitutional 


\subsubsection{The Foreigner Requesting Asylum in a Transit Area Case}

The 2014 decision of the Czech Supreme Administrative Court concerning the possibility of expulsion of a foreigner who was kept by the police in a transit area is possibly one of the most interesting cases from the point of view of this study. The foreigner in question was heading for a connecting flight and allegedly had used the passport belonging to another person. When stopped, he asked for asylum. ${ }^{84}$ The answer whether such foreigner could be expelled relied on the interpretation of Art. 31(1) of the Geneva Convention relating to the Status of Refugees, which reads:

The Contracting States shall not impose penalties, on account of their illegal entry or presence, on refugees who, coming directly from a territory where their life or freedom was threatened in the sense of Article 1, enter or are present in their territory without authorisation, provided they present themselves without delay to the authorities and show good cause for their illegal entry or presence.

The Supreme Administrative Court analysed two judgments of the UK courts for clarification of the term 'present themselves without delay to the authorities'. The first was the decision of the High Court of Justice concerning the detention of foreigners having false passports. ${ }^{85}$ The UK Court found that the protection of Art. 31 of the Refugee Convention extends to those foreigners who applied for asylum after their detention if they had been detained during a trip to another country where they wanted to apply for asylum. The Czech Court explained that the High Court based its conclusion on the premise that the main purpose of the Convention is to provide protection to refugees. Foreigners are basically allowed to choose the country where they want to seek protection; they cannot be deprived of this right just because they were detained during a short stop in the trip. ${ }^{86}$ The second one was the decision of the House of Lords ${ }^{87}$ in which the UK Court

of a statute (statutes) that for several years (2003-2006) postponed the entry into effect of a statute under which judges were entitled to remaining salary. In the opinion of that Constitutional Court, with reference to the principle of legitimate expectation, clarity, stability, and legal certainty, arising from the general principle of a state governed by the rule of law, it is not possible to speak of measures being 'temporary' if they last several years. These arguments were also used by the Constitutional Court of the Latvian Republic (file no. 2009-11-0), in an economic situation substantially worse than in our country, and in a situation where the relationship of a judge's salary at the beginning of his career and the average salary showed a more positive trend than in the Czech Republic [per the report from the Council of Europe - the European Commission for the Efficiency of Justice (CEPEJ) 2010 - appendix no. 8]."

Case 9 Azs 107/2014-43 (Supreme Administrative Court, 29 May 2014).

85 29 July 1999), EWHC Admin 765.

86 Case 9 Azs 107/2014-43 (Supreme Administrative Court, 29 May 2014) para. 25.

87 R v Asfaw (House of Lords, 21 May 2008). 
carefully examined the drafting history and the function of Art. 31 of the Convention and observed that the drafters of the Convention did not expect the massive development of air transport (refugees were originally only those persons who met the definition of a refugee as a result of events occurring before 1 January 1951) and could not have foreseen the difficulties associated with transfers during international flights. It is therefore necessary to ensure the protection of Art. 31 also to those foreigners who were detained in the transit country in order to enable them to continue their journey to the destination country where they intended to apply for asylum. ${ }^{88}$ The Czech Supreme Administrative Court concurred with the opinion of both courts.

The case is interesting also on account of the Supreme Administrative Court observations on judicial dialogue. The Court noted that nowadays when interpreting treaties more and more frequently the courts look for inspiration to the decisions of the courts of other contracting parties. It is even required by the basic principle of interpretation enshrined in Art. 31(1) VCLT that the parties to a treaty should give the same meaning to the terms of the treaty and apply them uniformly. Thus, if a high court of a State party to a given treaty interprets certain provisions of a treaty, the courts of another State party should take it into account, provided that they know about it. This is especially true when the conclusions of high courts of another State party to a given treaty are based on reasonable interpretation of the relevant treaty provisions.

\subsubsection{A Dissenting Dialogue}

The Czech courts sometimes disagree with the opinions of foreign or international bodies. For instance in several judgments the Constitutional Court refused to follow the Human Rights Committee decisions against the Czech Republic, invoking the ECtHR case law on the same issues or applied the Human Rights Committee's own jurisprudence on discrimination but reaching a result different to that the Committee itself had reached. ${ }^{89}$ The cases seem to illustrate common practice of not precise but simplified, general references or quite free accommodation of the ruling to the needs of the domestic court argumentation.

The cases concerned sensitive issues of recovery of the property confiscated by the communist government. In the decision of $1997^{90}$ the Constitutional Court found Extrajudicial Rehabilitation Act (Law no. 87/1991) compatible with the Constitution and the Czech Charter on Human Rights which was contrary to the findings of the HRC in Šmunek et. al $v$ The Czech Republic ${ }^{91}$ and Adam

88 Case 9 Azs 107/2014-43 (Supreme Administrative Court, 29 May 2014) para. 26.

89 Cf. Final Report on the Impact of Findings of the United Nations Human Rights Treaty Bodies, International Law Association, Berlin Conference (2004) paras 51-56.

90 Case Pl. ÚS 33/96 (Constitutional Court, 4 June 1997).

91 Simunek, Hastings, Tuzilova and Prochazka $v$ The Czech Republic, Communication No. 516/1992 (Human Rights Committee, 19 July 1995). 
$v$ The Czech Republic. ${ }^{92}$ In line with this Act the right to restitution of property expropriated by the communist regime was granted only to Czech citizens. The HRC had concluded that the differentiation between non-citizens and Czech citizens in the legislation was arbitrary and infringed upon the prohibition of discrimination under Art. 26 ICCPR. The Constitutional Court argued that in analogous cases the European Commission on Human Rights had come to different conclusions. These references, however, are not compelling since the Constitutional Court indicated the decisions on admissibility in which the Commission had not examined the violation under Art. 14 ECHR - the prohibition of discrimination..$^{93}$ The Constitutional Court invoked as well the HRC opinion in Zwaan de Vries $v$ Netherland $^{94}$ for authority that a differentiation in treatment, if based on reasonable grounds, does not necessarily have to violate Art. 26 ICCPR. Consequently, the Court considered the restriction in question to be justified.

In the decision of $1998^{95}$ the Constitutional Court adjudicating on the provisions of the same Act which made the restitution of property contingent upon the relevant nationalisation having taken place between 25 February 1948 (the date of the Communist take-over) and 1 January 1990, referred to the HRC opinion in Šimuinek et. al v The Czech Republic ${ }^{96}$ as holding that the national legal order could not differentiate between former and later victims of nationalisation (though the opinion said nothing on the issue). The Court emphasized that the setting of the time limits had an objective and reasonable basis, and any other approach could lead to a chain of restitution claims. ${ }^{97}$

In the 2003 decision the Constitutional Court mentioned the views of the $\mathrm{HRC}$ only in general terms and referred to the "numerous decisions of the control organs" existing under international human rights instruments on principle of equality. The Court held that the preferential treatment of miners in the

92 Josef Frank Adam v The Czech Republic, Communication No. 586/1994 (Human Rights Committee, 23 July 1996).

93 Cases of the European Commission on Human Rights: Brežný v Slovak Republic, App. no. 23131/93 (4 March 1996); Pezoldová v Czech Republic, App. no. 28390/95 (11 April 1996); Nohejl v Czech Republic, App. no. 23889/93 (13 May 1996); Jonas v Czech Republic, App. no. 23063/93 (13 May 1996).

94 Zwaan de Vries v Netherlands, Communication No. 182/1984 (Human Rights Committee, 9 April 1987) para. 13.

95 Case Pl. ÚS 45/97 (Constitutional Court, 25 March 1998).

Simunek, Hastings, Tuzilova and Prochazka v The Czech Republic, Communication No. 516/1992 (Human Rights Committee, 19 July 1995).

97 Cf. the other judgments of the Constitutional Court on constitutionality of the precondition of holding the Czech citizenship for the restitution of nationalised property of those persons whose property had been expropriated under the communist regime on the basis of criminal proceedings and who had been rehabilitated by the courts on the basis of the Act on Judicial Rehabilitation of 1991. See e.g. case Pl. ÚS 24/98 (22 September 1999) on the limited to citizenship eligibility for restitution of the land by the Act No. 229/1991 Coll. on the Regulation of the Property Relations to Land and Other Agricultural Property, case Pl. ÚS 9/99 (6 October 1999). 
legislation is justified, since for years they had performed work, which was physically and mentally extremely demanding and conducted under very harsh conditions.98

The most famous Czech example of a dissenting judicial dialogue is the Constitutional Court decision on Slovak pension rights concerning the obligations in international law and EU law. ${ }^{99}$ The case was broadly commented upon, ${ }^{100}$ also in this volume (see the contribution by Skomerska-Muchowska). The commentators underline the internal conflict between the Supreme Administrative Court and the Constitutional Court, which led to a curious judgment of the latter, based on emotions rather than reason, proclaiming disobedience towards the CJEU preliminary ruling. Ironically, the CJEU decision to a large extent supported previous findings of the Constitutional Court. The case provides an example of a situation where the occurrence of a horizontal dialogue (the discourse between domestic courts) may subsequently lead to a vertical dialogue between international and domestic courts.

98 Case Pl. ÚS 15/02 (Constitutional Court, 21 January 2003).

99 Slovak Pensions, Pl. ÚS 5/12 (Constitutional Court, 31 January 2012).

100 A. Dyevre, 'Domestic Judicial Non-Compliance in the European Union: A Political Economic Approach' (2013) 2 LSE Law, Society and Economy Working Papers. pp. 1-34; R. Zbíral, 'A Legal Revolution or Negligible Episode? Court of Justice Decision Proclaimed Ultra Vires' (2012) 49 Common Market Law Review, p. 1457; J. Komárek, 'Czech Constitutional Court Playing with Matches: The Czech Constitutional Court Declares a Judgment of the Court of Justice of the EU Ultra Vires' (2012) 8 European Constitutional Law Review, p. 323; G. Anagnostaras, 'Activation of the Ultra Vires Review: The Slovak Pensions Judgment of the Czech Constitutional Court' (2013) 14(7) German Law Journal, pp. 959-973; P. Molek, 'The Court that Roared: The Czech Constitutional Court Declaring War of Independence against the ECJ' (2012) 6 European Law Reporter, pp. 162-170. Molek observes that: "After the ECJ's judgment in Marie Landtová, the Czech legal doctrine as well as practitioners interested in social security law were eagerly expecting the CCC's reaction. Accepting its own mistake in Czech-Slovak Agreement's interpretation and admitting that its previous case-law was discriminating against non-Czech EU citizens did not seem feasible. Nonetheless, the CCC could try to keep face while obeying the ECJ by distinguishing the new cases from its previous case-law, on the basis that it did not apply to cases in which a pension was granted after the Czech Republic had entered the EU. A second option would be to enter into a real dialogue with the ECJ treating it as an equal partner and thereby fulfilling the dream of constitutional pluralists of the mutual respect of courts at different levels. The CCC showed that there is 'a third way', this third option resembling a declaration of war of independence (or ignorance?) against the ECJ, forgetting that the Czech Republic limited its sovereignty, as the CCC would supposedly define it, voluntarily on 1 May 2004" (166). See also: K. Wójtowicz, Constitutional Courts and European Union Law (Wrocław 2014), p. 98. 


\subsubsection{The Slovak Pensions Rights Case - Horizontal and Vertical Dialogue}

The case was resolved against the background of dissolution of Czechoslovakia and unclear provisions of the Agreement between the Czech Republic and the Slovak Republic on social security of 29 October 1992 which determines the State that would be responsible for the payment of old age benefits corresponding to the periods of insurance under the previous legal regime. Pursuant to Art. 20 of the Agreement the applicable scheme and the authority with competence to grant old age benefits would be linked to the State of residence of the employer at the time of dissolution of Czechoslovakia. Consequently, Czechs whose employer had had residence in the Czech part acquired Czech old age pensions and Czechs whose employer had had residence in the Slovak part acquired Slovak old age pensions. Since Slovak pensions were significantly lower than Czech ones, the question arose whether they should not be supplemented by the Czech authorities to the level corresponding to that of other Czech citizens' pensions.

The Czech Social Security Administration, supported by the Supreme Administrative Court, adopted a rather literal interpretation of Art. 20 of the Agreement. ${ }^{101}$ People who were not satisfied with this approach addressed the Constitutional Court. The Constitutional Court (for the first time in the judgment of 2003) found that the right to adequate material security in old age and the principle of equality guarantee similar pensions to all Czech citizens. ${ }^{102}$ Therefore, Art. 20 of the Agreement must be applied in such a way that the amount of the retirement pension paid by the other contracting party be supplemented to be equivalent to the higher entitlement set by national legislation. ${ }^{103}$ In subsequent decisions the Constitutional Court concluded that the supplements are reserved only for Czech citizens residing on the Czech territory. ${ }^{104}$ The series of decisions found no acceptance on the part of the Supreme Administrative Court. In the opinion of this Court the supplements were incompatible with the Agreement and EU law and, in particular, with the Council Regulation 1408/71 on the application of social security schemes to employed persons moving within the Union. The Czech Constitutional Court rejected these arguments without having referred for a preliminary ruling to the CJEU, although the interpretation of EU law was also at stake. ${ }^{105}$ When the Supreme Administrative Court asked the CJEU for the ruling, the Constitutional Court warned that it is its interpretation of the Regulation that would prevail in the case at stake regardless of the ruling of the CJEU. The Constitutional Court held, furthermore, that suspending the proceedings before the administrative court to await the judgment

\footnotetext{
101 Case 6 Ads/2003 (Supreme Administrative Court, 23 February 2005).

102 Case II. ÚS 405/02 (Constitutional Court, 3 June 2003).

103 Case III. ÚS 252/04 (Constitutional Court, 25 January 2005).

104 Case I. ÚS 294/06 (Constitutional Court, 24 June 2008) paras 25, 33.

105 Case Pl. 4/06 (Constitutional Court, 20 March 2007).
} 
of the Luxemburg Court violated the right to a fair trial. ${ }^{106}$ In C-399/09 Landtová, the CJEU held that the payment by the Czech Republic of a supplement to old age benefit is not contrary to EU law, however, it is contrary to EU law to pay it solely to Czech nationals residing on the territory of the Czech Republic. ${ }^{107}$ The Court added that it does not necessarily follow, under EU law, that persons benefiting from supplementary social protection (satisfying these two requirements) should be deprived of it. ${ }^{108}$

Whilst the Parliament adopted an act, which excluded the future payment of supplements, the reaction of the courts to the CJEU decision is rather surprising. ${ }^{109}$ The Supreme Administrative Court which asked for a preliminary ruling instead of awarding Mrs. Landtová with the supplement held that as the Constitutional Court created this special supplement in violation of EU law (also by not referring the case to the CJEU), the decisions of the Constitutional Court cannot be binding on the Supreme Administrative Court. The only possibility to resolve the case at stake lied in the Constitutional Court finding relevant provisions of EU law incompatible with the Constitution. In the decision, the Supreme Administrative Court referred as well to the judgments of the Constitutional Court (cases Pl. ÚS 50/04 and Pl. ÚS 19/08), in which the Constitutional Court concurred with the Solange doctrine developed by the judgments of the German Constitutional Court and emphasized that the Constitutional Court has the undoubted authority, not questioned by anyone at the national level, arising from its role as the guardian of the constitutionality and the sovereignty of the Czech Republic. The Constitutional Court is, therefore, free to review again a disputed legal issue, which had been the subject matter of a preliminary ruling of the CJEU. Such a judgment would be directly binding as a precedent both for the Czech pension insurer, and for all ordinary courts. ${ }^{110}$

The Constitutional Court, provoked by the Supreme Administrative Court, answered with a highly emotional, 'revolutionary' judgment, finding for the first time in the history of the EU, the ruling of the CJEU to be ultra vires. ${ }^{111}$ Without

106 Case III. ÚS 1012/10 (Constitutional Court, 12 August 2010).

107 C-399/09 Marie Landtová v Česká správa socialního zabezpečení (CJEU, 22 June 2011) paras 40 and 54 .

108 Ibidem, para. 54.

109 Para. 106a of the Act No. 155/1995 Coll., as amended by the Act No. 428/2011 Coll.

110 Case 3 Ads 130/2008-204 (Supreme Administrative Court, 25 August 2011).

111 The Constitutional Court held that: "[f]ailure to distinguish the legal relationships arising from the dissolution of a state with a uniform social security system from the legal relationships arising for social security from the free movement of persons in the European Communities, or the European Union, is a failure to respect European history, it is comparing things that are not comparable" and "that in that case there were excesses on the part of a European Union body, that a situation occurred in which an act by a European body exceeded the powers that the Czech Republic transferred to the European Union under Art. 10a of the Constitution; this exceeded the scope of the transferred powers, and was ultra vires." Slovak Pensions, Pl. ÚS 5/12 (Constitutional Court, 31 January 2012). 
entering into deep discussion of the judgment, we confine ourselves to the expression of the doubts concerning the reasoning of the Constitutional Court. The Court seems to have based its judgment on a false assumption that the situation at stake is purely internal, i.e. that EU law is not applicable to the legal relations regulated by the Agreement between Slovakia and the Czech Republic. In fact, however, the argumentation should be contrary, since the Agreement became a part of EU law following the accession of both States to the EU. It was listed in the third Annex of the Regulation 1408/71 as still applicable but interpreted in accordance with the general principles of EU law (there is another Annex in the Regulation enumerating agreements that may introduce measures of unequal treatment of certain groups, the Czech-Slovak Agreement is not listed there). For the Constitutional Court this only means that the Agreement falls entirely outside the scope of the Regulation.

The case has some other aspects as well. One is an evident opposition of the government to the Constitutional Court judgments (before the CJEU the government clearly stated that the Constitutional Court violated EU law). The other is a doubtful behaviour of the CJEU whose judicial office returned the statement of the Constitutional Court sent to the CJEU explaining the Constitutional Court standing on the issues under the consideration of the European court. The note of the CJEU reminded the Constitutional Court that "pursuant to established customs, members of the ECJ do not correspond with third persons regarding cases that have been submitted to the ECJ." 112

The Constitutional Court ruling certainly is not legally compelling. It illustrates a mistaken use of ultra vires argument and will not serve as a precedent. But, on the other hand, the CJEU, having probably in mind to force constitutional courts to ask for preliminary rulings instead of sending informal letters to the Court, missed the opportunity to keep friendly relations with the Czech Court. All this shows that judges are only humans and they are subject to competition, and are neither devoid of emotions nor of judicial egoism. ${ }^{113}$

112 As recorded by the Constitutional Court, ibidem.

113 G. Anagnostaras, 'Activation of the Ultra Vires Review: The Slovak Pensions Judgment of the Czech Constitutional Court' (2013) 14 German Law Journal, pp. 959-973, 972. 


\section{Hungary}

\subsection{Dualistic Approach to International Law}

Similarly as in the other countries under our review, the Hungarian Constitution refers to international law. ${ }^{114}$ Since 1 January 2012 Hungary has had a new Fundamental Law. ${ }^{115}$ The new Constitution replaced the Constitution of 1949. ${ }^{116}$ Both acts contain similar provisions on international and EU law, especially as to their purpose and function. Article $\mathrm{Q}(2)$ of the Fundamental Law, which replaced Art. 7(1) of the Constitution of 1949 declares that in order to comply with obligations under international law, Hungary shall ensure that Hungarian law be in conformity with international law (the so-called 'harmony clause'). Article $\mathrm{Q}(3)$ states that "Hungary shall accept the generally recognised rules of international law. Other sources of international law shall become part of the Hungarian legal system by promulgation in legal regulations." Adjudicating in the context of the 1949 Constitution, the Constitutional Court underlined that Art. 7 regulates the relations between national and international law, and that it is a special constitutional provision that follows from the principle of the rule of law. ${ }^{117}$ In the opinion of the Constitutional Court, this also means that the participation of the Republic of Hungary in international community is a constitutional imperative for domestic law. In the 2013 decision, which confirmed the relevance of its previous case law based on the 1949 Constitution to the present context, the Constitutional Court explained that every obligation of Hungary under international law is an 'assumed' or an 'undertaken' obligation. International law is a distinct legal system (dualistic approach) ${ }^{118}$ and has to be somehow introduced into domestic law. Article Q of the Constitution regulates the relations between the two systems. According to this provision, the universally recognised rules of international law are transformed into domestic law (assumed) in a general way by the Constitution, while "other sources of international law" need to

114 For general overview, see: N. Chronowski, T. Drinóczi, I. Ernszt, 'Hungary', [in:] D.L. Shelton (ed.), International Law and Domestic Legal Systems: Incorporation, Transformation, and Persuasion (Oxford University Press 2011), pp. 288-327. On judicial dialogue in Hungary see e.g. K. Kovics, 'Cooperative Decision-making: The Relation between Hungary and Strasbourg' (2011) 5(2) Vienna Journal on International Constitutional Law, pp. 188-199; L. Blutman, N. Chronowski, 'Hungarian Constitutional Court: Keeping Aloof from European Union (2011) 5(2) Vienna Journal on International Constitutional Law, pp. 329-348; N. Chronowski, E. Csatlós, 'Judicial Dialogue or National Monologue? The International Law and Hungarian Courts’ (2013) 1 ELTE Law Journal, pp. 7-28.

115 The Fundamental Law of Hungary was adopted on 25 April 2011.

116 The Act XX of 1949 on the Constitution of the Republic of Hungary as revised in 1989-1990.

117 Case 7/2005 (III. 31.) AB (Constitutional Court, 29 March 2005).

118 See N. Chronowski, E. Csatlós (n. 115) 9, 12. 
be transformed individually with a use of special legal acts. The Constitutional Court observed that:

3.2. According to Article Q) para. (3) of the Fundamental Law, Hungary shall accept the generally recognised rules of international law. The first part of Article 7 para. (1) of the previous Constitution contained a rule with the same essential content, and the Constitutional Court attributed special importance to it, with consequences on the interpretation of the law as well: "The first sentence of Article 7 para. (1) of the Constitution, according to which the legal system of the Republic of Hungary accepts the generally recognized rules of international law, states that the generally recognized rules are part of Hungarian law, even without separate (further) measure of transformation. An act of general transformation - one without a definition or enumeration of those rules - was performed by the Constitution itself. According to it, the generally recognized rules of international law are not part of the Constitution but they are assumed obligations. The fact that the assumption and transformation is contained in the Constitution does not affect the hierarchical relationship of the Constitution, international and domestic law. [...] Article 7 para. (1) of the Constitution also means that by the Constitution's order, the Republic of Hungary participates in the community of nations; this participation, therefore, is a constitutional command for domestic law. It follows therefrom that the Constitution and domestic law must be interpreted in a manner whereby the generally recognized international rules are truly given effect" [Decision 23/1993 (X. 13.) AB, ABH 1993, 323, 327]. ${ }^{119}$

119 Case $1 / 2013$ (I. 7.) AB on the unconstitutionality of certain provisions of Act on Election Procedure (Constitutional Court, 4 January 2013) para. III.3.2. The Decision 23/1993 (X. 13.) AB cited in this judgment belongs to fundamental judgments of the Hungarian Constitutional Court on the relationship between international and Hungarian law, between international criminal law and national criminal law, and the non-applicability of statutory limitations to international crimes under customary and treaty law. The Constitutional Court was requested by the President to review the constitutionality and compatibility with international law of a law enacted by the Parliament in order to extend the non-applicability of statutory limitations to offences committed during the 1956 revolution. The Court concluded that the Constitution requires the non-applicability of statutory limitations to be used only to offences, which were not subject to statutory limitations under the law in force at the time the offences were committed, unless those offences were regarded as war crimes or crimes against humanity under international law. In the latter case, the application of Hungarian law would be precluded. Grave breaches of the Geneva Conventions and violations of common Article 3, as crimes against humanity, were not subject to statutory limitations under the New York Convention of 1968 and thus precluded the application of statutory limitations under Hungarian law in force at the time when the offences were committed. Finally, the Constitutional Court held that provisions under its review were unconstitutional. In 1996, the Constitutional Court dealt with an amended law. The Court held that the law was unconstitutional because it was contrary to international law (case 36/1996 (X. 13.) AB, 4 September 1996). Cf. T. Hoffman, 'Trying Communism through International Criminal Law? The Experiences of the Hungarian Historical Justice Trials', [in:] K.J. Heller, G. Simpson, The Hidden Histories of War Crimes Trials (Oxford University Press 2013), pp. 229-247. 
As the generally recognised rules of international law are directly transformed, they are equal to constitutional norms in the hierarchy of sources of Hungarian law and even prevail over the Constitution since the Constitution has to be interpreted in concordance with these rules. ${ }^{120}$

The concept of the generally recognised rules of international law encompasses customary international law and general principles of law. ${ }^{121}$ There are no examples of the determination of customary international law by reference to State practice and opinio iuris by Hungarian courts. Chronowski and Csatlós observed that customary international law is rarely applied and if so, the Constitutional Court relies on codifying treaties. ${ }^{122}$

It is interesting to note that under the heading of the generally recognized principles of international law, the Constitutional Court referred to jus cogens. It defined the term according to the Vienna Convention on the Law of Treaties. ${ }^{123}$ Adjudicating upon the constitutionality of the draft amendment of the Criminal Code and its conformity with international norms relating to the prescription of crimes committed in violation of common Articles 2 and 3 of the 1949 Geneva Conventions, the Constitutional Court derived the legal basis for punishability of crimes against humanity and war crimes without time limit from the fact that the prohibition of these crimes is considered to be jus cogens as they threaten the whole mankind. The Court emphasised that "national law shall not be applied as against an explicit peremptory norm of international law contrary to it." 124 The Constitutional Court enumerated as jus cogens also the principles nullum crimen sine lege ${ }^{125}$ and pacta sunt servanda. ${ }^{126}$

120 Case 53/1993 (X. 13.) AB (Constitutional Court, 13 October 1993).

121 The Constitutional Court explained that the term "generally recognised rules of international law" covers universal customary international law, peremptory norms (jus cogens) and general principles of law recognized by civilized nations - case 30/1998 (VI. 25.) AB (Constitutional Court, 22 June 1998). It also observed that "[t]he constitutional criteria of a democratic State under the rule of law are at the same time constitutional values, principles and fundamental democratic freedoms enshrined in international treaties and accepted and acknowledged by communities of democratic States under the rule of law, as well as the ius cogens, which is partly the same as the foregoing. As appropriate, the Constitutional Court may even examine the free enforcement and the constitutionalization of the substantial requirements, guarantees and values of democratic States under the rule of law" (case 45/2012 (XII. 29.) $A B$ (28 December 2012) on the unconstitutionality and annulment of certain provisions of the Transitional Provisions of the Fundamental Law of Hungary, para. IV.7). In case 5/2001 (II. 28) AB of 12 March 2001 the Constitutional Court qualified the provisions of the UN Charter as reflecting generally accepted principles of international law. Cf. M. Dezső et al., Constitutional Law in Hungary (Kluwer Law International 2010), p. 57.

122 N. Chronowski, E. Csatlós (n. 115), pp. 19-20.

123 Case 30/1998 (VI. 25.) AB (Constitutional Court, 22 June 1998). Cf. case 45/2012 (XII. 29.) AB (Constitutional Court, 28 December 2012).

124 Case 53/1993 (X. 13.) AB (Constitutional Court, 13 October 1993).

125 Ibidem.

126 Case 4/1997 (I. 22.) AB (Constitutional Court, 22 January 1997). 
Other sources of international law (the most obvious ones are treaties ratified or approved by the Government $)^{127}$ have to be separately transformed by the appropriate legal act (promulgated) into domestic law. ${ }^{128}$ For example, the Vienna Convention on the Law of Treaties was promulgated in Law: Decree 12 of 1987, the ECHR, on the other hand was promulgated in Act XXXI of 1993. Their provisions can be directly applicable. The courts recognised in practice that promulgation is a formal condition of direct applicability while the substantive condition is whether the rights, duties and sanctions enshrined in the provisions of a treaty are sufficiently defined for judges to apply them in a case at hand. ${ }^{129}$ The position of a treaty in the hierarchy of legal acts depends on the legal character of the transformation act (whether it is an act of the Parliament or of the Government). ${ }^{130}$ These rules apply to all treaties, including to the treaties containing self-executing norms. Whether the norm is self-executing, that is whether it may be applied in Hungarian law without separate implementing norm, is a question of interpretation. ${ }^{131}$

Article E(1) and (2) of the Fundamental Law (Art. 6(4) of the Constitution of 1949) provides for Hungarian participation in the European cooperation, including the membership in the EU. What is interesting from our perspective is the novel Art. E(3), which authorizes the application of EU law in the domestic context. The formula is rather general. The provision states that EU law "may stipulate a generally binding rule of conduct." There exists no other provision on application of EU law in domestic legal system. It is understood that the rules of primacy of application of EU law or the rights and duties of domestic courts stem from the EU founding treaties and they should be applied as such. ${ }^{132}$

The Fundamental Law has not solved the uncertainties concerning international law, moreover, certain constitutional provisions, permitting exceptions to democracy, the rule of law and the protection of fundamental rights, could come

127 The rules on procedure concerning the conclusion, modification, suspension, termination of treaties etc. are regulated by the Act L of 2005 (2005. évi L. törvény a nemzetközi szerződésekkel kapcsolatos eljárásról).

128 Under Art. 10(1) of the Act $L$ of 2005 the promulgating act should contain all the relevant data for application of a treaty, e.g. the date of coming into force, reservations, declarations, statements, indication of the organ which is responsible for the execution, and, if necessary, amendments to existing Hungarian regulations or any other implementing provisions necessary to harmonize international and national law.

129 E.g. case 7/2005 (III. 31.) AB (Constitutional Court, 29 March 2005); 116/B/2006 AB (Constitutional Court, 2007) ABH 2007, 1936, 1938; Fejer County Court 25.P.22.432/2008/61; 25.P./2008/80. Cf. case 116/B/2006 AB (Constitutional Court) ABH 2007, 1936, 1938.

130 The Constitutional Court did not declare the priority of treaties over domestic law but only held that international law is not to be adjusted to the conditions of domestic law, but rather domestic law should be adjusted to comply with international law. Case 53/1993 (X. 13.) AB (Constitutional Court, 13 October 1993).

131 Case 7/2005 (III. 31.) AB (Constitutional Court, 29 March 2005). Cf. M. Dezső et al., Constitutional Law in Hungary (Kluwer Law International 2010), p. 56.

132 N. Chronowski, E. Csatlós (n. 115), p. 10. 
into conflict with international obligations. ${ }^{133}$ Especially, the Fourth Amendment to Fundamental Law of $2013^{134}$ was highly criticized, e.g. by the Venice Commission, ${ }^{135}$ the European Parliament and the European Commission. ${ }^{136}$ The Amendment i.a. restricts the power of the Constitutional Court, enables the criminalization of homelessness, restricts the definition of family, and upholds the arbitrary registration process for churches. It has to be emphasized that the Fourth Amendment excluded the application of the previous case law of the Constitutional Court to the new Constitution. Art. 19 of the Fourth Amendment reads: "[d]ecisions and their reasoning of the Constitutional Court prior to the coming into force of the Fundamental Law cannot be used for interpreting the Fundamental Law." Furthermore, under Art. 24(3)(c) of the Fundamental Law the conflict between a domestic provision and an international treaty need not be solved by the annulment of the former. The Constitutional Court is not obliged to annul the domestic legislation (only 'may'). The provision certainly weakens the effects of the treaties and gives rise to doubts as to the harmony between two legal orders. Much depends thus on judges of the Constitutional Court and judges of other courts. It is up to them to continue the tradition or to develop new interpretations.

In fact, the Constitutional Court gave the first signals of continuity in its judgment of 2012. The Court observed that "[i]n the new cases the Constitutional Court may use the arguments included in its previous decision adopted before the Fundamental Law came into force in relation to the constitutional question ruled upon in the given decision, provided that this is possible on the basis of the concrete provisions and interpretation rules of the Fundamental Law, having the same or similar content as the provisions included in the previous Constitution." ${ }^{137}$ According to this decision, the Constitutional Court's statements made on

133 Ibidem.

134 The Fourth Amendment was adopted on 11 March 2013, entered into force on 1 April 2013. It was the response to the Constitutional Court Decision 45/2012 (XII. 29.) AB (n. 1) which invalidated all the provisions of the Transitional Provisions of Fundamental Law not having the character of provisional regulations. The Fourth Amendment incorporated majority of the quashed provisions into the Constitution.

135 Opinion 720/2013 of the Venice Commission on the Fourth Amendment of the Fundamental Law of Hungary, Strasbourg 17 June 2013, <http://www.venice.coe.int/webforms/documents/?pdf=CDL-AD\%282013\%29012-e> (access: 17 June 2013).

136 On constitutional crisis in Hungary see A. von Bogdandy, P. Sonnevend (eds), Constitutional Crisis in the European Constitutional Area, Theory, law and Politics in Hungary and Romania (Hart Publishing 2015) 5; R. Uitz, 'The illusion of the constitution in Europe: The Hungarian Constitutional Court after the Fifth Amendment of the Fundamental Law', [in:] J. Bell, M.-L. Paris (eds), Right-Based Constitutional Review: Constitutional Courts in a Changing Landscape (Edward Elgar Publishing 2016), pp. 374-408.

137 Case 22/2012 (V. 11.) AB on the interpretation of paras (2) and (4) of Article E) of the Fundamental Law (Constitutional Court, 'without specified date') paras 40-41. Confirmed in case $1 / 2013$ (I. 7.) AB on the unconstitutionality of certain provisions of Act on Election Procedure (Constitutional Court, 4 January 2013) para. III.4. 
the fundamental values, human rights and freedoms and on the constitutional institutions that have not been changed essentially by the Fundamental Law remain valid. In 2013 the Constitutional Court indicated that the obligations of Hungary that arise from international treaties, the EU membership, the generally recognized rules of international law and the fundamental principles and values compose such a coherent system that cannot be left out of consideration during the law-making process (including constitution-making) and the constitutional review of the Constitutional Court. ${ }^{138}$ Against this background, the literal interpretation of Art. 19 of the Fourth Amendment seems inaccurate. However, we cannot verify the practice of the Constitutional Court after the entry into force of the Fourth Amendment since the new decisions of the Constitutional Court are not available in English.

\section{2. 'International Legal Comparisons' of Hungarian Courts}

It seems that Hungarian courts broadly refer to international law instruments ${ }^{139}$ and this tendency will be probably retained despite present constitutional problems. As in the other EU countries, the European Convention of Human Rights is the most frequently invoked treaty. ${ }^{140}$ Naturally, when applying the Convention, the courts, even if not all of them, refer to the ECtHR case law and the decisions of foreign courts. Just as in other countries there is a difference in regularity and quality of references between the Constitutional Court and the other courts. ${ }^{141}$ The practice of the latter was found to be "neither unambiguous nor consistent" 142 (see also in this volume the contribution by Górski).

\subsubsection{The Abortion and the Status of a Foetus Case}

In order to illustrate the practice of inserting legal comparisons by the Hungarian courts, we would like to highlight three judgments of the Constitutional

138 Case 12/2013 (V. 24.) AB (Constitutional Court, 21 May 2013), cf. 13/2013 (VI. 17.) AB (Constitutional Court, 11 June 2013).

139 N. Chronowski, E. Csatlós (n. 115), pp. 7-28.

140 Cf. P. Sonnevend, 'Report on Hungary', [in:] G. Martinico, O. Pollicino (eds), The National Judicial Treatment of the ECHR and EU Laws, A Comparative Constitutional Perspective (Groningen: Europa Law Publishing 2010), p. 258.

141 J. Bóka, 'Use of the Comparative Method by the Hungarian Constitutional Court - Conceptual and Methodological Framework for an Ongoing Research Project', [in:] A. Badó, W.B. Detlev, J. Bóka, P. Mezei, Internationale Konferenz zum zehnjährigen Bestehen des Instituts für Rechtsvergleichung der Universität Szeged (Acta luridica Universitatis Potsdamiensis, Universitätsverlag Potsdam 2014), pp. 93-107. See in the same volume E. Csatlós, 'The Application of International Law as an Instrument of Interpretation in Hungary - The Practice of the Constitutional Court and Ordinary Courts in a Comparative Approach', <https://publishup. uni-potsdam.de/opus4.../S127-142_aiup01.pdf> (access: 25 September 2016), pp. 127-142.

142 N. Chronowski, E. Csatlós (n. 115), p. 17, 16. The authors quote the decisions refusing application of the ECtHR case law, decisions wrongly invoking cases or invoking cases only for decoration etc. (see e.g. 18). 
Court. The first decision, issued in 1998, concerns the highly controversial issues of abortion, the status of a foetus, the right to dignity and the right to life. ${ }^{143}$ To answer the question whether abortion should be permitted in exceptional situations the Court broadly discussed the ECHR and the case law of the European Human Rights Commission, foreign legislation and decisions of German, Polish and the United States courts. The Hungarian Court distanced itself from the Polish Constitutional Court judgment on the constitutionality of the Polish 1997 abortion law, ${ }^{144}$ borrowing instead in some respects from the US Supreme Court ${ }^{145}$ and the German Constitutional Court's decisions on abortion adopted between 1975 and 1993. ${ }^{146}$ Yet, in fact, the judgment is based on the assessment of the Hungarian legislation and the previous judgments of the Constitutional Court.

The Hungarian Court i.a. observed that the right to life and human dignity is ranked at the top in the hierarchy of constitutional fundamental rights. The State has an objective duty to protect life, which includes also that of a conceived individual human life. In other legal systems, as the Court noted, the special individual fundamental rights are distinguished as the human dignity of an unborn human life and the unborn man's own right to life. For example, the German Constitutional Court found that a foetus has its own individual right to life. ${ }^{147}$ However, this does not mean that a foetus can be declared a legal person (subject of law), since any special legal status not reaching the legal status of a human would practically offer only a relative protection to a foetal life. Furthermore, "among the rights to be weighed against the State's duty to give increased protection to foetal life,

143 Case 48/1998 (XI. 23.) AB (Constitutional Court, 18 November 1998). Cf. case 21/B/2008, $154 / 2008$ (XII. 15.) AB concerning the constitutionality of the Act of 2007 No. CLXXXIV on registered partnerships (Constitutional Court, 15 December 2008).

144 The Constitutional Court of Hungary indicated the case only by the date of the judgment: 5 May 1997. It seems that the Court meant the case K 26/96 (Polish Constitutional Court, 28 May 1997).

145 The judgment refers generally to the jurisprudence of the Supreme Court on the right to privacy as a constitutional ground for the right to abortion and mentions the recognition of the use of contraceptives falling under the right to privacy in Griswold v Connecticut 381 U.S. 479 (1965).

146 The German Constitutional Court Cases Schwangerschaftsabbruch I 1 BvF 1, 2, 3, 4, 5, 6/74 (25 February 1975) BVerfGE 39, 1 and Schwangerschaftsabbruch // 2 BvF 2/90 and 4, 5/92 (28 May 1993) BVerfGE 88, 203. For discussion of comparisons between Hungarian and German approach see Ch. McCrudden, 'Human Dignity and Judicial Interpretation of Human Rights' (2008) 19 European Journal of International Law, pp. 655-724. C. Dupré, Importing the Law in Post-Communist Transitions: The Hungarian Constitutional Court and the Right to Human Dignity (Oxford: Hart 2003).

147 Case 48/1998 (XI. 23.) AB (Constitutional Court, 18 November 1998) para. III.1.a. The Court referred to the German Constitutional Court decision Schwangerschaftsabbruch // 2 BvF 2/90 and 4, 5/92 (28 May 1993) BVerfGE 88, 203. 
the mother's right to self-determination - as a part of the right to human dignity is the most important one." 148

The Court concluded that a provision permitting abortion in case the pregnant woman is in a situation of a serious crisis is not unconstitutional. The reasoning is certainly grounded in the former decisions from other jurisdictions, but not identical with them. For example, by contrast to the German Constitutional Court's abortion decisions it does not link the woman's right to self-determination and the foetal right to life to the protection of human dignity. ${ }^{149}$

\subsubsection{The Election Rights Case - the Limits of International Comparisons}

The second example is the 2013 judgment of the Constitutional Court ${ }^{150}$ concerning the constitutionality of certain provisions of the Election Procedure Act. The decision is interesting from our perspective, since it explains the use of - as the Court called it - 'international legal comparison' in practice of the Court. Firstly, the Constitutional Court enumerated all previous decisions in which the method was applied ${ }^{151}$ and observed that "[t]he constitutionality of a specific legal institution in another country depends on the constitution of a given State, the fitting into the legal system, and on the historical and political background. Therefore, the Constitutional Court - though acknowledging that taking into account foreign experiences may help to evaluate certain regulatory solutions - does not consider the example of any foreign country in itself as a determining factor with regard to the review of constitutionality (compliance with the Fundamental Law)." 152 The Constitutional Court did not invoke any foreign judgments but referred broadly to the ECtHR case law. It started by general observance:

According to the electronic search engine (HUDOC) of the judicial practice of the European Court of Human Rights [...], 82 cases out of the 15 thousand judgements on the merit were connected to Article 3 of the Amending Protocol to the European Convention on Human

148 Ibidem, III.3.B.

149 S. Halliday, Autonomy and Pregnancy, A Comparative Analysis of Compelled Obstetric Intervention (Routledge 2016) 113.

150 Case $1 / 2013$ (I. 7.) AB on the unconstitutionality of certain provisions of Act on Election Procedure (Constitutional Court, 4 January 2013).

151 The Court enumerated following decisions in which it discussed foreign regulations and examined their usefulness in constitutionality review at hand: "Decision 13/2000 (V. 12.) AB on the symbols of the State, Decision 57/2001 (XII. 5.) AB on the right of reply, Decision 22/2003 (IV. 28.) AB on euthanasia, Decision 50/2003 (XI. 5.) AB on investigative committees, Decision $6 / 2007$ (II. 27.) $A B$ on the questions 8 related to the prohibition of the publication of opinion poll results, Decision 20/2007 (III. 29.) AB on the radio and TV broadcasting of the sessions of the Parliament, Decision 53/2009 (V. 6.) AB on domestic violence and restraining order", ibidem, para. III.3.4.

152 Ibidem, para. III.3.4. 
Rights. Some of the complaints were related to active suffrage, but most of them concerned exercising the passive right to vote. In assessing the complaints, the European Court of $\mathrm{Hu}$ man Rights [...] used a well-elaborated set of criteria, applied in almost all the election cases in the past years. ${ }^{153}$

In the ensuing passages the Court carefully determined the standards used by the ECtHR for the obligation of the State to guarantee the conditions for exercising the right to vote and registration of voters. ${ }^{154}$ The Court took these standards into account but underlined that its competence is limited by the scope of the petition.

\subsubsection{The Status of the Decisions of Foreign and International Courts}

The third example is the case decided in the same year as in the previous example, 2013, involving the constitutionality of the criminalization of the display of totalitarian symbols - 'five-point red star. ${ }^{155}$ The case is the example of the accommodation of the European standard in spite of the contrary ruling of the Constitutional Court. In the previous decision issued in 2000 the Constitutional Court held that the relevant provisions of the Criminal Code do not restrict the freedom of expression unnecessarily and disproportionately. ${ }^{156}$ In the meantime the ECtHR found in several cases that Hungary violated Art. 10 ECHR. ${ }^{157}$ The Constitutional Court agreed to accept the ECtHR decision against Hungary as 'a new circumstance' under Art. 31(1) of the Act on the Constitutional Court and ultimately found the contested provisions unconstitutional (on this case see in this volume contribution by Csatlós).

The Court observed that the judgments of the ECtHR have a declaratory character; they do not change the existing law. Viewed from this perspective, the findings of the ECtHR may help to clarify the content and the meaning of constitutional rights. The level of the constitutional protection should never fall below the standards provided by the ECHR, as interpreted in the case law of the ECtHR. Nevertheless, a national constitution may provide a higher level of protection than the ECHR. To establish this proper level the Constitutional Court referred to the laws of Slovakia, Germany, Italy, Lithuania, Latvia, Romania, Poland and Ukraine and shortly referred to the decisions of the constitutional courts of Germany, Italy and Poland. ${ }^{158}$

\footnotetext{
153 Ibidem, para. III.3.5.2.

154 Ibidem, III.3.5.3-3.5.4.

155 Case 4/2013 (II. 21.) AB (Constitutional Court).

156 Case 14/2000 (V. 12.) AB (Constitutional Court).

157 The leading case is Vajnai v Hungary, App. no. 33629/06 (ECtHR, 8 July 2008).

158 Cases of the German Federal Constitutional Court: 1 BvR 680/86 (3 April 1990); 1 BvR 204/03 (23 March 2006); 1 BvR 150/03 (1 June 2006); 2 BvR 2202/08 (18 May 2009); case 74/1958 (Italian Constitutional Court, 20 December 1958); case K 11/10 (Polish Constitutional Court, 19 July 2011). It is interesting to note that the Polish Constitutional Court in its judgment on
} 
The reasoning concerning the effect of the judgments of the ECtHR displayed by the Court is in concordance with its previous 2003 ruling on effects of the judgment of the ICJ. The case concerned the complaint of the Member of the Parliament against the Government on the legislative omission: failure to implement the 1992 Convention on Biological Diversity and the ICJ decision in the famous Gabčikovo-Nagymaros ${ }^{159}$ in which the ICJ found Hungary in breach of the treaty with Slovakia and obliged both States to negotiate. The Constitutional Court, referring to its constitutional powers, held that the judgment of the ICJ cannot be considered "a generally recognized principle of international law" or compared to the obligations stemming from the treaties that had become Hungarian law. Even though the jurisdiction of the International Court is based on the consent of the States parties to the treaty establishing the Court, its decision is neither a norm, nor a contract, but the resolution of a specific dispute, even if some of its statements are of significant general value. The International Court has no competence to annul domestic laws or to oblige the States to enact new laws even if this is the only way to fulfil the obligation. ${ }^{160}$ The Hungarian Court continued that also the Constitutional Court has no competence to force the Parliament or the Government to enact a law or conclude a treaty.

N. Chronowski and E. Csatlós observe that since the decisions of international courts are not recognised in Hungary as sources of international law they can be regarded only as reflecting interpretation of relevant treaties and as such can be taken into account by Hungarian courts. ${ }^{161}$ The authors invoke the decision of the Constitutional Court mentioned above (988/E/2000) and the decision of the Constitutional Court 18/2004 (V. 25.) AB in which the Court declared that the jurisprudence of the ECtHR "crafts and obliges the Hungarian practice" in a sense that Hungarian courts are bound by interpretation of the Convention, not a judgment as such. ${ }^{162}$ They also note that the Act on international treaties (Act L 2005) clearly states that the decisions of the international court rendered against Hungary are binding and shall be executed in Hungary. Such judgments have to be published in the Hungarian Official Journal (Magyar Közlöny). But it does not follow that the courts are bound by the judgment. In their opinion, the status of international courts decisions defined by the judgments of the Constitutional Court and the 2005 Act on international treaties determines the way

fascist, communist and totalitarian symbols discussed broadly the judgments of the Hungarian Constitutional Court, the German Constitutional Court and also the ECtHR Vajnai v Hungary case (para. 3).

159 Gabčikovo-Nagymaros Project, Hungary v Slovakia (ICJ, 25 September 1997).

160 Case 988/E/2000 (Constitutional Court, 7 October 2003) para. 3.3.

161 N. Chronowski, E. Csatlós (n. 115), p. 26.

162 Similarly, the Constitutional Court in case 61/2011 (VII. 13.) AB emphasised that the principle of pacta sunt servanda obliges the Constitutional Court to follow the ECtHR practice and its level of fundamental rights protection even if it is contrary to the previous practice of Hungary. 
the domestic courts refer to these decisions. They conclude, citing relevant judgments of Hungarian courts, that ordinary courts frequently cite international courts decisions (mainly the ECtHR), but they rarely really use them in their own argumentation. In many cases, the citation is only decorative or general without invoking expressis verbis the relevant judgment or indirect through the judgments of the Constitutional Court (common practice of the Municipal Court of Budapest). ${ }^{163}$ This technique seems to result from the specificity of Hungarian law, which does not allow the courts other than the Constitutional Court to adjudicate on constitutionality of a treaty or on a conflict between international and national law norms. Domestic courts have to refer in such cases to the Constitutional Court. ${ }^{164}$

\section{Lithuania}

\subsection{The Legal Setting for Judicial Dialogue}

Three other countries under our review: Lithuania, Russia and Ukraine share a common past of the former Soviet republics and the common legal culture. Post1991 they have started to function in a new environment and have undergone

163 N. Chronowski, E. Csatlós (n. 115), pp. 27-28.

164 The Act on the Constitutional Court of 2011 Section 32(2): "Judges shall suspend judicial proceedings and initiate Constitutional Court proceedings if, in the course of the adjudication of a concrete case, they are bound to apply a legal regulation that they perceive to be contrary to an international treaty." Under Section 42: "(1) If the Constitutional Court declares that such a legal regulation is contrary to an international treaty which, according to the Fundamental Law, shall not be in conflict with the legal regulation promulgating the international treaty, it shall - in whole or in part - annul the legal regulation that is contrary to the international treaty. (2) If the Constitutional Court declares that such a legal regulation is contrary to an international treaty which, according to the Fundamental Law, shall not be in conflict with the legal regulation promulgating the international treaty, it shall - in consideration of the circumstances and setting a time-limit - invite the Government or the law-maker to take the necessary measures to resolve the conflict within the time-limit set." This is the official translation of the Act (<http://www.mkab.hu/rules/act-on-the-cc>, access: 25 September 2016), the Hungarian text more clearly shows that the two situations are distinct. Paragraph 1 refers to a conflict between a treaty promulgated by the act of the Parliament and the act of government while para. 2 - to the conflict between a treaty promulgated by governmental decree and the act of government. The Act of 2011 does not answer the question of the same rank sources collisions, i.e. if a treaty is promulgated by the act of Parliament, and the domestic legal act conflicting with it is also the act of Parliament. N. Chronowski, E. Csatlós, Hoffmann T., 'Country Report Hungary' para. IV.1; N. Chronowski, E. Csatlós (n. 115) 25, n. 107. 
the process of adaptation. Lithuania has experienced the deepest and the fastest changes striving hard to become the member of the Council of Europe and, later, the member of the EU.

The first constitutional Act "On re-establishment of independence" adopted on 11 March 1990 declared Lithuania's commitment to democracy, human rights and the rule of law by stating that "Lithuania stresses its adherence to universally recognised principles of international law." In the 1992 Constitution Art. 135 repeated: "in implementing its foreign policy, the Republic of Lithuania shall follow the universally recognized principles and norms of international law." According to Art. 138 of the Constitution, "international treaties which are ratified by the Seimas of the Republic of Lithuania shall be the constituent part of the legal system of the Republic of Lithuania." In 1999 Lithuania adopted the Law "On international treaties". The Law explains that ratified international treaties and agreements may be directly applicable and in a case of conflict prevail over national law. ${ }^{165}$ The Constitutional Court confirmed the primacy of ratified international treaties, stressing, nevertheless, "the legal system of the Republic of Lithuania is based on the fact that no law or other legal act as well as international treaties (in this case the European Convention on Human Rights) may contradict the Constitution." 166 The 2004 Constitutional Act "On membership in the EU" (which is a part of the Constitution) declared the primacy of EU primary law and secondary law over domestic legislation maintaining the superior position of the Constitution in the determined hierarchy. ${ }^{167}$ In 2006

165 A treaty is ratified by parliament in a form of ratification act (statute) and published later in the official gazette (Valstybès žinios). There are delays lasting in some cases for several years. The international treaties and agreements, which were not ratified, but approved by the Government - have a status lower than statutes and higher than governmental decrees and should also be applied directly by the courts. Cf. V. Vaičaitis, 'Country Report Lithuania' para. 1.

166 Case 22/94 (Constitutional Court, 24 January 1995) on the Convention for the Protection of Human Rights and Fundamental Freedoms. The Court added: "This general requirement is directly connected with the relation between the international law and domestic (national) laws of the states in general and with respect to separate problems, specifically to the problem of human rights and freedoms. Nowadays, the system of the so-called parallel adjustment of international and domestic law is perhaps the most widely spread in Europe; it is based on the rule that international treaties are transformed in the legal system of a state (i.e. are incorporated in it). Such a way of the realisation of international treaties, the Convention among them, is established in the Constitution of the Republic of Lithuania." Cf. 8/95 (Constitutional Court, 17 October 1995).

167 In case 17/02-24/02-06/03-22/04 (Constitutional Court, 14 March 2006) on the limitation on the rights of ownership in areas of particular value and in forest land the Court recalled its previous case law confirming that the treaties ratified by the Seimas "acquire a force of a law". "This doctrinal provision cannot be construed as meaning that, purportedly, the Republic of Lithuania may disregard its international treaties, if a different legal regulation is established in its laws or constitutional laws than that established by international treaties. Quite to the contrary, the principle entrenched in the Constitution that the Republic of Lithuania observes international obligations undertaken of its own free will and respects universally 
the Constitutional Court summed up that "the observance of international obligations undertaken on its own free will, respect to the universally recognized principles of international law (as well as the principle pacta sunt servanda) are a legal tradition and a constitutional principle of the restored independent State of Lithuania." 168

The references to international law are not only in the Constitution but they could be found likewise in some statutes, e.g. Art. 33 of the Law on Courts ${ }^{169}$ under the heading "Sources of law for adjudicating cases", stipulates that the courts are to follow the Constitution, national laws, "international treaties of the Republic of Lithuania", acts of the Government and other acts, under the condition that they do not contradict with the laws. Article 4(1) of the Administrative Proceedings $\mathrm{Act}^{170}$ lays down a general rule that the court must not apply any law, which contradicts the Constitution. Article 4(3) of the Law on Administrative Proceedings states that the administrative courts are bound by the judgments and preliminary rulings of the CJEU and obliges them in cases provided for by law to refer to the CJEU for a preliminary ruling on questions of application and validity of EU law. The same Law in Art. 6(6) in cases of lack of relevant legislation authorises the courts to rely on general principles of law (including international law principles) and the principles of fairness and reasonableness. ${ }^{171}$ The similar technique of specific authorisations for the courts to apply international law, which function aside the Constitution, is practiced in other States as well. However, in Lithuania, Russia and Ukraine the technique is used probably more frequently than in Poland or in the Czech Republic. The reason could be that their courts before 1990s have not applied international law at all and they were used to follow binding guidelines of the higher courts.

After the experience of the Soviet totalitarian regime, Lithuania had to change not only its political or judiciary system, but the judges had also to adjust their legal thinking. The Constitutional Court of Lithuania established in 1993 played

recognised principles of international law implies that in cases when national legal acts (inter alia, laws or constitutional laws) establish a legal regulation which competes with that established in an international treaty, then the international treaty should be applied" (para. III.9.2). The Court further added: "Thus, the Constitution consolidates not only the principle that in cases when national legal acts establish the legal regulation which competes with that established in an international treaty, then the international treaty should be applied, but also, in regard of European Union law, establishes expressis verbis the collision rule, which consolidates the priority of application of European Union legal acts in the cases where the provisions of the European Union arising out of the founding Treaties of the European Union compete with the legal regulation established in Lithuanian national legal acts (regardless of what their legal force is), save the Constitution itself" (para. III.9.4).

168 Ibidem, para. III.9.1.

169 The Law on Courts (Lietuvos Respublikos teismų įstatymas), Official Gazette, 1994, no. 46-851; 2002, no. 17-649.

170 The Law on Administrative Proceedings (Lietuvos Respublikos administracinių bylų teisenos istatymas), Official Gazette, 1999, no. 13-308; 2000, no. 85-2566.

171 V. Vaičaitis, 'Country Report Lithuania' para. 2. 
in that process a vital role. It adapted many concepts from other jurisdictions, especially from the ECtHR and the CJEU case law, e.g. to substantiate the principle of the rule of law (teisines valstybes principas), enshrined in the Preamble to the Constitution, the principle of certainty of law, proportionality or the protection of legitimate expectations. In the majority of cases, this was done without invoking any foreign or international decisions (silent dialogue).

For example in the 2002 judgment on state social insurance pensions the Constitutional Court found the provisions of Lithuanian law reducing the amount of elderly pensions after so called 1999-2000 "Russian economic crises" to be contrary to the rule of law which encompasses, according the Court, the respect of human rights and the protection of legitimate expectations. ${ }^{172}$ The Court made the reference as well to Art. 9 of the International Covenant on Economic, Social, and Cultural Rights as the basis for the right to social security including social insurance. ${ }^{173}$

In the 2010 judgment "on the right of the persons, who sustained damage due to genocide, to demand that the natural persons who committed this crime compensate such damage" the Court observed that "[d]uring the occupations of Lithuania carried out both by the USSR and by the Nazi Germany, not only democracy was denied, but also crimes against the residents of an occupied State were committed, inter alia genocide was perpetrated. It is obvious that, during the years of the occupation, the persons who had suffered from crimes of genocide perpetrated by the natural persons who were serving the occupation regimes were unable to implement their right to demand that the natural persons who had perpetrated the crimes of genocide compensate the damage." ${ }^{174}$ The Court determined the claimed right referring for support of its argumentation to international law instruments and the concept of the rule of law..$^{175}$

The Constitutional Court made also important contribution in clarifying the way the international treaties have to be applied. It distinguished various kinds of treaties and their different legal effects relying strongly on the VCLT. In the ruling "On the Law 'On International Treaties of the Republic of Lithuania"' the Constitutional Court, even the priority over the Constitution, explained referring to the Convention:

The legal system of the Republic of Lithuania is grounded on the fact that any law or other legal act, as well as international treaties of the Republic of Lithuania, must not contradict the Constitution, because Paragraph 1 of Article 7 of the Constitution prescribes: "Any law or other statute which contradicts the Constitution shall be invalid." This constitutional provision of itself cannot invalidate a law or an international treaty but it requires that

172 Case 41/2000 (Constitutional Court, 25 November 2002) para. II.2.1.

173 Ibidem, para. II.1.4. See also e.g. for the concept of democracy case 19/94 (Constitutional Court, 20 April 1995).

174 Case 09/2008 (Constitutional Court, 29 November 2010) para. III.7.

175 Ibidem, para. III.5. 
the provisions thereof would not contradict the provisions of the Constitution. Otherwise the Republic of Lithuania would not be able to ensure legal defence of the rights of the parties of international treaties, which arise from those treaties, and this in its turn would hinder from fulfilling obligations according to the concluded international treaties. This would contradict the 1969 Vienna Convention on the Law of International Treaty, which was undertaken to respect and execute by the Republic of Lithuania according to the 29 January 1991 Declaration of the Supreme Council "On the Obligations of the Republic of Lithuania Arising out of International Treaties in the Spheres of Diplomatic and Consular Relations." At the same time the most important principles of said Convention would be also violated, namely: pacta sunt servanda, i.e., "every treaty is binding to be performed" (Article 26 of the Convention) and "a party may not invoke the provisions of its internal law as justification for its failure to perform a treaty" (Article 27 of the Convention). It is important therefore that consecutive order of concluding, implementing and terminating international treaties would be established and that it would be in conformity with the provisions of the Constitution concerning international treaties as well as principles and norms of this sphere of international law. ${ }^{176}$

In the same ruling the Constitutional Court made a distinction between the ratified and the not ratified treaties. According to the Court, only the ratified treaties have the status of a parliamentary statute and they have to comply with the Constitution, while the non-ratified treaties have to comply with laws and the Constitution. ${ }^{177}$ The Court defined also the notion of a treaty (relying on the VCLT) to distinguish treaties and other agreements of ministries or institutions of the Government, which are not governed by international law. ${ }^{178}$

\subsection{Deference to International and Foreign Courts Decisions}

There are many judgments of all kinds of courts, the ordinary courts, the administrative courts or the Constitutional Court applying international treaties directly or for the purpose of interpretation of domestic law. ${ }^{179}$ But the references to the decisions of the courts of other jurisdictions are not frequent and in majority of cases they concern case law of the ECtHR ${ }^{180}$ and the CJEU.

176 Case 8/95 (Constitutional Court, 17 October 1995), English translation <http://www.lrkt.lt/ en/court-acts/search/170/ta983/content> (access: 25 September 2016).

177 Ibidem, para. II.3.

178 Ibidem, para. II.4.

179 See e.g. cases reproduced in Republic of Lithuania Materials on International Law contained in Baltic Yearbook of International Law volumes 6/2006, 449-478; 7/2007, 453-473; 8/2008, 347-384; 9/2009, 295-349; 10/2010, 457-506; 11/2011, 517-598; 12/2012, 377-462.

180 See e.g. case $1 / 2013$ (Constitutional Court, 26 February 2013) on the prohibition on correspondence between convicts. 


\subsubsection{The Judges Salaries Case}

In the judgment of 2001 concerning the reduction of the salaries of judges the Constitutional Court made an inquiry into international documents on the independence of judiciary (i.a. UN GA resolution of 13 December 1985 which adopted the Basic Principles on the Independence of the Judiciary, the Council of Europe Recommendation on the Independence, Efficiency and Role of Judges of 13 October 1994, the European Charter on the Statute for Judges of 10 July $1998)^{181}$ and the decisions of the constitutional courts of democratic States dealing with the salaries of the judges as an element of their independence. The Court observed:

It needs to be noted that the principle that the salary of the judge during his continuance in office may not be diminished was entrenched as far back as in the 1787 USA Constitution (Section 1 of Article III). Later on it was taken over by constitutional law of other democratic countries. In some countries it is directly stated in the texts of basic laws, while in others it is considered an integral element of the principle of independence of judges and courts established in the Constitution. In the constitutional doctrine various aspects of the element of the principle of independence of judges and courts have been disclosed. For instance, in its decision of 15 September 1999, the Constitutional Court of the Czech Republic emphasised the inalienable right of the judge to undiminished salary and the prohibition against the categorisation of judges as public servants. In its decision of $17 \mathrm{Sep}$ tember 1997, the Supreme Court of Canada noted that it is impermissible to diminish salaries of judges in an attempt to evade the budget deficit. In the decision of 4 October 2000 of the Constitutional Tribunal in Poland it is held that the salaries of judges must be especially protected against unfavourable fluctuations in case of difficulties in the area of state budget, etc. ${ }^{182}$

The ruling is certainly one of the examples of the concurring dialogue. ${ }^{183}$

\subsubsection{The Concept of Family in State Policy Case}

In the 2011 judgment on the State family policy concept the Constitutional Court dealt with a sensitive issue of the modern notion of family. To construct the constitutional conception of family the Constitutional Court relied inter alia on international law commitments of Lithuania, especially on the ECHR. The Court analysed Marckx v Belgium, Kroon and others $v$ The Netherlands,

181 Case 13/2000-14/2000-20/2000-21/2000-22/2000-25/2000-31/2000-35/2000-39/2000-8/01$31 / 01$ (Constitutional Court, 12 July 2001) on the reduction of judges' salaries, para. III.4.3.

182 Ibidem, para. III.4.5.

183 The Constitutional Court like e.g. the Hungarian Court (cf. n. 139) referred to foreign decisions providing only dates, in this case the dates are correct. The Court referred to case Provincial Judges Reference (Supreme Court of Canada, 17 September 1997) 3 S.C.R.; case P/8/0 (Polish Constitutional Court, 4 October 2000). 
Keegan v Ireland, El Boujaïdi v France ${ }^{184}$ to conclude that "the concept of family analysed in the jurisprudence of the ECHR is not confined to the notion of the traditional family founded on the basis of marriage. The ECHR has held more than once that other types of the relationship of living together are also protected under Art. 8 of the Convention, as those, which are characterised by a permanence of the relationship between persons, the character of assumed obligations, common children, etc. It also needs to be noted that the ECHR jurisprudence does not provide any comprehensive list of the criteria defining the family." ${ }^{185}$ Moreover, the judgment contains a thorough inquiry into the decisions of the constitutional courts of the Czech Republic, Slovenia, Croatia, Hungary, France, and of Germany. The Constitutional Court observed that the practice of constitutional courts is not uniform, "the family is defined by taking into consideration the plurality of forms of family life prevailing in society at a particular period of time, as well as the demographic, economic and social changes in the life of society." ${ }^{186}$ On these basis the Constitutional Court determined the constitutional standard. It found that the concept of family under Lithuanian Constitution may not be reduced to "such notions of family under which only a man and a woman who are married or were married, as well as their children (adopted children), are regarded as a family" but it has to extend to "other family relations, inter alia those of the life of a man and a woman, who are not and were not married, as well as their children (adopted children) living together, that are based on the permanent bonds of emotional affection, reciprocal understanding, responsibility, respect, shared upbringing of the children and similar ones, as well as on the voluntary determination to take on certain rights and responsibilities, which are characteristic of the family as a constitutional institute." 187

184 Marckx v Belgium, App. no. 6833/74 (ECtHR, 13 June 1979), Kroon and others $v$ The Netherlands, App. no. 18535/91 (ECtHR, 27 October 1994), Keegan v Ireland, App. no. 16969/90 (ECtHR, 26 May 1994), El Boujaïdi v France, App. no. 25613//94 (ECtHR, 26 September 1997).

185 Case 21/2008 (Constitutional Court, 28 September 2011), English translation <http://www. Irkt.lt/data/public/uploads/2015/04/2011-09-28_n_ruling.pdf> (access: 25 September 2016), para. III.2.

186 Ibidem, para. III.3.

187 Ibidem, para. IV.14. In respect of the notion of family it is interesting to compare case re Kostroma Region Law 987-АПГ 12-2 (Supreme Court, 7 November 2012) in which the Russian Court referred only to Art. 16(3) of the Universal Declaration of Human Rights and treaties that require to protect the family as the fundamental group of society and the natural environment for the growth and well-being of all its members and particularly children (e.g., Art. 10(1) of the International Covenant on Economic, Social and Cultural Rights, preamble to the UN Convention on the Rights of the Child of 1989). It did not invoke any decisions of foreign or international courts noticing that pursuant to federal law, in accordance with the national traditions and subject to international law, the family values do not include homosexual relations, bisexuality and transgender. Therefore, by adopting the law in question the Kostroma region did not impose unreasonable restrictions on rights but acted within the scope of its competence as the disputed law prohibits the propaganda of homosexuality, bisexuality, 
The decision of the Constitutional Court is largely grounded in domestic law. The references to international instruments or foreign jurisdictions have subsidiary character with the sole purpose, as it seems, to strengthen and support the findings of the Court.

\subsubsection{The Paksas Case - the Status of the Decisions of Foreign and International Courts and the Dissenting Dialogue}

In Lithuanian practice it is also possible to find the judgment opposing the ruling of the international court. The Paksas case is well known and studied elsewhere in this volume (see Skomerska-Muchowska). Therefore, in this introductory section we confine ourselves to a brief account.

In 2012 the Constitutional Court had an occasion to react to the 2011 ECtHR Paksas $v$ Lithuania ${ }^{188}$ judgment which evaluated Lithuanian law differently than it had been previously done by the Constitutional Court. ${ }^{189}$ In 2004 the Constitutional Court held as constitutional the provisions of Lithuanian law prohibiting a person who had been removed from the office of the President for a gross violation of the Constitution or a breach of the oath to be again elected the President of the Republic or a member of the Seimas or hold an office for which it was necessary to take an oath. ${ }^{190}$

Dealing with President Paksas, who had been removed from the office as a result of the impeachment proceedings, the ECtHR, taking account of the permanent and irreversible prohibition for the applicant to stand in elections to the parliament, recognised that this restriction was disproportionate and that Art. 3 of Protocol No. 1 of the Convention was violated.

transgender as relations negating the family values and imposes administrative liability for the propaganda thereof within the constituent entity of the Russian Federation, which is in compliance with the applicable federal laws.

188 Paksas v Lithuania, App. no. 34932/04 (ECtHR, 6 January 2011).

189 Paksas 8/2012 (Constitutional Court, 5 September 2012) on the prohibition for a person, who was removed from office under procedure for impeachment proceedings, to stand in elections for a Member of the Seimas, <http://www.lrkt.lt/en/court-acts/search/170/ta1055/content> (access: 24 September 2016).

190 Case 24/04 (Constitutional Court, 25 May 2004) para. III.6: "The Constitution does not provide that, after a certain time has elapsed, a president whose actions have been recognised by the Constitutional Court as having grossly violated the Constitution, and who has been found to have breached the oath and has been removed from office by the Seimas [on that account] [...] may [subsequently] be treated as though he had not breached the oath or committed a gross violation of the Constitution [...]. [A person] [...] who has been removed from office by the Seimas, the body representing the people, will always remain someone who has breached his oath to the nation and grossly violated the Constitution, and who has been dismissed as President for those reasons [...]. [A person removed from the office of President] may never again [...] give an oath to the nation, as there would always exist a reasonable doubt [...] as to its reliability [...]." English translation: The Constitutional Court of the Republic of Lithuania on the Law on Presidential Elections, <http://www.Irkt.lt/en/court-acts/ search/170/ta1269/content> (access: 24 September 2016). 
In 2012 the Constitutional Court reviewed the constitutionality of the amendments to Lithuanian law implementing the ECtHR judgment. The Constitutional Court confirmed the doctrine in regard to the impeachment procedure and the consequences of the breach of oath. The Court insisted that it cannot change the doctrine firmly grounded in the Constitution on the basis of the ECtHR judgment. ${ }^{191}$ The doctrine could be changed only with an amendment of the Constitution. ${ }^{192}$ The Constitutional Court did not question the arguments of the ECtHR but discussed rather the potential legal consequences of the ECtHR judgment. The Court pointed first to the different roles of both Courts. The Constitutional Court is the guardian of the Constitution while the ECtHR is responsible for the effective implementation of the ECHR. However, the role of the ECtHR is subsidiary to that of a State party to the ECHR, which is primarily obliged to apply the Convention. The obligation is the one of result, so a State may choose the way of the implementation of the Convention or the judgment of the ECtHR taking into account its national law, and especially the Constitution. In a situation at hand, the Constitutional Court is obliged to respect the Constitution; therefore, the incompatibility between the Lithuanian law and the ECHR may be removed only by the adoption of the corresponding amendment(s) to the Constitution. ${ }^{193}$ Despite several efforts, the Constitution has not yet been amended. ${ }^{194}$

Paksas is certainly a political case and so a unique one as Judge Costa rightly emphasised in a partly dissenting opinion annexed to the ECtHR decision. Judge Costa found the ECtHR judgment 'moderate and balanced' and shared the conviction of the majority that the lifelong disqualification from standing for election

191 Paksas 8/2012 (Constitutional Court, 5 September 2012) para. III.5: "Consequently, in itself the judgment of the European Court of Human Rights may not serve as the constitutional basis for reinterpretation (correction) of the official constitutional doctrine (provisions thereof) if such reinterpretation, in the absence of corresponding amendments to the Constitution, changed the overall constitutional regulation (inter alia the integrity of the constitutional institutes - impeachment, the oath and electoral right) in essence, also if it disturbed the system of the values entrenched in the Constitution and diminished the guarantees of protection of the superiority of the Constitution in the legal system." English translation available at <http://www.lrkt.lt/en/court-acts/search/170/ta1055/content> (access: 24 September 2016).

192 Ibidem, para. III.6: "In the context of the constitutional justice case at issue it needs to be noted that from Para. 1 of Art. 135 of the Constitution a duty arises for the Republic of Lithuania to remove the aforesaid incompatibility of the provisions of Art. 3 of Protocol No. 1 of the Convention with the Constitution, inter alia the provisions of Para. 2 of Art. 59 and Article 74 thereof. While taking account of the fact that, as mentioned, the legal system of Lithuania is grounded upon the principle of superiority of the Constitution, the adoption of the corresponding amendment(s) to the Constitution is the only way to remove this incompatibility."

193 Ibidem, para. III.2.

194 See the Council of Europe information on the monitoring of the execution of judgments $<$ http://www.coe.int/t/dghl/monitoring/execution/Reports/pendingCases_en.asp?CaseTitleOrNumber=\&StateCode=LIT\&SectionCode= $/>$ (access: 23 June 2016). 
is excessive and unacceptable. However, he emphasised that the impeachment proceedings are rarely instituted not only in Europe but elsewhere in the world and are hardly ever carried through to completion. The allegations against President Paksas were not trivial and he was removed from the office by the Parliament who followed the ruling of the Constitutional Court. "In such a specific and delicate field as electoral law, and in a case involving the complex relations between the different public authorities, subject to the ultimate scrutiny of the electorate, and thus the sovereign people" Judge Costa advocated restraint noting that the State has a wide discretion, and therefore "the legitimate European supervision in this case should be restricted or limited." 195

\section{The Russian Federation}

\subsection{The Legal Setting for Judicial Dialogue}

Prior to the adoption of the Russian Constitution in 1993 both in Russian theory and in practice the issue of the relationship between international and national legal systems had been neglected. ${ }^{196}$ International law was not taken into account by national law or it was treated similarly to national law without considering its peculiarity. ${ }^{197}$ The idea of priority of national law dominated. It was understood that " $[t]$ he national legal system is as sovereign as the State because on the territory of the country without the sanction (in one form or another) of national State power norms cannot operate created besides by the law-creation agencies thereof." ${ }^{198}$ Against this background, Art. 15(4) of the 1993 Russian

195 Paksas v Lithuania, App. no. 34932/04 (ECtHR, 6 January 2011), the partly dissenting opinion of Judge Costa joined by Judges Tsotsoria and Baka, para. 12.

196 Cf. L. Mälksoo, Theory of International Law in Contemporary Russia (Oxford University Press 2015), p. 111. On the specific attitude and its reasons of the Russian scholarship towards foreign and international courts practice see: L. Mälksoo, Russian Approaches to International Law (Oxford University Press 2015), p. 77. For a general overview see R. Tkatova, 'Russian spirit, soviet heritage and Western Temptation: "UN-'Peaceful Coexistence" in Russia's International Doctrine and Practice' (2012), p. 12, Baltic Yearbook of International Law, pp. 1-28; S.Yu. Marochkin, 'Contemporary Approaches of the Russian Doctrine to International Law: Identical to Western Ones?' (2012) 12 Baltic Yearbook of International Law, pp. 29-56. L. Mälksoo, 'International Law in Russian Textbooks: What's in the Doctrinal Pluralism?' (2009) 1 Goettingen Journal of International Law, pp. 279-290.

197 N. Babai, V.S. Timoshenko, 'General Principles and Norm of International Law in the Russian Legal System' (2007) 1 Russian Law: Theory and Practice, p. 78, see also, pp. 77-82.

198 A.M. Vasilev, 'On the Systems of Soviet and International Law' (1985) 1 Sovietskoje gosudarstwo i prawo, p. 69, cited by N. Babai, V.S. Timoshenko, 'General Principles and Norm of International Law in the Russian Legal System' (2007) 1 Russian Law: Theory and Practice, p. 77. 
Constitution declaring priority of international law marks an important change. ${ }^{199}$ The opening of the Constitution to international law was brought about not without a strong conceptual debate in Russian scholarship and opposition from scholars, politicians and judges. ${ }^{200}$ The majority view is that the provision provides the grounds for the application of international law in domestic sphere. It binds equally in law-creation as in law-application. Since the provision is located in the first Chapter of the Constitution, which is under more stringent conditions for amendment than the other provisions of the Constitution, it is perceived as one of the fundamental principles of the Russian constitutional legal order. ${ }^{201}$ The provision reads:

199 The Constitution of 1977 contained Art. 29 which i.a. expressed the intention to honour obligations stemming from generally recognized principles and norms of international law in good faith. The provision was understood only as enumerating the principles that the USSR intended to follow in its foreign policy. Cf. L. Mälksoo, Theory of International Law in Contemporary Russia (Oxford University Press 2015), p. 112. On general overview of constitutional bases for application of international law see W.E. Butler, 'Russian Federation', [in:] D. Sloss (ed.), The Role of Domestic Courts in Treaty Enforcement, A Comparative Study (Cambridge University Press 2014), pp. 410-447; S.Yu. Marochkin, 'International Law in the Courts of the Russian Federation: Practice of Application' (2007) 6(2) Chinese Journal of International Law, pp. 239-344.

200 L. See Mälksoo, Theory of International Law in Contemporary Russia (Oxford University Press 2015), p. 111. The relationship between international and Russia's domestic law is one of the main topics of debates in the post-Soviet Russian theory of international law closely linked to the question whether individuals can be subjects of international law. The author concludes that Russian theory of international law on such issues tends to have different accents and positions than what have become mainstream in the postWorld War II 'liberal' west.

201 Cf. A. Abashidze, 'The Relationship Between International Law and Municipal Law: Significance of Monism and Dualism Concepts' Basic Concepts of Public International Law, Monism \& Dualism, Faculty of Law of Belgrade University (May 2013), p. 25. The author classifies the Russian system as monistic. However, the approach taken by the Constitutional Court in Markin case (n. 228) is rather dualistic. See case 27-П/2013 (Constitutional Court, 6 December 2013). Cf. O.V. Belianskaia, O.A Pugina., 'Implementation of International Legal Norms in Russian Legislation' (2006) 1 Russian Law: Theory and Practice, pp. 82-89. For Russian scholarly discussion on the issue see L. Mälksoo, Theory of International Law in Contemporary Russia (Oxford University Press 2015), p. 112. The author observes i.a.: "Russia's constitution may be monist but conservative scholars continue to interpret the position of international law in Russia in a dualist fashion. Moreover, the more the Russian government has run into conflicts with norms of international law, the more audible has become the voice in the country's politics that demands amendment of the constitutional provision stipulating the priority of international law over domestic law. As the deputy Yevgeny Alekseevich Fedorov (b. 1963) from the governing 'United Russia' fraction argues populistically, currently the priority of 'international law' actually means the priority of 'American law'.' Ibidem, p. 122. For general overview see Y. Tikhomirov, 'Russia', [in:] D.L. Shelton (ed.), International Law and Domestic Legal Systems: Incorporation, Transformation, and Persuasion (Oxford University Press 2011), pp. 517-525. 
Universally recognized principles and norms of international law as well as international agreements of the Russian Federation should be an integral part of its legal system. If an international agreement of the Russian Federation establishes rules, which differ from those stipulated by law, then the rules of the international agreement shall be applied. ${ }^{202}$

This principle is elaborated in the Federal Law "On International Treaties of the Russian Federation" of 1995 which concerns the conclusion, implementation and termination of international treaties in Russia. It was repeated almost in all codes and Federal Laws. ${ }^{203}$

Additionally, the Constitution recognizes the special status of human rights norms stating in Art. 17(1) that: "In the Russian Federation recognition and guarantees shall be provided for the rights and freedoms of man and citizen according to the universally recognized principles and norms of international law and according to the present Constitution." Moreover, the Russian courts recognized the obligation to apply the ECtHR case law (legal positions of the ECtHR) ${ }^{204}$

202 Translation available at http://archive.kremlin.ru/eng/articles/ConstEng1.shtml (access: 20 June 2016). There is no single official translation of the Constitution of the Russian Federation in English.

203 E.g E. Ivanow, A. Belyachenkova, 'Country Report Russian Federation' para. 1.2: "Pursuant to Article 3 of the Federal Constitutional Law No. 1-FKZ 'On the Judicial System of the Russian Federation' dated 31 December 1996, the integrity of the judicial system of the Russian Federation is ensured through the application by all courts of the generally recognised principles and rules of international law and the international treaties of the Russian Federation. As set out in Article 11.4 of the Russian Code of Civil Procedure, where an international treaty of the Russian Federation provides for the rules other than those provided for by law, the court in considering a civil case shall apply the rules of the international treaty. A similar provision is contained in the Civil Code. In criminal law, the rules of international treaties that require states to consider certain acts as criminal ones shall not be applied directly. In Russia, the crimes and the punishment for criminal acts are determined solely by the Criminal Code of the Russian Federation (Russian Criminal Code). New components of crime shall be included in the Russian Criminal Code based on the international treaties. Certain articles of the Russian Criminal Code contain references to the international treaties. For instance, Article 356 of the Russian Criminal Code establishes criminal liability for using the prohibited means and methods of warfare. The concept of the 'prohibited means and methods of warfare' is defined in the Geneva Conventions. Pursuant to Article 1.3 of the Russian Code of Criminal Procedure 'the generally recognised principles and rules of international law and the international treaties of the Russian Federation shall form an integral part of the criminal procedure laws and regulations of the Russian Federation. If an international treaty of the Russian Federation sets out the rules other than those provided for by this Code, the rules of the international treaty shall apply'. Finally, as set out in Article 1.1(2) of the Russian Code of Administrative Offences, the Code is based on the generally recognised principles and rules of international law, and sets out the prevailing nature of the rules of international treaties over the provisions of law on administrative offences."

204 See the Ruling of the Plenary Session of the Supreme Court of the Russian Federation no. 5 (10 October 2003) "On Application of the Universally Recognized Principles and Norms of International Law and International Treaties of the Russian Federation by the Courts of General 
From the other provisions of the Constitution it is possible to infer that treaties do not prevail over the Constitution (Art. 15(1) ${ }^{205}$ and Art. 125(6) $\left.{ }^{206}\right)$. Some further restrictions concerning the application of the different kinds of treaties were elaborated in statutes and by the practice. ${ }^{207}$

It is important to note that the Russian Constitutional Court as early as in 1995 based the priority of international norms on the principle of the rule of law. The Court held that "In accordance with the principles of the rule of law State consolidated in the Constitution of the Russian Federation, the agencies of power are bound in their activity by both municipal and international law. Generally-recognized principles and norms of international law and international treaties should be complied with in good faith, including by means of taking them into account by municipal legislation." ${ }^{208}$ In 1997 the same Court

Jurisdiction", paras 10-15, the Ruling of the Plenary Session of the Supreme Court of the Russian Federation no. 23 (19 December 2003) para. 4, the Ruling of the Plenary Session of the Supreme Court of the Russian Federation no. 3 (24 February 2005) "On Judicial Practice in Cases of Protection of Honour and Dignity and Business Reputation of Citizens and Legal Entities", the Preamble and paras 1 and 9. Cf. Vorontsova I.V., 'Problems of International Law Interpretation (on the example of the Convention on the Protection of Human Rights and Fundamental Freedoms) in the lights of the ECHR judgment in the case of K. Markin' (2015) 1 Russian Law: Theory and Practice 100. On the attitude of judges and of litigators towards the ECHR see A. Burkov, 'Motivation for Direct Application of the Convention for the Protection of Human Rights and Fundamental Freedoms in Russian Courts' (2012) 12 Baltic Yearbook of International Law, pp. 229-247.

205 Article 15(1) of the Constitution provides for the primacy of the Constitution, it reads: "The Constitution of the Russian Federation shall have supreme legal force, direct effect and shall be applicable on the entire territory of the Russian Federation. Laws and other legal acts, which are adopted in the Russian Federation, must not contradict the Constitution of the Russian Federation."

206 Art. 125(6) of the Constitution stipulates: "Acts or certain provisions thereof, which are recognized as unconstitutional, shall lose force; international treaties of the Russian Federation, which do not correspond to the Constitution of the Russian Federation, shall not be implemented or used."

207 The Supreme Court stated in the Ruling of the Plenary Session of the Supreme Court of the Russian Federation no. 8 (31 October 1995) para. 5: "The court shall not apply the governing law in determining the case where an international treaty of the Russian Federation which has consented to be bound by the treaty by adopting the federal law and for which the treaty is in force sets out the rules other than those provided for by law. In these cases, the rules of the international treaty of the Russian Federation shall apply." Paragraph 8 of the Ruling of the Plenary Session of the Supreme Court of the Russian Federation no. 5 (10 October 2003) explains the hierarchy. It states that the treaty ratified upon the consent in the form of a federal law, has priority of application over the laws of the Russian Federation. The treaty for which the consent was given in a form other than a federal law, shall prevail over the subordinate legislation and regulations issued by the State authority concluding a treaty.

208 Decree of the Constitutional Court (31 July 1995) cited by A.N. Babai, V.S. Timoshenko, 'General Principles and Norm of International Law in the Russian Legal System' (2007) 1 Russian Law: Theory and Practice 78. In the same token see e.g. O.A. Ishchenko, E.G. Ishchenko, 
ruled that the Constitutional Court of the Russian Federation "is not entitled to either fill the gaps in the legal regulation or solve the problem of whether the international legal act can be applied to a specific case if any inconsistency is found in the domestic law - it is the responsibility of courts of general jurisdiction." ${ }^{209}$

In Article 7 of the Russian Civil Code it is noted that international treaties apply directly. ${ }^{210}$ The meaning of this term is developed in the Federal Law on International Treaties by reference to the concept of self-executing and non-self-executing treaties. A self-executing treaty does not require any clarification or implementation in internal law and it is thus directly applicable. Article 5 of the Federal Law on International Treaties specifies that only provisions of officially published treaties may be applied directly. ${ }^{211}$ Article 3 of the Criminal Code of the Russian Federation excludes direct applicability of international treaties in certain aspects of criminal law. This does not mean that the international treaties are not applied in other spheres of criminal law and criminal proceedings. The provision reads: "The criminality of an act, and also the punishability thereof and other criminal consequences, shall be determined only by the present Code."

To ease the application of international law by general courts, in concordance with the Russian tradition, the plenary of the Supreme Court enacted the detailed Ruling no. 5 of 10 October 2003 (amended in 2013) on application of international law. ${ }^{212}$ The Ruling is addressed to the ordinary courts and its main objective is to ensure the correct and uniform application of international law by the courts. The resolution of the Supreme Court interprets relevant legislation and is binding for lower courts. It is a general interpretative ruling with obvious significance for the development of the courts practice. ${ }^{213}$

'Implementation of International Law in Russian Legislation' (2008) 2 Russian Law: Theory and Practice 196.

209 Case 87-O (Constitutional Court, 3 July 1997) "On Refusal to Accept the Request of the Moscow Regional Court, Judge N.V. Grigorieva for Consideration." Cited by Vorontsova I.V. (n. 205).

210 O.A. Ishchenko and E.G. Ishchenko ('Implementation of International Law in Russian Legislation' (2008) 2 Russian Law: Theory and Practice 197) argue that the term 'directly applicable' does not mean direct operation of international law, but incorporation of international treaties into the Russian legal system.

211 Ibidem, 197.

212 The Ruling of the Plenary Session of the Supreme Court of the Russian Federation no. 5 "On the Application of Universally Recognized Principles and Norms of International Law and of International Treaties of the Russian Federation by Courts of General Jurisdiction" (10 October 2003) amended by the Ruling of the Plenary Session of the Supreme Court of the Russian Federation no. 4 (5 March 2013), available at <http://www.supcourt.ru/catalog.php?c1=English\&c2=Documents\&c3=\&id=6801> (access: 26 September 2016).

213 It was referred to and followed in other resolutions of the Supreme Court on implementation of international law in specific fields, e.g. in cases concerning maritime law, labour law, honour and dignity of citizens, drug substances, adoption. The Supreme Arbitrazh Court 
The Ruling no. 5 refers to Art. 15(4) of the Constitution and Federal Law No. 101-FZ of 15 July 1995 "On International Treaties of the Russian Federation" emphasizing that they confirm the commitment of the Russian Federation to the observance of treaties and customary norms, i.a. the principle of fulfilment of international obligations in good faith. It guides the courts and explains the terms "universally recognized principles and norms of international law", "international treaties", and requirements for direct application of a treaty norm ${ }^{214}$ such as publication, entry into force, need of implementing measures etc., ${ }^{215}$ the specificity of the application of international treaties in criminal cases, diplomatic immunities, the scope of primacy of international norms, the interpretation of a treaty on the basis of Articles 31-33 of the VCLT, and the obligations of the Russian judiciary stemming from the ECHR. ${ }^{216}$

followed the same pattern. The Court enacted several 'circulars' to render recommendations for lower Arbitrazh courts and general interpretative resolution "On the Implementation of the International Treaties of the Russian Federation Referring to the Questions of Arbitration Procedure" (11 June 1999). See S.Y. Marochkin, 'International Law in the Courts of the Russian Federation: Practice of Application' (2007) 6(2) Chinese Journal of International Law, pp. 331-332.

214 The Ruling of the Plenary Session of the Supreme Court of the Russian Federation no. 5 (n. 213) para. 3: "When considering civil, criminal or administrative cases, a court should directly apply such international treaties of the Russian Federation that entered into force and became binding for the Russian Federation, if their provisions do not require the adoption of national acts for their application and are capable of giving rise to rights and obligations for the subjects of national law (Part 4 of Article 15 of the Constitution of the Russian Federation, Parts 1 and 3 of Article 5 of Federal Law «On International Treaties of the Russian Federation», Part 2 of Article 7 of the Civil Code of the Russian Federation)."

215 These rules are quite detailed: " 5 . International treaties that have a direct and immediate effect in the legal system of the Russian Federation can be applied by the courts (including military courts) in the consideration of civil, criminal and administrative cases, in particular: in the consideration of civil cases, if an international treaty of the Russian Federation stipulates other rules than the law of the Russian Federation, regulating the relations that are the subject matter of proceedings; in the consideration of civil and criminal cases, if an international treaty of the Russian Federation stipulates other rules of judicial proceedings than the civil procedural or criminal procedural law of the Russian Federation; in the consideration of civil and criminal cases, if an international treaty of the Russian Federation regulates the relations, that are the subject matter of proceedings, including relations with foreign persons (e.g. in the consideration of cases listed in Article 402 of the Civil Procedure Code of the Russian Federation, motions for the enforcement of foreign court decisions, appeals against decisions on the extradition of individuals accused of committing a crime or convicted by a foreign court); in the consideration of cases on administrative offences, if an international treaty of the Russian Federation stipulates other rules than those stipulated in the legislation on administrative offences", ibidem.

216 See also the Ruling of the Plenary Session of the Supreme Court of the Russian Federation no. 21 "On the Application of the Convention for the Protection of Human Rights and Fundamental Freedoms of 4 November 1950 and Protocols thereto by the Courts of General 
It must be noted that the Ruling no. 5 in its 2003 version defined the term "universally recognized principles and norms of international law" in Art. 15(4) of the Constitution as amounting to jus cogens norms. It emphasised that the generally recognised principles of international law should be understood as the basic imperative norms of international law, accepted and recognized by the international community of States as a whole, deviation from which is inadmissible. ${ }^{217}$ Such norms include, but are not limited to, the principle of universal respect for human rights and fulfilment in good faith of obligations under international law. Other jus cogens norms may be found in particular in documents of the United Nations and its specialised agencies. ${ }^{218}$

As the practice evolved, the concept appears now broader as encompassing the norms of international customary law. ${ }^{219}$ For example, such conclusion may be drawn from the 2015 judgment in Inpredserwis $v$ The Consulate General of the Republic of Poland ${ }^{220}$ where the St. Petersburg Arbitrazh Court adjudicated on the execution of a rent for a house hosting the seat of the Consulate and the request to leave the building. The Court recognized that the action against the Consulate constitutes the action against the State and consequently, the norms on State immunity apply. The Arbitrazh Court noticed that, however, according to general rules of Russian law, Poland is entitled to immunity from Russian jurisdiction, but since under Art. 15(4) of the Constitution, generally recognised rules and principles of international law and treaties of the Russian Federation are the part of the Russian legal system the Court has to apply customary international law. ${ }^{221}$ The Court referred to the rules on

Jurisdiction" (27 June 2013), <http://www.supcourt.ru/catalog.php?c1=English\&c2=Documents\&c3=\&id=9155> (access: 25 September 2016).

217 Ibidem, para. 1. Cf. O.A. Ishchenko, E.G. Ishchenko, 'Implementation of International Law in Russian Legislation' (2008) 2 Russian Law: Theory and Practice 200.

218 According to para 16 of the Ruling: "[i]f courts encounter difficulties when interpreting the universally recognized principles and norms of international law or international treaties of the Russian Federation, it is recommended to them to use the acts and decisions of international organizations, including the United Nations and its specialized agencies, as well as to contact the Legal Department of the Ministry of Foreign Affairs of the Russian Federation and the Ministry of Justice of the Russian Federation (e.g. in order to clarify any issues regarding the duration of an international treaty, the list of states participating in the treaty, the international practice of its application)."

219 Cf. S.Yu. Marochkin, V.A. Popov, 'International Humanitarian and Human Rights Law in Russian Courts' (2011) 2 International Humanitarian Legal Studies, pp. 216-249. The authors observed: "In spite of the fact that the Supreme Court did not word the definition 'the generally recognized principles and norms' quite correctly, it offers guidelines to lower courts [...]", p. 230. See the literature and Russian case law cited therein.

220 Case A56-48129/2014 (3783/2015-44531(1)) (St. Petersburg Arbitrazh Court, 9 February 2015). The courts of arbitration deal in Russia with business and commercial matters.

221 On the approach of the Russian academia to the doctrine of absolute or restrictive State immunity see: L. Mälksoo, Theory of International Law in Contemporary Russia (Oxford University Press 2015), pp. 130-131. 
restrictive State immunity from jurisdiction in respect of commercial transaction enshrined in Art. 4 of the 1972 European Convention on State Immunity, Art. 2(1)(c) and Art. 10 of the 1991 ILC Draft Articles, and the 2004 United Nations Convention on Jurisdictional Immunities of States and Their Property (Art. 2(1)(c) and Art. 10) as well as the ECtHR decisions in Oleynikov $v$ Russia, Cudakv Lithuania, Sabeh El Leil v France and Wallishauser v Austria. The latter were invoked to argue that the ILC Draft Articles now reflected in the 2004 UN Convention are applicable as customary international law even if the concerned State has not ratified the Convention, as long as this State had not protested against the content of the Convention. The case certainly is an interesting follow-up to the ECtHR case law illustrating the use of the same method of determination of customary law as employed by the ECtHR decisions. But what is curious about the case is the way it classifies as a commercial transaction the rent of a public building administered by a State-owned company specifically established for the diplomatic and consular service and performed on the basis of the international agreement with Poland as a part of a broader deal. ${ }^{222}$

Despite of the disappointing practice, there are certainly good legal basis for the application of international law in Russian legal system. But as it appears much depends on judges ${ }^{223}$ and on the general attitude of the broader public, including scholars ${ }^{224}$ and politicians. There is still the opposition in all those groups, growing, as it seems, with the number of decisions passed by the ECtHR against Russia where the violation of the ECHR is found. ${ }^{225}$

222 See e.g. 'Rosyjski sąd zezwolił na udział komorników w eksmisji polskiego konsulatu' (Gazeta Wyborcza, 17 March 2015), <http://wyborcza.pl/1,75477,17582164,Rosyjski_sad_zezwolil_ na_udzial_komornikow_w_eksmisji.html\#ixzz3UezjHrrn> (access: 22 July 2016). On the bases of the same agreement the Russian Federation may use for diplomatic purposes several buildings situated mainly in Warsaw.

223 For example, the application of the ECHR by Russian courts in the period of 1998-2004 was very weak. Cf. A.L. Burkov, 'Implementation of the Convention for the Protection of Human Rights and Fundamental Freedoms in Russian Courts' (2006) 1 Russian Law: Theory and Practice, pp. 68-76. The author found that overall both the Supreme Court (there were 3,911 cases under scrutiny) and the Arbitrazh courts (38,068 cases) in practice have not invoked the ECHR at all (71). Out of the total of the Arbitrazh courts decisions, only 23 mentioned the ECHR, of which only 8 contained the specific reference to an Article of the Convention (there were no references to the ECtHR case law). In other 15 cases the courts only briefly cited the arguments of a party based on the ECHR. The worst examples, according to Burkov, were when a court stated that a particular act was not contrary to the ECHR as a whole (70-71); see also A. Burkov, 'Motivation for Direct Application of the Convention for the Protection of Human Rights and Fundamental Freedoms in Russian Courts' (2012), p. 12, Y.B. Baltic Int'I L. pp. 229-247.

224 There is still quite a number of scholars (the sovereigntist school) hostile towards the idea of direct application of international law. Cf. L. Mälksoo, Theory of International Law in Contemporary Russia (Oxford University Press 2015) 112.

$225 \mathrm{Cf}$. ibidem, p. 162. The reactions started to be more hostile towards the ECtHR after /laşcu v Moldova and Russia (App. no. 48787/99, 8 July 2004) where the ECtHR held Russia 


\subsection{Strong Dissenting Dialogue - the Answer to the ECtHR Markin and Anchugov Cases}

The execution of the ECtHR judgments passed against Russia seems to constitute a peak of the opposition to the interference of international law in domestic matters mentioned above. In 2013 the Russian Constitutional Court marked the boundaries on the competence of the Russian courts to apply international law, specifically the ECtHR judgments. ${ }^{226}$ The Constitutional Court ruling is a response to the 2012 Grand Chamber judgment of the ECtHR in Konstantin Markin $v$ Russia $^{227}$ in which the ECtHR found that Russia violated Art. 8 and Art. 14 ECHR denying a military serviceman a three-year parental leave to take care of his three children because under Russian law such leave could only be granted to the female military personnel. Previously in 2009, the Constitutional Court, relying on national security, declared the Law on the Status of Military Personnel and related laws to comply with the Constitution, especially with its Art. 19 on non-discrimination. ${ }^{228}$ In the 2010 Chamber judgment in Konstantin Markin v Russia the reasoning of the Russian Constitutional Court was described as 'unconvincing ${ }^{229}$ and founded upon 'gender prejudices', that is on the perception of women as primary child-carers and men as primary breadwinners. ${ }^{230}$ Further, the ECtHR recommended to amend Russian law with a view to putting an end to the discrimination against male military personnel as far as their entitlement to parental leave is concerned. ${ }^{231}$

responsible for the torture of a group of pro-Romanian Moldovan politicians in Transdnistria. The Russian Ministry of Foreign Affairs issued a statement condemning the ECtHR for a 'double standard' used against Russia. The statement reads: "In connection with the ruling on the 'case of Ilascu' Moscow expresses bewilderment at the inconsistency, contradictoriness, subjectivity and the obvious political engagement of the European Court of Human Rights in Strasbourg. Juridically this verdict, mildly speaking, is far from irreproachable." Statement by the Russian Ministry of Foreign Affairs FA (8 July 2004), <http://www.mid.ru/bdomp/brp_4.nsf/0/aedaea734e366074c3256ecb0054ed80> (access: 13 June 2015). The other 'difficult' cases dealt with by the ECtHR are: Catan and Others $v$ Moldova and Russia. App. no. 43370/04, 8252/05, 18454/06 (19 October 2012), Kononov v Latvia, App. no. 36376/04 (17 May 2010), Janowiec and Others v Russia, App. no. 55508/07 and 29520/09 (21 October 2013), OAO Neftyanaya Kompaniya YUKOS v Russia, App. no. 14902/04 (just satisfaction, 31 July 2014).

226 Cf. I.V. Vorontsova (n. 205); L. Mälksoo, 'Casenote on Markin v Russia' (2012) 106 American Journal of International Law, pp. 836-842; G. Vaypan, 'Acquiescence Affirmed, Its Limits Left Undefined: The Markin Judgment and the Pragmatism of the Russian Constitutional Court vis-à-vis the European Court of Human Rights' (2014) II(3) Russian Law Journal 130 et seqq.

227 Konstantin Markin v Russia, App. no. 30078/06 (ECtHR, 22 March 2012).

228 Case 187-0-0/2009 (Constitutional Court, 15 January 2009).

229 Konstatntin Markin v Russia, App. no. 30078/06 (ECtHR, 7 October 2010) para. 56.

230 Ibidem, para. 58.

$231 \mathrm{Ibidem}$, para. 67. 
The reaction from the Constitutional Court followed. Inter alia the President of the Court, Valery Zorkin, in an emotional article argued that the decision does not respect Russia's sovereignty and its legislature, the Strasbourg Court had even crossed the red line of Russia's sovereignty. ${ }^{232}$ Moreover, he warned that if Russia's "historical, cultural and social situation" were to be further ignored, Russia might be forced to bypass judgments of the ECtHR. ${ }^{233}$

In March 2012 the Grand Chamber of the ECtHR affirmed the Chamber judgment, however, it softened the rhetoric. In the atmosphere of strong reactions against the ECtHR decisions, the Supreme Court adopted on 27 June 2013 the Ruling no. 21 of the Plenary Session On Application of the Convention for the Protection of Human Rights and Fundamental Freedoms of 4 November 1950 and Protocols thereto by Courts of General Jurisdiction which confirmed that the decisions of the ECtHR are binding on general courts and these courts have to take into account the case law of the ECtHR.

In 2013 the Constitutional Court had another occasion to deal with Markin case, this time the petition for the reopening of procedure in his case as a consequence of the ECtHR's judgment. The Circuit Military Court in St. Petersburg asked the Constitutional Court for reconciliation in the light of the contradicting judgments by the Constitutional Court and the ECtHR. The Constitutional Court found that the common courts are obliged to reopen proceedings in connection with the ECtHR judgment. If, however, the court is not capable to enforce a decision without, at the same time, disregarding provisions of domestic law in the form of a binding interpretation of the Constitution rendered by the Constitutional Court, it must request the Constitutional Court to assess the constitutionality of such provisions. ${ }^{234}$ The Court observed that since, basically, the same rights and freedoms are provided for in the Russian Constitution and in the ECHR, the court faces the question of constitutionality of relevant domestic law provisions. Solely the Constitutional Court under the established case law could decide such question. ${ }^{235}$

In 2013 in Anchugov and Gladkov v Russia the ECtHR found the norm of the Russian Constitution to be incompatible with the Convention. The case concerned two prisoners convicted to the death penalty i.a. for murder. Their death sentence was then commuted to fifteen years' imprisonment. The applicants complained in particular that their disenfranchisement had violated their right to vote and had prevented them from participating in a number of elections. The ECtHR in line

232 V. Zorkin, 'The Limit of Giving In' ['Predel ustupchivosti'] Rossiiskaia gazeta (22 March 2010), <http://www.rg.ru/2010/10/29/zorkin.html> (access: 20 June 2016).

233 Cf. L. Mälksoo, 'Russia and European Human-Rights Law: Progress, Tensions and Perspectives', [in:] L. Mälksoo (ed.), Russia and European Human Rights Law: The Rise of the Civilizational Argument (Brill Nijhoff 2014), pp. 5-6.

234 Case 27-П/2013 (Constitutional Court, 6 December 2013), <https://rg.ru/2013/12/18/ks-dok. html> (access: 25 September 2016).

235 Ibidem, para. 3, 3.1. 
with its previous decisions in i.a. Hirst and Scopolla ${ }^{236}$ held that Russia's blanket ban on convicted prisoners' voting rights enshrined in Art. 32(3) of the Russian Constitution $^{237}$ was incompatible with the ECHR. ${ }^{238}$ Following Markin and Anchugov cases a group of deputies for the State Duma (the lower house of the Russian parliament) inquired the Constitutional Court on the enforcement of ECtHR judgments in Russia. In 2015 the Constitutional Court made it clear that the Constitution had a priority over the judgments, with the consequence that a decision from the ECtHR that contradicted the Russian Constitution could not be executed in Russia. ${ }^{239}$ The Constitutional Court stated that when the content of judgments of the ECtHR, including the part of prescriptions addressed to the respondent State and based on the provisions of the ECHR, interpreted by the ECtHR within the framework of a specific case, "unlawfully, from the constitutional-point of view, affect principles and norms of the Constitution of the Russian Federation, Russia may, as an exception, deviate from fulfilment of obligations imposed on it, when such deviation is the only possible way to avoid violation of fundamental principles and norms of the Constitution of the Russian Federation." 240 The Constitutional Court observed that the Vienna Convention on the Law of Treaties, namely Art. 26 on pacta sunt srevanda and Art. 31(1) on treaty interpretation, should be respected both by Russia and the ECtHR. The judgment of the ECtHR which applies the interpretation of the Convention exceeding the limits of the general rule of interpretation and diverging from imperative norms of customary law (such as the principle of sovereign equality and respect for rights inherent in sovereignty and the principle of non-interference with internal affairs of States) cannot be regarded as obligatory for execution. ${ }^{241}$

Moreover, the Constitutional Court referred to Art. 46 VCLT for authority that a State may block operation of separate provisions of international treaty in its respect, referring to the fact that the consent to obligatory character of this treaty was expressed by it in violation of one or another provisions of its internal law with regard to the competence to conclude treaties, if this violation was obvious and concerned a norm of internal law of a particular importance. In view of the Constitutional Court, the provisions of Chapters 1 and 2 of the Russian Constitution belong to such norms. Their alteration by means of constitutional amendments is not allowed. It may be carried out exclusively by adopting a new Constitution. ${ }^{42}$

236 Hirst v the United Kingdom (no. 2), App. no. 74025/01 (ECtHR, 6 October 2005); Scoppola v Italy (no. 3), App. no. 126/05 (ECtHR, 22 May 2012).

237 The provision reads: "citizens detained in a detention facility pursuant to a sentence imposed by a court shall not have the right to vote or to stand for election."

238 Anchugov and Gladkov v Russia, App. no. 11157/04 and 15162/05 (ECtHR, 4 July 2013).

239 Case 21-П/2015 (Constitutional Court, 14 July 2015) paras 2.2, 3, 4.

240 Ibidem, para. 2.2.

241 Ibidem, para. 3.

242 Ibidem. 
To support its findings the Constitutional Court referred to the well-known cases concerning other jurisdictions e.g. to the three decisions of the German Constitutional Court of 11 October 1985, 14 October 2004, 13 July 2010 indicating the limited legal force of the ECtHR judgments. The Russian Court emphasized that in particular when deciding on the execution of the ECtHR judgment in Görgulu $v$ Germany ${ }^{243}$, the German Constitutional Court formulated the principle of priority of the national constitution over the decisions of the ECtHR. The German Court noted that the ECHR is a part of the German federal law and has to be used for the interpretation of the provisions of the German Constitution on fundamental rights. ${ }^{244}$ The decisions of the ECtHR are not always obligatory. Domestic judges have to consider and carefully apply them to the internal legislation. A similar attitude, according to the Russian Constitutional Court, was taken earlier by the German Constitutional Court in reference to EU law in Solange-I judgment. ${ }^{245}$ The Russian Court noted as well the judgments of the Italian Constitutional Court, the first of 2012 disregarding the decision of the ECtHR in Maggio and others $v$ Italy (on trans-border pension payments) ${ }^{246}$ and the second one of 2014 regarding the ICJ judgment in Jurisdictional Immunities of the State. ${ }^{247}$ In both cases, as the Russian Court observed, the Italian Constitutional Court underlined that "the observance of international obligations may not be the reason of reduction of the level of protection of rights which has already been embedded in internal legal order." ${ }^{248}$ Furthermore the Russian Constitutional Court discussed the Austrian case ${ }^{249}$ and the decision of the Supreme Court of the United Kingdom $^{250}$ disregarding the ECtHR judgment - Hirst $v$ The UK (no. 2) on the voting rights of prisoners. ${ }^{251}$ They were invoked for the same authority that the decisions of the ECtHR are not perceived as binding in an absolute manner. They have only to be "taken into consideration". "It is deemed possible to follow these decisions only in the event if they do not contradict fundamental material and procedural norms of the national law." 252

In the other parts of the judgment the Constitutional Court discussed its own cases especially Markin and Anchugov. The latter lead, in the view of the Court, to a real conflict between the Constitution and the ECtHR's interpretation of the Convention. In a situation of a conflict the Constitutional Court feels entrusted

243 Görgulu v Germany, App. no. 74969/01 (ECtHR, 26 February 2004).

244 Case 2BvR 1481/04 (German Constitutional Court, 14 October 2004) para. 307.

245 Solange / 2 BvL 52/71 (German Constitutional Court, 29 May 1974) para. 271.

246 Case 264/2012 (Italian Constitutional Court, 19 November 2012); Maggio and others v Italy, App. no. 46286/09, 52851/08, 53727/08, 54486/08 and 56001/08 (ECtHR, 31 May 2011).

247 Case 238/2014 (Italian Constitutional Court, 22 October 2014); Jurisdictional Immunities of the State, Germany v Italy: Greece Intervening (ICJ, 3 February 2012).

248 Case 21-П/2015 (Constitutional Court, 14 July 2015) para. 4.

249 Case B267/86 (Constitutional Court, 14 October 1987).

250 Judgment of 16 October 2013 UKSC 62.

251 Hirst $v$ the United Kingdom (no. 2), App. no. 74025/01 (ECtHR, 6 October 2005).

252 Case 21-П/2015 (Constitutional Court, 14 July 2015) para. 4. 
by the Russian Constitution to resolve it and "in the extremely rare cases deems it appropriate to use 'the right to objection' for the sake of making its contribution (following colleagues from Austria, Great Britain, Germany and Italy) to the formation of balanced practice of the European Court of Human Rights, but not for the sake of self-isolation from its decisions, which reflects consensus worked out by States-parties to the Convention, but proceeding from the need of constructive interaction and mutually respectful dialogue with it."253

However, the Constitutional Court suggested also to the federal legislator to envisage a special legal mechanism of determination of the question of possibility or impossibility to execute the ECtHR judgment rendered against Russia. ${ }^{254}$

Following the decision of the Constitutional Court, the amendments to the 1994 Federal Constitutional Law "On the Constitutional Court of the Russian Federation" were adopted and entered into force on 15 December 2015. ${ }^{255}$ The amendments provide the Constitutional Court (which otherwise could only perform a constitutionality control over the treaties which have not yet entered into force $)^{256}$ with a new power to declare the decisions of international bodies dealing with the protection of human rights and freedoms as unenforceable at the request of the federal executive authority which has a competence to protect the interests of the Russian Federation before such courts or other bodies. $^{257}$

The solution adopted by Russia is unique. No other member of the Council of Europe has conferred such powers on a national court. Under the 2015 law, if the Constitutional Court declares a ruling unenforceable, no steps to implement

253 Case 21-П/2015 (Constitutional Court, 14 July 2015) para. 6. Venice Commission, English translation after Interim Opinion on the amendments to the Federal Constitutional Law on the Constitutional Court of the Russian Federation, CDL-AD(2016)005-e (106 ${ }^{\text {th }}$ Plenary Session, Venice, 11-12 March 2016), <http://www.venice.coe.int/webforms/documents/default. aspx?pdffile=CDL-AD(2016)005-e> (access: 25 September 2016), para. 26.

254 Ibidem.

255 The Federal Law no. 7-KFZ (CDL-REF(2016)006 introducing amendments to the Federal Constitutional Law no 1-FKZ of 21 July 1994 "On the Constitutional Court of the Russian Federation" (CDL-REF(2016)007 was passed by the State Duma on 4 December 2015, ratified by the Federation Council on 9 December, signed by the President on 14 December and published the following day). The law entered into force on 15 December 2015. It was adopted a year after the ECtHR ordered Russia to pay 1.87 billion euro in compensation to shareholders of the oil company Yukos for violation of their property rights when the company went bankrupt (OAO Neftyanaya kompaniya YUKOS v Russia, App. no. 14902/04 (ECtHR, 24 June 2014)).

256 Article 125(2)(d) of the Constitution and Art. 3(1)(1)(d) of the Federal Constitutional Law "On the Constitutional Court of the Russian Federation" prohibits the constitutionality control of a treaty already in force for the Russian Federation.

257 The competence is based on Art. 79 of the Constitution, which authorizes the accession of the Federation to international organization only if the compliance with the constitutional rights and freedoms and the basic fundamental principles is ensured. 
the ruling can be taken (both general and individual measures of execution) unless the Constitution is amended. ${ }^{258}$

The decision of the Constitutional Court and the new law of 2015 are not the only examples of the strong dissenting dialogue of the State organs with the ECtHR but certainly the strongest one. The saga is not over as in 2016 the Constitutional Court invoked its new powers deciding upon the request of the Ministry of Foreign Affairs that the ECtHR's ruling on Anchugov and Gladkov $v$ Russia cannot be implemented with regard to the measures of general character contemplating the amendments to Russia's legislation which would allow to restrict electoral rights not of all prisoners. This would be contrary to the absolute ban enshrined in Art. 32(3) of the Constitution. ${ }^{259}$ The Constitutional Court's judgment is based on the arguments of State sovereignty, supremacy of the Constitution, control of the scope of the consent given by the State to be bound by the treaty and subsidiary role of the ECtHR. It contains detailed discussion of the relevant domestic decisions of the ECHR's State parties and the ECtHR case law. The Constitutional Court repeated that "if it deems it necessary to enjoy the right to objection as an exceptional case, it is only in order to make contribution to the crystallization of the developing practice of the European Court of Human Rights in the field of suffrage protection, whose decisions are called upon to reflect the consensus having formed among States Parties to the Convention." ${ }^{260}$ The Court assured that it recognizes the objective necessity of the ECtHR's need to identify structural defects of national legal systems and to suggest the ways to remove them. But the Constitutional Court also considered problems connected with possible

258 On 15 March 2016, the European Commission for Democracy through Law (Venice Commission) adopted "Interim Opinion on the Amendments to the Federal Constitutional Law on the Constitutional Court of the Russian Federation." It found the law of 2015 contrary to Art. 26 and Art. 27 VCLT and Art. 46 ECHR. The Commission emphasized that the State as a whole (all State organs) is bound to respect international treaties binding upon it and it cannot invoke a norm of its internal law to justify its failure to perform according to a treaty (in this case the ECHR). Under Art. 46 ECHR the State is bound by the interpretation of the Convention given by the ECtHR. The State has to execute the judgment, only the modality of execution is at States' discretion, however, not unfettered. The Russian Federation should have recourse to dialogue, instead of resorting to unilateral measures, which are at variance with Art. 31 VCLT, which stipulates that a State has to interpret the treaty 'in good faith'.(Opinion no. 832/2015, CDL- AD(2016)005, paras 96-100). See also Final Opinion no. 832/2015 of 10-11 June 2016 on the amendments to the Federal Constitutional Law of the Constitutional Court.

259 Case 12-ח/2016 (Constitutional Court, 19 April 2016) "On the resolution of the question of possibility to execute the Judgment of the European Court of Human Rights of 4 July 2013 in the case of Anchugov and Gladkov v Russia in accordance with the Constitution of the Russian Federation in respect to the request of the Ministry of Justice of the Russian Federation." Venice Commission, 'Judgement No. 12-П/2016 of 19 April 2016 of the Constitutional Court', <http:// www.venice.coe.int/webforms/documents/default.aspx?pdffile=CDL-REF(2016)033-e> (access: 24 September 2016).

260 Ibidem, para. 4.4. 
deviations from the principle of subsidiarity, on the basis of which the ECtHR is called upon to exercise its powers. ${ }^{261}$ The main problem for the Constitutional Court was, as it seems, the lack of competence of the ECtHR to give the ruling in abstracto. The task of the ECtHR in that particular case was, in the opinion of the Constitutional Court, not to review, in abstracto, the compatibility of Art. 32(3) of the Constitution with the Convention but to determine, in concreto, the effect of those provisions on the applicants' rights secured by Art. 3 of Protocol No. 1 to the Convention. The Constitutional Court noted that starting from standards established by the ECtHR itself, disenfranchisement for serious crimes that is, crimes punishable by three or more years of imprisonment, does not violate the principle of proportionality. That was exactly the case of Mr. Anchugov and Mr. Gladkov who were sentenced to fifteen years of imprisonment (as commutation of death sentences) for particularly grave crimes. Consequently, their rights guaranteed by Article 3 of Protocol No. 1 had not been infringed upon. Therefore, in that sense the judgment in their case is essentially the act of an in abstracto review of a norm exercised by the ECtHR. ${ }^{262}$

Those developments indicate that Russian judges are well prepared to adjudicate on international law issues but also that they use international law as a political tool. That occurred in Inpredserwis $v$ The Consulate General of the Republic of Poland and in Markin and Anchugov saga. The selective application of international law seems also characteristic for Russia. International law is applied to the extent it suites the case, e.g. to focus attention on formal, less important issues, instead than on the substance of the case. We will illustrate this phenomenon invoking the Crimea case in which the judges of the Constitutional Court justified the Russian aggression on the territory of Ukraine.

\subsection{The Vienna Convention on the Law of Treaties and Politics - the Crimea Case}

The decision of the Constitutional Court of 2014 concerning Crimea is a landmark historic judgment ${ }^{263}$ however, not on account of the development of international law, which it could have marked. The Constitutional Court decided on the 'accession' to the Russian Federation, as Russian judges called it, not on an 'illegal annexation' on 18 March 2014 of the Autonomous Republic of Crimea and the city of Sevastopol. The act constituted an illegal annexation in the opinion i.a. of one hundred States, which, from the beginning, condemned

261 Ibidem, para. 5.5.

262 Ibidem, para. 6.

263 Case 6-П/2014 (Constitutional Court, 19 March 2014) "On the verification of the constitutionality of the international treaty, which has not yet entered into force, between the Russian Federation and the Republic of Crimea on the accession of the Republic of Crimea to the Russian Federation and the formation of new constituent entities within the Russian Federation." 
Russian activities on the Ukrainian territory and subsequently supported the UN GA resolution 68/262 of 27 March 2014. ${ }^{264}$ The Resolution entitled "Territorial integrity of Ukraine" affirmed the UN GA commitment to the sovereignty, political independence, unity and territorial integrity of Ukraine within its internationally recognized borders and underscored invalidity of the Crimean referendum held on 16 March 2014. Furthermore, the judgment did not take into account that few days earlier the Constitutional Court of Ukraine had declared unconstitutional The Resolution of the Verkhovna Rada of the Autonomous Republic of Crimea No. 1702-6/14 "On holding of the all-Crimean referendum" of 6 March $2014 .^{265}$

The decision of the Constitutional Court concerns only the procedure to conclude the treaty and legal effects of a clause on provisional application of this treaty. The title of the judgment sounds quite innocent: "On the verification of the constitutionality of the international treaty, which has not yet entered into force, between the Russian Federation and the Republic of Crimea on the accession of the Republic of Crimea to the Russian Federation and the formation of new constituent entities within the Russian Federation." In reality the Constitutional Court was to confirm legality of the annexation of Crimea deciding on the date when 'the accession' became effective. The Court dealt with the case i.a. on the basis of the Vienna Convention of the Law of Treaties selecting from it only the provisions on the procedure and the form and leaving out the consideration of the treaty making powers in Crimea or the substance of a treaty (if international law is indeed part of Russia's

264 A/RES/68/262. Cf. e.g. "The Opinion of the Legal Advisory Committee to the Minister of Foreign Affairs of the Republic of Poland on the annexation of the Crimean Peninsula to the Russian Federation in light of international law" (22 June 2014), <http://www.msz.gov.pl/resource/d93bc452-c276-4f5a-8551-a04464c6b202:JCR> (access: 21 July 2016).

265 Case 2-rp/2014 (Constitutional Court of Ukraine, 14 March 2014). The Court observed that the Ruling contradicts not only the Constitution of Ukraine but "also the fundamental principles of sovereignty and territorial integrity of a state, constituted in international law instruments, in particular the principle of mutual respect for the sovereign equality of each state including political independence, the ability to change the borders under international law by peaceful means and by agreement. As a result of these principles States Parties shall refrain from violation of territorial integrity or political independence of any state by use of force or threat of force or other manner inconsistent with the purposes of the United Nations, as well as actions directed against the territorial integrity or unity of any State Party (The United Nations Charter, the Final Act of Conference on Security and Cooperation in Europe of 1975, the Framework Convention the Protection of National Minorities of 1995)", para. 4.5. English translation: Ministry of Foreign Affairs, 'Judgement of the Constitutional Court of Ukraine on all-Crimean Referendum' (15 March 2014), <http://mfa.gov.ua/en/newsfeeds/foreign-offices-news/19573-rishennya-konstitucijnogo-sudu-v-ukrajini-shhodo-referendumu-v-krimu> (access: 26 September 2016). In case 3-rp/2014 (Constitutional Court of Ukraine, 20 March 2014) the Court found the resolution of the parliament of Crimea on 'declaration of independence' of 11 March 2014 to be contrary to the Constitution and to the UN Charter (principle of self-determination). 
legal system, the Court should have elaborated on the compatibility of the accession/annexation with the UN Charter).

The Constitutional Court avoided any references to international law especially the UN Charter or the ICJ's case law, except for the law of treaties. In that sense the decision is the example of a failed dialogue.

The Constitutional Court found the Agreement on the accession of the Republic of Crimea to the Russian Federation of 18 March 2014 in compliance with the Russian Constitution in terms of procedure of signing, conclusion and entry into force of a treaty, separation of State power into legislative, executive and judicial, delimitation of competence between federal State organs and content of its norms. As far as the law of treaties is concerned, the Constitutional Court took for granted that the document signed by the President of the Russian Federation constitutes an international treaty. It did not examine the Agreement in terms of powers of the other party. The Court had to assess constitutionality of Art. 1 and Art. 10 of the Agreement. Under Art. 1(1) of the Agreement the Republic of Crimea becomes the member of the Russian Federation on the date of the signing of the Agreement. Article 10 provides for the Agreement to be provisionally applied and to enter into force on the date of ratification. The Constitutional Court observed that the accession of Crimea to the Russian Federation took place following the procedure of the ratification of a treaty. The procedure complies, first of all, with the VCLT which in Art. 25 confirms that a treaty may be provisionally applied pending its entry into force. The Court noted that also the Russian law authorises the provisional application of a treaty (Art. 23 of Federal Law of 15 July 1995 no. 101-FZ "On International Treaties of the Russian Federation") and invoked for support its 2012 judgment. ${ }^{266}$ In the judgment the Court emphasised that the Russian Federation may agree to the provisional application of treaties, if the subject matter of a treaty is of special interest to its parties and because of that interest the parties wish to give effect to its provisions not waiting for its ratification and entry into force. Since the provisional application of the Agreement complies both with international and domestic law, Crimea acceded to the Russian Federation on 18 March $2014 .^{267}$

It is interesting to note that the decision of the Constitutional Court provoked strong reactions of the other European constitutional courts. On the initiative of the Constitutional Court of Ukraine the "Joint Statement on respect for the territorial integrity and international law in administering constitutional justice" was adopted and signed by the presidents of the constitutional courts i.a. of Lithuania, Georgia, Moldova, Poland, Ukraine, Cyprus, Azerbaijan. The Joint Statement labelled the role of the Russian Constitutional Court as unprecedented, condemning the Court for taking part in the annexation of Crimea and violating international

266 Case 8-П/2012 (Constitutional Court, 27 March 2012).

267 Case 6-П/2014 (Constitutional Court, 19 March 2014) para. 3. 
law also by recognizing the Republic of Crimea as a legal entity and the Agreement as an international treaty. ${ }^{268}$

The case illustrates as well that the dialogue between judges may take different forms and is much easier nowadays i.a. due to the development of different forms of cooperation between judges, including e.g. the Conference of European Constitutional Courts.

\section{Ukraine}

\subsection{The Legal Setting for Judicial Dialogue}

Two studies in this volume are devoted to the application of international law in Ukraine (see further in this volume Kolysnik, Tsymbrivskyy). That is why here we will only emphasize some aspects characteristic for the judicial dialogue from the perspective of this country. Ukraine is a former Soviet Republic. After the World War II it was granted a limited power to partake in international relations including international treaties making. This power was obviously based on the Soviet concept of the relationship between international and municipal law.

The country gained independence in 1991 and in 1996 adopted its Constitution. The provisions of the Ukrainian Constitution on international law resemble the provisions of the Russian Constitution, but seem narrower - they refer to a specific category of treaties as a part of the Ukrainian legislation (not the Ukrainian legal system) and lack references to the universally recognized principles of international law. However, Art. 18 of the Ukrainian Constitution refers to the respect of the generally acknowledged principles and norms of international law. Yet, this provision concerns only external relations. ${ }^{269}$ Article 9 of the Ukrainian Constitution addresses only treaties and provides that:

268 JointStatementConcerning RespectforTerritorial Integrity and International Law in Administering Constitutional Justice, <http://www.lrkt.lt/en/news/other-news/the-president-of-the-constitutional-court-supports-the-initiative-of-the-constitutional-court-of-ukraine-at-the-conference-of-european-constitutional-courts-to-condemn-the-annexation-of-the-crimea/471> (access: 15 June 2016).

269 Art. 18 of the Constitution reads: "The foreign political activity of Ukraine is aimed at ensuring its national interests and security by maintaining peaceful and mutually beneficial co-operation with members of the international community, according to generally acknowledged principles and norms of international law." English version: Council of Europe, 'The Ukrainian Constitution', <http://www.coe.int/t/dghl/cooperation/ccpe/profiles/ukraineConstitution_ en.asp> (access: 25 September 2016). 
International treaties that are in force, agreed to be binding by the Verkhovna Rada of Ukraine, are part of the national legislation of Ukraine. The conclusion of international treaties that contravene the Constitution of Ukraine is possible only after introducing relevant amendments to the Constitution of Ukraine..$^{270}$

The Constitution mentions expressly only treaties ratified by the President upon the prior consent of the Parliament (the Verchovna Rada) and is silent on other treaties and customary international law. It has been therefore up to the judges to infer the authorisation to apply them from other provisions of the Constitution..$^{271}$

The first step in the process seems to be the 2001 opinion of the Ukrainian Constitutional Court on compliance with the Constitution of the Rome Statute of the International Criminal Court (ICC). The Constitutional Court rejected the argument that Art. 27 of the Rome Statute on irrelevance of official capacity for the jurisdiction of the ICC violates the constitutional provisions on immunities of the MPs, the President of Ukraine and the judges. The Court cited Art. 18 of the Constitution and indicated pacta sunt servanda principle as an example of generally recognized principles of international law. Then the Court emphasized that Ukraine is bound by various international treaties providing for responsibility for crimes laid down in the Rome Statute and the prohibitions of such crimes are also regarded as customary norms of international law. The Court observed that the crimes' "criminal nature according to Article 18 of the Constitution of Ukraine is not dependent on accession of Ukraine to the Statute and its entering into force."272 The judgment implies that Ukraine is bound by customary law and this law has to be taken into account by the judges.

There are no other judgments of the Constitutional Court on customary international law and there exist no relevant guidelines for the judges. Moreover,

270 Ibidem.

271 Some Ukrainian scholars are of the opinion that the Act of Declaration of the Independence of Ukraine of 24 August 1991 and the Declaration on State Sovereignty of Ukraine of 16 July 1990 , have to be taken into consideration in that regard. The preamble to the Constitution refers to the Act of 1991 (which in its turn is adopted "[i]n view of [...] implementing the Declaration of State Sovereignty of Ukraine"). The preamble reads: "The Verkhovna Rada of Ukraine, on behalf of the Ukrainian people - citizens of Ukraine of all nationalities, [...] guided by the Act of Declaration of the Independence of Ukraine of 24 August 1991, approved by the national vote of 1 December 1991, adopts this Constitution - the Fundamental Law of Ukraine." The 1990 Act contains a number of references to international law, both in general terms and to specific principles of international law and international agreements. The most important is as follows: "The Ukrainian SSR recognizes the prevalence of general human values over class values and the priority of generally recognised norms of international law over the norms of domestic law" (R. Khorolskyy, 'Country Report Ukraine' para. I.1, citing i.a. M. Buromenskyy, International Law: Manual for students [in Ukrainian] (Kharkiv 2005), pp. 73-79). Khorolskyy suggests that the Constitutional Court does not share this opinion.

272 Opinion on the conformity of the Rome Statute with the Constitution of Ukraine, Case 3-в/2001 (Constitutional Court, 11 July 2001) para. 2.2. 
the law is in that respect ambiguous. Some laws provide for application of customary law but they restrict references e.g. to international commercial customs ${ }^{273}$ or customs of merchant shipping. ${ }^{274}$ The ambiguity is growing if one notes the deletion in 2010 of the reference to "international customs that are recognized in Ukraine" as applicable law from Art. 4 of the Law on international private law. ${ }^{275}$ The reasons for such amendment are not known; the preparatory materials only mentioned the objection of the parliamentary legislative. ${ }^{276}$ In such situation it is not astonishing that ordinary courts do not apply international customary law. ${ }^{277}$

The legal position of the treaties other than referred to in Art. 9 of the Constitution is also not clear. In line with Art. 151 of the Constitution it seems that the Constitutional Court may review constitutionality of all the treaties in force or those which had been submitted to the Verchovna Rada for consent. ${ }^{278}$ Besides, the Constitution refers once to international treaties of Ukraine and on other occasions to treaties "ratified" by the Verchovna Rada. ${ }^{279}$ In 2004 Ukraine attempted to clarify this ambiguous regulation and adopted the Law on international treaties of Ukraine, the act replaced previous regulations. ${ }^{280}$ The Law distinguishes between treaties concluded by the President, the Government or ministers. It defines different procedures for their conclusion but it also contains the provision on legal effects of treaties in domestic law. Art. 19 (1) specifies that treaties in force concluded with consent of the Verkhovna Rada are a part of domestic law and "apply in a manner consistent to the norms of national legislation". 281 In case of conflict with domestic law, the treaty norm prevails.

The language of the provision remains ambiguous. Furthermore, as in Russia, in Ukrainian system there are separate endorsements of international law

273 Art. 4(5) of the Commercial Procedural Code of Ukraine, Law no. 1798-XII (6 November 1991).

274 Art. 6 of the Code of Merchant Shipping of Ukraine, Law no. 176/95-BP (23 May 1995).

275 The Law of Ukraine no. 2709-IV (23 June 2005) amended by the Law no. 1837-VI "On Amendments to Certain Legislative Acts of Ukraine concerning regulation of issues of private international law" (21 January 2010).

276 Cited by Khorolskyy R. (n. 7).

277 Ibidem, para. III.13.

278 Art. 151 of the Constitution reads: "The Constitutional Court of Ukraine, on the appeal of the President of Ukraine or the Cabinet of Ministers of Ukraine, provides opinions on the conformity with the Constitution of Ukraine of international treaties of Ukraine that are in force, or the international treaties submitted to the Verkhovna Rada of Ukraine for granting agreement on their binding nature." Text available at <http://www.coe.int/t/dghl/cooperation/ ccpe/profiles/ukraineConstitution_en.asp> (access: 25 September 2016).

279 See e.g. Art. 26, Art. 85(32), Art. 106(3), Art. XV of the Constitution.

280 The Law of Ukraine no 1906-IV (29 June 2004). The Act replaced two previous acts: "On Effect of International Treaties on the Territory of Ukraine" of 1992 and "On International Treaties of Ukraine" of 1994.

281 Text available at <http://zakon3.rada.gov.ua/laws/show/1906-15> (access: 25 September 2016); “і застосовуються у порядку, передбаченому для норм національного законодавства." 
in civil, criminal, administrative, commercial procedural laws regulating application of various sources of international law, their legal effects, reopening of proceedings following decisions of international courts etc. All these codes refer only to treaties "consent to which binding character was granted by the Verkhovna Rada of Ukraine". ${ }^{282}$ The position of other treaties than ratified upon consent of the Parliament is still not clear.

Accordingly, the provisions of Ukrainian law on application of international law do not establish neither a clear, nor a friendly legal basis for Ukrainian judges to apply and interpret international law. The commentators concordantly indicate the reluctance of Ukrainian judges to apply international law. ${ }^{283}$ They connect it with general problems within the judiciary, e.g. deficiencies in legal training of judges, but also signal the progress achieved i.a. owing to the US involvement ${ }^{284}$ and the EU aid in the reform of the Ukrainian judiciary of 2010 (i.a. administrative courts were established and an electronic database holding all national court decisions was created) and the development of the various forms of cooperation including judicial cooperation. ${ }^{285}$

\subsection{The Birth of Judicial Dialogue in Ukraine}

In 2011 R. Petrov and P. Kalinichenko observed that:

Ukrainian courts refer mainly to international agreements which are duly signed and ratified by the Ukrainian Parliament (Verkhovna Rada) and which are self-executing within the Ukrainian legal system. Even in these cases, the correct application of international

282 The formula reflects Art. 85(32) of the Constitution. Art. 2, Art. 8 of the Civil Procedural Code of Ukraine, Law no. 1618-IV (18 March 2004); Art. 1, Art. 9 the Criminal Procedural Code of Ukraine, Law no. 4651-VI (13 April 2012); Art. 4 of the Commercial Procedural Code of Ukraine, Law no. 1798-XII (6 November 1991; Art. 5, Art. 9 of the Code of Administrative Proceedings of Ukraine, Law no. 2747-IV (6 July 2005).

283 R. Petrov, P. Kalinichenko, 'The Europeanization of Third Country Judiciaries through the Application of the EU Acquis: The Cases of Russia and Ukraine' (2011) 60 International and Comparative Law Quarterly 344.

284 N. Prescott, 'Orange Revolution in Red, White and Blue: US Impact on the 2004 Ukrainian Election' (2006) 16 Duke Journal of Comparative \& International Law 238.

285 R. Petrov, P. Kalinichenko (n. 284), pp. 330-331. The authors observe that "these changes have not altered the reputation of the Ukrainian judiciary as one of the most corrupt institutions in the country. EU experts warn that the Ukrainian judiciary faces serious problems in the quality and substance of the legal training of its judges, as well as their regular professional training and funding. As a result, judicial decisions in Ukraine do not always comply with rule of law standards, and are often made arbitrarily. Independent surveys show an alarming level of widespread corruption among judges ( 40 per cent of judges admitted having been offered bribes - there are no statistics on judges admitted having been taken bribes in Ukraine and Russia). As a consequence, the majority of Ukrainians do not have trust in the judicial system, but consider it corrupt, politically biased and non-transparent", ibidem. 
agreements is not guaranteed, since one of the most important impediments for the application of international law by the Ukrainian judiciary is the correct understanding of these international conventions by national judges. International and European organizations realize this problem and target their assistance towards eliminating the incorrect application of international and European law by Ukrainian judges. This has led to the rise of judicial activism among Ukrainian judges in the "post-Orange Revolution" period, such as in the Yuschchenko, where the Ukrainian Supreme Court opened a door for Ukrainian courts to apply the judgments of other international tribunals and courts. ${ }^{286}$

The 2004 judgment of the Ukrainian Supreme Court in Yuschenko v Central Election Committee of Ukraine ${ }^{287}$ is probably not the first case in which Ukrainian courts relied on foreign and international decisions but certainly it is an important judgment for democracy in Ukraine. ${ }^{288}$ The decision is deeply rooted in the US jurisprudence (Bush $v$ Gore, Marbury $v$ Madison), ${ }^{289}$ which was certainly known to the judges who had participated before in various seminars and trainings organised with the US support. ${ }^{290}$ Since the US Court decisions are not mentioned in the judgment, the case is as an example of a silent dialogue. It concerned the results of the second round of the 2004 presidential election in Ukraine. The election was won by a narrow margin by Yanukovych but numerous factors indicated that his victory was gained through fabrication of results, allowing many individuals to vote twice, through threats and coercion, not mentioning, as appeared at the later stage, poisoning with dioxin of the counter-candidate - Yushchenko.

Yushchenko appealed to the Ukrainian Supreme Court claiming violations of the election laws and asking the Court for an injunctive and a declaratory relief. In its response the Supreme Court recalled that it may control the acts of the government (in that respect i.a. the case is compared to Marbury v Madison ${ }^{291}$ )

286 R. Petrov, P. Kalinichenko (n. 284), p. 344. Repeated in P. Van Elsuwege, R. Petrov, Legislative Approximation and Application of EU law in the Eastern Neighbourhood of the European Union, Toward a Common Regulatory Space (Routledge 2014), p. 147.

287 Yushchenko v Central Election Committee of Ukraine (Supreme Court, 3 December 2004). See: N. Prescott (n. 285), pp. 219-248.

288 E.g. case 11-rp/99 (Constitutional Court, 29 December 1999) on death penalty, cited below.

289 Respectivly, Bush v Gore 531 U.S. 98 (2000), Marbury v Madison 5 U.S. (1 Cranch) 137 (1803), p. 178. The latter case triggered the development of the American model of constitutional review performed by ordinary courts.

290 N. Prescott (n. 285), p. 240, see also p. 233. The author on page 244 underlines that "The United States prepared Ukraine for cases like Yushchenko by helping Ukraine shape its Constitution, by assisting the judges in issuing unbiased decisions, and by encouraging the Ukrainian Supreme Court to assert its Marbury v Madison power."

291 The case is important also for the determination of the role of the court: "It is emphatically the province and duty of the judicial department to say what the law is. Those who apply the rule to particular cases, must of necessity expound and interpret that rule. If two laws conflict with each other, the courts must decide on the operation of each." Marbury $v$ Madison, op. cit., p. 177. 
and has the power to influence the outcome of the elections (in that respect the case is compared to Bush v Gore). It was the first time for the Ukrainian Supreme Court to assert its power to interpret the election laws and the Constitution and to adjudicate on the validity of election, including its conformity with the Constitution. Moreover, it exercised its power of judicial review independently from the Constitutional Court (the Supreme Court had not referred the case to the Constitutional Court). The Court found the election invalid and ordered the runoff. ${ }^{292}$

The Ukrainian judges are still reluctant to rely on foreign and international decisions. ${ }^{293}$ In 2003 Wilkinson identified main reasons for such situation: the lack of translation of international case law and jurisprudence into Ukrainian to help judges to adapt their decisions to the best European standards, the delays in adapting national legislation to ratified treaties, and - the most important - the belief that international case law is not relevant to civil law systems. ${ }^{294}$ In that respect, he also pointed to the lack of proper Ukrainian term for case law. The closest Ukrainian word, yurisprudentsiya, signifies only the philosophy of law, and not the judicial precedents. The translators sometimes use the term yurisdichna praktika. But this term in Ukrainian law is only meant to be descriptive, not emphasizing the legal force of jurisprudence constante. In other words, the Ukrainian judges were not acquainted with the doctrine, which assumes that the judge should give weight to a rule that is accepted and applied in a long line of cases, and should not overrule or modify its own decisions without serious reasons. Instead, the judges have been guided in the application of selected statutes by the Supreme Court's plenum resolutions (orders), which are binding. ${ }^{295}$

Thanks to international support at least some of these reasons seem nowadays to be, to a certain extent, overcome (accessible translations of cases, better knowledge of case law owing to legal trainings etc.). However, the most difficult barriers, the long lasting habits, are still impeding application of foreign and international courts' decisions. It is interesting to note that in 2013 in the Report for the XVI ${ }^{\text {th }}$ Congress of the Conference of European Constitutional Courts, the Constitutional Court of Ukraine justified its reluctance in referring to the decisions from other jurisdictions by 'objective reasons'. The most important one seems to be still the perception of the role of case law in continental law systems:

The Constitutional Court of Ukraine has not referred to the jurisprudence of the constitutional courts of foreign countries in its decisions, which may be viewed as the result of objective factors. One of them is related to the legal nature and legal consequences of its

292 Yuschenko v Central Election Committee of Ukraine (Supreme Court, 3 December 2004).

293 R. Petrov, P. Kalinichenko (n. 284), p. 344.

294 D. Wilkinson, 'Interpreting Ukrainian legislation in light of international law and jurisprudence', НАУКОВІ ЗАПИСКИ, Том 22, Частина II, УДК 341.231.14, pp. 224-225.

295 Ibidem, p. 224. 
decisions. Since the latter in accordance with the Constitution of Ukraine (Article 150) shall be binding on the territory of Ukraine, it is legally impermissible to refer to the legal sources which are not obligatory for our country in the text. Another factor is determined by the fact that the Ukrainian legal system belongs to the Roman-Germanic legal family, in which the case-law (jurisprudence) historically has not played such a role, as in the countries of Anglo-Saxon legal family (common law system). At the same time, in examining cases the Constitutional Court of Ukraine takes into account the foreign practice of constitutional justice regarding relevant issues. References to the legal positions of constitutional courts of other countries may be found in dissenting opinions of judges of the Constitutional Court of Ukraine. ${ }^{296}$

Against this background, it is not surprising that in most cases in which the Ukrainian judges rely on foreign or international jurisprudence, this fact is not expressly mentioned (silent dialogue). Similarly, it becomes understandable why it was necessary in Ukraine to adopt a clear obligation to follow the ECtHR case law. In fact, the Law "On execution of decisions and application of case law [in Ukrainian - practice] of the European Court of Human Rights" was adopted in 2006. ${ }^{297}$

The Constitutional Court confirmed the use of silent dialogue and indicated that the effect of the ECtHR case law for the first time was recognised by it in the decision of 1999 on death penalty. ${ }^{298}$ The Constitutional Court admitted that it avoided direct reference to the ECtHR judgment in Soering $v$ United Kingdom but that it was highly influenced by it. ${ }^{299}$ The Court confirmed that it transplanted i.a. the concept of the rule of law from the ECtHR case law with such elements as justice, certainty, clarity and unambiguousness of legal norm, principle of proportionality, and principle of trust of citizens in the State. ${ }^{300}$ In recent years, the Constitutional Court refers not only more frequently to the ECtHR case law, but also indicates specific decisions.

For example, in 2015 the Constitutional Court broadly referred to the ECtHR case law to review the constitutionality of the provisions of the Code of Administrative Proceedings providing for one instance proceedings in certain administrative law cases. ${ }^{301}$ The Court discussed carefully the European standard of the right

296 The Report of the Constitutional Court of Ukraine for the XVIth Congress of the Conference of European Constitutional Courts "Cooperation of Constitutional Courts in Europe - Current Situation and Perspectives" (Constitutional Court, 2013), <https://www.vfgh.gv.at/ cms/vfgh-kongress/downloads/landesberichte/LB-Ukraine-EN.pdf> (access: 10 July 2016), para. II.1.23.

297 Law of Ukraine no. 3477-IV of February 2006.

298 Case 11-rp/99 (Constitutional Court, 29 December 1999).

299 The Report of the Constitutional Court of Ukraine (n. 297); case Soering v United Kingdom, App. no. 14038/88 (ECtHR, 7 July 1989).

300 E.g. cases of the Constitutional Court: 15-rp/2004 (2 November 2004), 3-rp/2003 (30 January 2003), 5-rp/2005 (22 September 2005), 6-rp/2007 (9 July 2007), 16-rp/2012 (29 August 2012), 8-rp/2010 (11 March 2010).

301 Case 3-rp/2015 (Constitutional Court, 8 April 2015). 
to a fair trial. It observed first that the ECHR does not oblige States to establish courts of appeal or cassation, nevertheless, a State, which does institute such courts is required to ensure that persons amenable to the law shall enjoy before these courts the fundamental guarantees contained in Art. 6. The Constitutional Court referred for authority to specific paragraphs of the ECtHR judgments in Delcourt $v$ Belgium and Hoffmann $v$ Germany. ${ }^{302}$ The Court then underlined that the right to judicial protection includes, in particular, a possibility to challenge court decisions in appeal and cassation, which is one of the constitutional guarantees of implementation of rights and freedoms, their protection from violations and illegal encroachments, including from false and unjust judgments. ${ }^{303}$

Furthermore, the Constitutional Court, when referring to para. 57 of Ashendon $v$ the United Kingdom of 28 May 1985 (the name of the case is incorrect and it is difficult to establish which case the Court wanted to indicate) and Krombach $v$ France, established the constitutional standard for a permitted restriction to the right to appeal or submission of a case for cassation conforming to the ECHR standard (whilst a right can be restricted by law, the restriction must pursue a legitimate aim, and not infringe upon the very essence of the right to a fair trial, and there should be a proportionate correlation between that aim and introduced measures). ${ }^{304}$ On such basis the Constitutional Court found the provisions under review to be disproportionate.

In the mentioned above 2013 Report, the Court reported many detailed references in its own decisions to the ECHR and other treaties and e.g. to the Council of Europe recommendations. The Court underlined that it is bound to consider judgments of the ECtHR as Ukraine ratified the ECHR, recognized the jurisdiction of the ECtHR and also because Art. 55 of the Constitution guarantees the constitutional right of every person after exhausting all domestic legal remedies to appeal for the protection of his or her rights and freedoms to the relevant international judicial institutions. Furthermore, pursuant to Art. 92 of the Constitution, the Law "On Execution of Judgments and Application of Case-Law of the European Court of Human Rights" was adopted. This law binds courts when considering cases to which the Convention is applicable and the case law of the ECHR as a source of law (Art. 17(1) $)^{305}$ and obliges courts to execute judgments against Ukraine (Art. 2).

302 Delcourt v Belgium, App. no. 2689/65 (ECtHR, 17 January 1970) para. 25; Hoffmann v Germany, App. no. 34045/96 (ECtHR, 11 October 2001) para. 65.

303 Case 3-rp/2015 (Constitutional Court, 8 April 2015) para. 2.1.

304 Ibidem, para. 2.2. See also ibidem, para. 2.3, where the Court discussed proportionality of administrative penalties and referred to the ECtHR decisions: Case Krombach v France, App. no. 29731/96 (ECtHR, 13 February 2001) para. 96 is properly cited.

305 Art. 17(1) of the Law "On Execution of Judgments and Application of Case-Law of the European Court of Human Rights" reads: "While adjudicating cases courts shall apply the Convention and the case-law of the Court as a source of law." Art. 18 provides for detailed rules on usage of the Ukrainian translations and of the original texts of the Court's decisions. English 
The other interesting thing about Ukraine is the reception of the CJEU case law through the case law of the $\mathrm{ECtHR}^{306}$ or the references to the obligation to follow the case law of the ECtHR contained in the Law of 2006 (it shows how in the view of the potential EU membership, the courts desperately needed authorization for such references). ${ }^{307}$ That was the practice of administrative courts, which started to rely on European standards i.a. on the rule of law, the principle of certainty or the principle of State liability towards individuals. In the Person $v$ Kiev City Centre for Social Assistance, the Administrative Court of the Kiev District imported the principle of legal certainty from the CJEU case law. It held that the rights of the disabled to claim social and financial assistance from the State flow from the principle of legal certainty since a State cannot justify its failure to guarantee constitutional rights by the absence of a specific national law. For authority the Court referred to the landmark decision of the CJEU in van Duyn $v$ the Home Office, ${ }^{308}$ where, as the Ukrainian Court explained, it is specified that nationals may rely on the State's obligations, even in cases when these obligations are provided in law without direct effect. ${ }^{309}$ There are probably many other CJEU judgments better suited for the reference in this case than van Duyn, but the lengths, to which the judges went to make the State responsible towards individuals is remarkable.

Last but not least, one must indicate the recent judgments of the Ukrainian courts dealing with the consequences of the occupation of Ukrainian territories. In particular, the recent case law has dealt with recognition of official documents issued on the occupied territories. They applied the so-called Namibia exception elaborated in the ICJ Advisory Opinion on Namibia. In this Opinion the ICJ observed that though the official acts of the occupant are illegal and invalid, "this invalidity cannot be extended to the acts, such as, for instance, the registration of births, deaths and marriages, the effects of which can be ignored only to

translation of the Law available at <http://sutyajnik.ru/rus/echr/etc/2006_law_ukraine.htm> (access: 25 September 2016).

306 Cf. case 1-rp/2011 (Constitutional Court, 26 January 2011) on commutation of death penalty to life imprisonment, which refers to Scopolla v Italy, App. no. 10249/03 (ECtHR, 17 September 2009) and through this decision to the judgments (cited in its para 38) of the CJEU (Joined Cases C-387/02, C-391/02, C-403/02 Berlusconi and Others, 3 May 2005) for authority that the principle of the retroactive application of the more lenient penalty formed a part of the constitutional traditions common to the EU Member States.

307 Cf. R. Petrov, P. Kalinichenko (n. 284), p. 349.

308 C-41/74 van Duyn $v$ the Home Office (CJEU, 4 December 1974).

309 Due to anonymization, the name of the applicant is not mentioned in the names of the cases. Case 4/337 (Kiev Administrative Court, 26 June 2008) cited by R. Petrov, P. Kalinichenko (n. 284). The authors emphasise that the judgment became a pattern for subsequent decisions of administrative judges (cf. cases of the Kiev Administrative Court: 5/435 (10 November 2008), 5/503 (24 November 2008); 2/416 (25 November 2008); 5/451 (1 December 2008)). See other examples ibidem, p. 349. 
the detriment of the inhabitants of the Territory."310 Ukrainian courts took into account the documents issued on the occupied Ukrainian territories to confirm deaths, births, marriages, divorces etc. emphasising that to disregard them would be contrary to human rights and the principle enshrined in the ICJ opinion. (See further in this volume Kolysnik).

\section{Conclusions}

The application of international law in the countries under our review takes place in various constitutional and legislative settings. Depending on the perceived relationship between international and domestic law, domestic courts apply international law directly (however, the scope of international law which is applied varies) or by virtue of some form of domestic incorporation as in Hungary or even in Russia or Ukraine where, despite the existence of constitutional provisions, some sort of statutory or other endorsement (like the resolutions of the plenum of supreme courts) seems to be required. We do not intend to identify the models followed in these States into monistic or dualistic since each practice exhibits straits of both. The application of international law does not depend as much on the monistic or dualistic scheme but on the broader, legal and also political context as visible by examples of Hungary, Russia or Ukraine. The judges can be more (as in Poland and the Czech Republic) or less open to considerations of international law (as in Hungary, Lithuania, Russia or Ukraine). In some countries they are more driven by parochial interests than in the others but the attitude towards international law varies also among the courts (constitutional, supreme, ordinary etc.) and individual judges in each State.

The legal settings (possibly with the exception of Ukraine) are open towards considerations based on international law but what matters in the end is practice. The latter is dependent on the particular judicial culture and the awareness on the part of the judges of peculiarities and complexity of international law. In most cases judges confine themselves to a 'simple' referring to international treaty or other international law documents. And in the majority of cases it is probably enough. Judicial interactions require good expertise in international law. That is why they are not frequent and are usually characteristic of higher courts. Yet, it must be submitted that in all examined countries the judges look to foreign or international courts' case law if confronted with new or more complex issues

310 Legal Consequences for States of the Continued Presence of South Africa in Namibia (South West Africa) notwithstanding Security Council Resolution 276 (1970), (ICJ, Advisory Opinion, 21 June 1971) para. 125. 
such as the one in Natoniewski, or the Polish Abortion and status of foetus cases or in Ukrainian cases concerning the recognition of the documents issued on the occupied territories of the country.

The judicial deference to foreign or international case law is a means of application of law, a method used by courts for various purposes. The Central and Eastern European judiciary use it similarly to other European courts. The purposes range from determining the understanding of an international law norm (interpretation), establishing the standard of protection of a right, to supporting court's own reasoning, either concurring or dissenting with the decision of the other court. Under each jurisdiction we were able to find important judgments which are worth discussion since they enrich the State practice under customary law concept (e.g. Natoniewski, Nigerian Embassy), signify developments of international law (e.g. the Czech Supreme Administrative Court case on asylum), or crystallise the perception of certain rights, institutions or effects of international law in domestic law, such as the Czech, the Hungarian, the Lithuanian or the Russian cases concerning the status of the ECtHR's decisions in respective domestic laws. We also traced exasperating symptoms of politically biased judgments using selectively international law for political purposes (e.g. Russian cases).

Finally yet importantly, it must be emphasised that language issues continue to matter. The interaction between judges depends both upon judges' linguistic skills as well as on good quality translations of their decisions into foreign languages. Judges in Central and Eastern Europe should be more focused on interaction and ensure a good quality of their decisions on important issues of international law as well as their availability to the public. In that respect, it must be positively noted that many important decisions of the constitutional courts are nowadays available at least in English.

In the light of the output of the research presented in this contribution, it is possible to conclude with regard to judicial dialogue, that it occurs more frequently in the more recent case law of the Central and Eastern European judiciary. 


\section{Bibliography}

\section{Case law}

\section{CJEU}

41/74 van Duyn v the Home Office (4 December 1974)

Joined Cases C-387/02, C-391/02, C-403/02, Berlusconi and Others (3 May 2005)

C-292/05 Irini Lechouritou et al. v Dimosio tis Omospondiakis Dimokratias tis Germanias (15 February 2007)

C-161/06 Skoma-Lux sro v Celní ředitelství Olomouc (11 December 2007)

T-85/09 Kadi v Commission (30 September 2010)

C-399/09 Marie Landtová v Česká správa socialního zabezpečení (22 June 2011)

C-154/11 Ahmed Mahamdia $v$ People's Democratic Republic of Algeria (19 July 2012)

Joined Cases C-584/10 P, C-593/10 P and C-595/10 P Commission, Council and the United Kingdom $v$ Kadi (18 July 2013)

\section{ECtHR}

Delcourt v Belgium, App. no. 2689/65 (17 January 1970)

Marckx v Belgium, App. no. 6833/74 (13 June 1979)

Soering $v$ United Kingdom, App. no. 14038/88 (7 July 1989)

Keegan v Ireland, App. no. 16969/90 (26 May 1994)

Kroon and others $v$ The Netherlands, App. no. 18535/91 (27 October 1994)

Brežnýv Slovak Republic, App. no. 23131/93 (4 March 1996)

Pezoldová v Czech Republic, App. no. 28390/95 (11 April 1996)

Nohejl v Czech Republic, App. no. 23889/93 (13 May 1996)

Jonas $v$ Czech Republic, App. no. 23063/93 (13 May 1996)

Chahal v the UK, App. no. 22414/93 (15 November 1996)

El Boujaïdi v France, App. no. 25613//94 (26 September 1997)

Krombach v France, App. no. 29731/96 (13 February 2001)

Hoffmann v Germany, App. no. 34045/96 (11 October 2001)

Görgulu v Germany, App. no. 74969/01 (26 February 2004)

Broniowski v Poland, App. no. 31443/96 (22 June 2004)

Ilaşcu v Moldova and Russia, App. no. 48787/99 (8 July 2004)

Pedersen and Badsgaard v Denmark, App. no. $49017 / 99$ (17 December 2004)

Hirst $v$ the United Kingdom (no. 2) App. no. 74025/01 (6 October 2005)

Lupsa v Romania, App. No. 10337/04 (8 June 2006)

Liu v Russian Federation, App. no. 42086/05 (6 December 2007)

Vajnai v Hungary, App. no. 33629/06 (8 July 2008)

C. G. v Bulgaria, App. no. 1365/07 (24 July 2008)

Scopolla v Italy, App. no. 10249/03 (17 September 2009)

Kononov v Latvia, App. no. 36376/04 (17 May 2010) 
Cudak v Lithuania, App. no. 15869/02 (23 March 2010)

Konstatntin Markin v Russia, App. no. 30078/06 (7 October 2010)

Paksas v Lithuania, App. no. 34932/04 (6 January 2011)

Maggio and others v Italy, App. no. 46286/09, 52851/08, 53727/08, 54486/08 and 56001/08 (31 May 2011)

Konstantin Markin v Russia, App. no. 30078/06 (22 March 2012)

Scoppola v Italy (no. 3) App. no. 126/05 (22 May 2012)

Catan and Others v Moldova and Russia, App. no. 43370/04, 8252/05, 18454/06 (19 October 2012)

Anchugov and Gladkov v Russia, App. no. 11157/04 and 15162/05 (4 July 2013)

Janowiec and Others $v$ Russia, App. no. 55508/07 and 29520/09 (21 October 2013)

Jones and Others $v$ the United Kingdom, App. no. 34356/06 and 40528/06 (14 January 2014)

OAO Neftyanaya kompaniya YUKOS v Russia, App. no. 14902/04 (24 June 2014)

OAO Neftyanaya Kompaniya YUKOS v Russia, App. no. 14902/04 (31 July 2014)

\section{ICJ}

Legal Consequences for States of the Continued Presence of South Africa in Namibia (South West Afri-

ca) notwithstanding Security Council Resolution 276 (1970), (Advisory Opinion) 1971

Gabčikovo-Nagymaros Project, (Hungary v Slovakia) (Merits) [1997] ICJ Rep 7

Jurisdictional Immunities of the State (Germany v Italy) (Merits) [2012] ICJ Rep 99

\section{Quasi-Judicial Bodies - Human Rights Committee}

Simunek, Hastings, Tuzilova and Prochazka v The Czech Republic, Communication No. 516/1992

(19 July 1995)

Josef Frank Adam v The Czech Republic, Communication No. 586/1994 (23 July 1996)

F. H. Zwaan-de Vries v The Netherlands, Communication No. 182/1984 (9 April 1987)

\section{The Czech Republic}

\section{Constitutional Court}

Pl. ÚS 19/93 (21 December 1993)

Pl. ÚS 9/94 (13 September 1994)

Pl. ÚS 33/96 (4 June 1997)

Pl. ÚS 45/97 (25 March 1998)

Pl. ÚS 19/98 (3 February 1999)

Pl. ÚS 24/98 (22 September 1999)

Pl. ÚS 9/99 (6 October 1999)

II. ÚS 120/2000 (31 May 2000)

II. ÚS 214/98 (30 January 2001)

I. ÚS 752/02 (15 April 2003)

Pl. ÚS 36/01 (25 June 2002)

Pl. ÚS 39/01 (30 October 2002)

Pl. ÚS 6/02 (27 November 2002) 
Pl. ÚS 15/02 (21 January 2003)

II. ÚS 405/02 (3 June 2003)

I. ÚS 173/04 (4 May 2004)

I. ÚS 367/03 (15 March 2005)

Pl. ÚS 11/04 (26 April 2005)

III. ÚS 252/04 (25 January 2005)

Pl. ÚS 34/04 (14 July 2005)

Pl. ÚS 43/04 (14 July 2005)

Pl. ÚS 9/05 (14 July 2005)

I. ÚS 453/03 (11 November 2005)

I. ÚS 310/05 (15 November 2006)

I. ÚS 733/05 (20 December 2006)

III. ÚS 534/06 (3 January 2007)

Pl. 4/06 (20 March 2007)

IV. ÚS 580/06 (3 April 2007)

Pl. ÚS 13/06 (6 May 2008)

Pl. ÚS 1/07 (6 May 2008)

I. ÚS 294/06 (24 June 2008)

I. ÚS 420/09 (3 June 2009)

Pl. ÚS 1/09 (28 July 2009)

III. ÚS 1012/10 (12 August 2010)

Slovak Pensions Pl. ÚS 5/12 (31 January 2012)

Pl. ÚS 28/11 (24 April 2012)

Pl. ÚS 33/11 (3 May 2012)

Pl. ÚS 17/11 (15 May 2012)

Pl. ÚS 19/12 (18 December 2012)

III. ÚS 665/11 (10 September 2013)

I. ÚS 2482/13 (26 May 2014)

Pl. ÚS 28/13 (10 July 2014)

1 Ús 860/1520 (27 October 2015)

3 ÚS 1136/13 (8 December 2015)

II. ÚS 3626/13 (18 January 2016)

\section{Supreme Court}

8 Ob 657/87 (28 June 1988)

11 Tcu 95/2003 (17 July 2003)

11 Tcu 167/2004 (16 December 2004)

21 Cdo 2215/2007 (25 June 2008)

30 Cdo 2594/2009 (24 March 2011)

23 Cdo 888/2011 (31 January 2013) 


\section{Supreme Administrative Court}

6 Ads/2003 (23 February 2005)

2 Azs 343/2004 (4 August 2005)

1 Ao $1 / 2006$ (18 July 2006)

2 As 12/2006 (29 March 2007)

9 Azs 23/2007 (14 June 2007)

1 As 39/2006 (14 June 2007)

6 As 55/2006 (11 July 2007)

1 As 13/2007 (29 August 2007)

1 Azs 40/2007 (19 September 2007)

6 Azs 215/2006 (24 October 2007)

5 Azs 28/2008 (13 March 2009)

6 Azs 40/2010-70 (29 March 2011)

3 Ads 130/2008-204 (25 August 2011)

9 Azs 107/2014-43 (29 May 2014)

\section{Hungary}

\section{Constitutional Court}

23/1993 (X. 13.) AB (13 October 1993)

53/1993 (X. 13.) AB (13 October 1993)

36/1996 (X. 13.) AB (4 September 1996)

4/1997 (I. 22.) AB (22 February 1997)

30/1998 (VI. 25.) AB (22 June 1998)

48/1998 (XI. 23.) AB (18 November 1998)

$13 / 2000$ (V. 12.) AB (12 May 2000)

$14 / 2000$ (V. 12.) AB (12 May 2000)

$5 / 2001$ (II. 28.) AB (12 March 2001)

57/2001 (XII. 5.) AB (5 December 2001)

22/2003 (IV. 28.) AB (28 April 2003)

988/E/2000 (7 October 2003)

50/2003 (XI. 5.) AB (5 November 2003)

7/2005 (III. 31.) AB (29 March 2005)

116/B/2006 (I. 9.) AB (9 January 2006)

6/2007 (II. 27.) AB (27 February 2007)

20/2007 (III. 29.) AB (29 March 2007)

21/B/2008, 154/2008 (XII. 15.) AB (15 December 2008)

$53 / 2009$ (V. 6.) AB (6 May 2009)

61/2011 (VII. 13.) AB (13 July 2011)

22/2012 (V. 11.) AB (11 May 2012)

45/2012 (XII. 29.) AB (28 December 2012)

1/2013 (I. 7.) AB (4 January 2013)

4/2013 (II. 21.) AB (21 February 2013)

$12 / 2013$ (V. 24.) AB (21 May 2013)

13/2013 (VI. 17.) AB (11 June 2013) 


\section{Lower courts}

25.P.22.432/2008/61 Fejer County Court

25.P./2008/80 Fejer County Court

\section{Lithuania}

\section{Constitutional Court}

19/94 (20 April 1995)

22/94 (24 January 1995)

8/95 (17 October 1995)

$13 / 2000-14 / 2000-20 / 2000-21 / 2000-22 / 2000-25 / 2000-31 / 2000-35 / 2000-39 / 2000-8 / 01-31 / 01$

(12 July 2001)

$41 / 2000$ (25 November 2002)

24/04 (25 May 2004)

17/02-24/02-06/03-22/04 (14 March 2006)

09/2008 (29 November 2010)

$21 / 2008$ (28 September 2011)

8/2012 (5 September 2012)

1/2013 (26 February 2013)

\section{Poland}

\section{Constitutional Court}

K 8/91 (7 January 1990)

K 26/96 (28 May 1997)

$\mathrm{P} / 8 / 0$ (4 October 2000)

SK 31/99 (24 October 2000)

K 33/02 (19 December 2002)

K 12/03 (18 February 2004)

K 18/04 (11 May 2005)

K 11/10 (19 July 2011)

\section{Supreme Court}

Judgment of 22 October 1925 (Orzecznictwo Sądów Polskich 1926-V, no. 342)

Judgment of 2 March 1926 (Orzecznictwo Sądów Polskich 1926-V, no. 418)

Judgment of 14 December 1928

Judgment of 23 October 1929

CR 1272/57 (15 May 1959)

2 CZ 70/61 (12 June 1961)

ICR 58/70 (18 May 1970)

III CZP 71/73 (5 October 1974)

III CRN 139/79 (10 October 1979)

I PRZ 8/87 (25 August 1987) 
II KRN 274/91 (17 October 1991)

I PRN 54/93 (15 June 1993)

II PK 100/05 (29 November 2005)

Natoniewski, III CSK 293/07 (13 March 2010)

IV CSK 465/09 (29 October 2010)

II CSK 456/13 (24 July 2014)

\section{Supreme Administrative Court}

OSA 2/98 (17 May 1999)

V SA 726/99 (7 December 1999)

V SA 859/99 (1 February 2000)

I SA/Łd 1707/02 (26 March 2003)

GSK 56/04 (21 April 2004)

II SA 4156/03 (16 November 2004)

II GSK 54/05 (8 February 2006)

I GSK 813/07 (22 July 2008)

I FSK 92/09 (11 March 2010)

II GSK 640/13 (24 June 2014)

\section{Lower Administrative Courts}

I SA/Bd 275/05 (Bydgoszcz Administrative Court, 20 July 2005)

I SA/Go 559/06 (Gorzow Administrative Court, 22 March 2007)

I SA/Sz 414/07 (Szczecin Administrative Court, 3 October 2007)

III SA/Lu 16/13 (Lublin Administrative Court, 30 April 2013)

IV SA/Wa 1074/14 (Warsaw Administrative Court, 7 October 2014)

IV SA/Wa 1260/14 (Warsaw Administrative Court, 23 October 2014)

\section{The Russian Federation}

\section{Constitutional Court}

B267/86 (14 October 1987)

87-O (3 July 1997)

187-O-O/2009 (15 January 2009)

8-П/2012 (27 March 2012)

27-П/2013 (6 December 2013)

6-П/2014 (19 March 2014)

21-П/2015 (14 July 2015)

12-П/2016 (19 April 2016)

\section{Supreme Court}

\section{Judgment}

987-АПГ 12-2 (7 November 2012) 


\section{Rulings of the Plenary Session of the Supreme Court}

No. 8 (31 October 1995)

No. 5 (10 October 2003) "On the Application of Universally Recognized Principles and Norms of International Law and of International Treaties of the Russian Federation by Courts of General Jurisdiction"

No. 5 (10 October 2003) "On the Application of Universally Recognized Principles and Norms of International Law and of International Treaties of the Russian Federation by Courts of General Jurisdiction" amended by the Resolution of the Plenum of the Supreme Court no. 4 (5 March 2013)

No. 23 (19 December 2003)

No. 3 (24 February 2005) "On Judicial Practice in Cases of Protection of Honour and Dignity and Business Reputation of Citizens and Legal Entities"

\section{Arbitrazh Courts}

\section{St. Petersburg Arbitrazh Court}

A56-48129/2014 [3783/2015-44531(1)] (9 February 2015)

\section{The Supreme Arbitrazh Court}

\section{Circular}

"On the Implementation of the International Treaties of the Russian Federation Referring to the Questions of Arbitration Procedure" (11 June 1999)

\section{Ukraine}

\section{Constitutional Court}

11-rp/99 (29 December 1999)

3-в/2001 (11 July 2001)

3-rp/2003 (30 January 2003)

15-rp/2004 (2 November 2004)

5 -rp/2005 (22 September 2005)

6-rp/2007 (9 July 2007)

8-rp/2010 (11 March 2010)

1-rp/2011 (26 January 2011)

16-rp/2012 (29 August 2012)

2-rp/2014 (14 March 2014)

3-rp/2015 (8 April 2015)

\section{Supreme Court}

Yuschenko v Central Election Committee of Ukraine (Supreme Court, 3 December 2004)

\section{Kiev Administrative Court}

4/337 (26 June 2008) 
$5 / 435$ (10 November 2008)

$5 / 503$ (24 November 2008)

2/416 (25 November 2008)

5/451 (1 December 2008)

\section{Courts of other jurisdictions}

\section{Canada}

\section{Supreme Court}

Provincial Judges Reference(17 September 1997) 3 S.C.R.

\section{Italy}

\section{Constitutional Court}

74/1958 (20 December 1958)

264/2012 (19 November 2012)

238/2014 (22 October 2014)

\section{Germany}

\section{Federal Constitutional Court (BVerfGE)}

Solange I 2 BvL 52/71 (29 May 1974)

Schwangerschaftsabbruch I 1 BvF 1, 2, 3, 4, 5, 6/74 (25 February 1975)

Philippinische Botschaft 2 BvM 1/76 (13 December 1977)

Böll 1 BvR 797/78 (3 June 1980)

Hitler-T-Shirt 1 BvR 680/86 (3 April 1990)

Schwangerschaftsabbruch II 2 BvF 2/90 and 4, 5/92 (28 May 1993)

rEGMR-Entscheidungen 2 BvR 1481/04 (14 October 2004)

1 BvR 204/03 (23 March 2006)

1 BvR 150/03 (1 June 2006)

2 BvR 2202/08 (18 May 2009)

\section{France}

\section{Cour de Cassation}

Islamic Republic of Iran v Société Eurodif and others, 82-12462 (14 March 1984)

\section{Slovakia}

\section{Constitutional Court}

Pl. ÚS 12/05 (4 December 2007) 


\section{United Kingdom}

\section{House of Lords}

Alcom Ltd. $v$ Republic of Colombia (12 April 1984)

Reynolds v Times News Papers Limited (28 October 1999)

$R v$ Asfaw (21 May 2008)

\section{Supreme Court}

UKSC 62 (16 October 2013)

\section{High Court of Justice}

Adimi, $R$ v Uxbridge Magistrates Court \& Anor (Queen's Bench Division, 29 July 1999)

\section{The United States of America}

\section{Supreme Court}

Marbury v Madison 5 U.S. (1 Cranch) 137 (1803) 178

Foster \& Elam v Neilson 27 U.S. (2 Pet.) 253 (1829)

Griswold v Connecticut 381 U.S. 479 (1965)

Bush v Gore 531 U.S. 98 (2000)

\section{References}

\section{Books}

Bobek M. (ed.), Central European Judges Under the European Influence the Transformative Power of the EU Revisited (Hart Publishing 2015)

Bobek M., Comparative Reasoning in European Supreme Courts (Oxford University Press 2013)

Buromenskyy M., International Law: Manual for students [in Ukrainian] (Kharkiv 2005)

Crawford J., Brownlie's Principles of Public International Law ( $8^{\text {th }}$ ed., Oxford University Press 2012)

Dezső M. et al., Constitutional Law in Hungary (Kluwer Law International 2010)

Dupré C., Importing the Law in Post-Communist Transitions: The Hungarian Constitutional Court and the Right to Human Dignity (Oxford: Hart 2003)

Halliday S., Autonomy and Pregnancy, A Comparative Analysis of Compelled Obstetric Intervention (Routledge 2016)

Mälksoo L., Russian Approaches to International Law (Oxford University Press 2015)

Mälksoo L., Theory of International Law in Contemporary Russia (Oxford University Press 2015)

Martinico G., Pollicino O., The Interaction between Europe's Legal Systems Judicial Dialogue and the Creation of Supranational Laws (Edward Elgar 2012)

Torres-Pérez A., Conflicts of Rights in the European Union: A Theory of Transnational Adjudication (Oxford University Press 2009)

Van Elsuwege P., Petrov R., Legislative Approximation and Application of EU law in the Eastern Neighbourhood of the European Union, Toward a Common Regulatory Space (Routledge 2014) 
Wójtowicz K., Constitutional Courts and European Union Law (Faculty of Law, Administration and Economics University of Wroclaw, e-Monographies 2014), <http://www.bibliotekacyfrowa. pl/Content/63576/Constitutional_courts.pdf> (access: 25 August 2016)

Wyrozumska A., Umowy międzynarodowe. Teoria i praktyka [International Treaties. Theory and Practice] (Wydawnictwo Prawo i Praktyka Gospodarcza 2006)

\section{Books Sections}

Abashidze A., 'The Relationship Between International Law and Municipal Law: Significance of Monism and Dualism Concepts', [in:] Basic Concepts of Public International Law, Monism \& Dualism (Faculty of Law of Belgrade University May 2013)

Bělohlávek A.J., 'The Czech Republic', [in:] Shelton D.L. (ed.), International Law and Domestic Legal Systems: Incorporation, Transformation, and Persuasion (Oxford University Press 2011) 195

Bóka J., 'Use of the Comparative Method by the Hungarian Constitutional Court - Conceptual and Methodological Framework for an Ongoing Research Project', [in:] Badó A., Detlev W.B., Bóka J., Mezei P. (eds), Internationale Konferenz zum zehnjährigen Bestehen des Instituts für Rechtsvergleichung der Universität Szeged (Acta Iuridica Universitatis Potsdamiensis, Universitätsverlag Potsdam 2014) 93-107

Butler W.E., 'Russian Federation', [in:] Sloss D. (ed.), The Role of Domestic Courts in Treaty Enforcement, A Comparative Study (Cambridge University Press 2014) 410

Chronowski N., Drinóczi T., Ernszt I., 'Hungary', [in:] Shelton D.L. (ed.), International Law and Domestic Legal Systems: Incorporation, Transformation, and Persuasion (Oxford University Press 2011)

Garlicki L., Masternak-Kubiak M., Wójtowicz K., 'Poland', [in:] D. Sloss (ed.), The Role of Domestic Courts in Treaty Enforcement, A Comparative Study (Cambridge University Press 2013) 370

Hoffman T., 'Trying Communism through International Criminal Law? The Experiences of the Hungarian Historical Justice Trials, [in:] Heller K.J., Simpson G. (eds), The Hidden Histories of War Crimes Trials (Oxford University Press 2013) 229

Kowalik-Bańczyk K., 'Report on Poland', [in:] Martinico G., Pollicino O. (eds), The National Judicial Treatment of the ECHR and EU Laws, A Comparative Constitutional Perspective (Groningen: Europa Law Publishing 2010) 329

Kwiecień R., Miejsce umów międzynarodowych w porządku prawnym państwa polskiego [Place of International Treaties in the Legal Order of the Polish State] (Warszawa 2000)

Mälksoo L., 'Russia and European Human-Rights Law: Progress, Tensions and Perspectives', [in:] Mälksoo L. (ed.), Russia and European Human Rights Law: The Rise of the Civilizational Argument (Brill Nijhoff 2014) 5

Sonnevend P., 'Report on Hungary', [in:] Martinico G., Pollicino O. (eds), The National Judicial Treatment of the ECHR and EU Laws, A Comparative Constitutional Perspective (Groningen: Europa Law Publishing 2010) 258

Tikhomirov Y., 'Russia, [in:] Shelton D.L. (ed.), International Law and Domestic Legal Systems: Incorporation, Transformation, and Persuasion (Oxford University Press 2011) 517

Uitz R., 'The illusion of the constitution in Europe: The Hungarian Constitutional Court after the Fifth Amendment of the Fundamental Law', [in:] Bell J., Paris M.-L. (eds), Right-Based Constitutional Review: Constitutional Courts in a Changing Landscape (Edward Elgar Publishing 2016) 374 
Vasilev A.M., 'On the Systems of Soviet and International Law' (1985) 1 Sovietskoje gosudarstwo i prawo 69, von Bogdandy A., Sonnevend P. (eds), Constitutional Crisis in the European Constitutional Area, Theory, law and Politics in Hungary and Romania (Hart Publishing 2015) 5

Wyrozumska A., 'Poland', [in:] Shelton D.L. (ed.), International Law and Domestic Legal Systems: Incorporation, Transformation, and Persuasion (Oxford University Press 2011) 468

\section{Articles}

Anagnostaras G., 'Activation of the Ultra Vires Review: The Slovak Pensions Judgment of the Czech Constitutional Court' (2013) 14 German Law Journal 959

Babai N., Timoshenko V.S., 'General Principles and Norm of International Law in the Russian Legal System' (2007) 1 Russian Law: Theory and Practice 77

Belianskaia O.V., Pugina O.A., 'Implementation of International Legal Norms in Russian Legislation' (2006) 1 Russian Law: Theory and Practice 82

Blutman L., Chronowski N., 'Hungarian Constitutional Court: Keeping Aloof from European Union' (2011) 5 Vienna Journal on International Constitutional Law 329

Burkov A.L., 'Implementation of the Convention for the Protection of Human Rights and Fundamental Freedoms in Russian Courts' (2006) 1 Russian Law: Theory and Practice 68

Burkov A., 'Motivation for Direct Application of the Convention for the Protection of Human Rights and Fundamental Freedoms in Russian Courts' (2012) 12 Baltic Yearbook of International Law 229

Choudry S., 'Globalization in Search of Justification: Toward a Theory of Comparative Constitutional Interpretation' (1999) 74 Indiana Law Journal 819

Chronowski N., Csatlós E., 'Judicial Dialogue or National Monologue? The International Law and Hungarian Courts' (2013) 1 ELTE Law Journal 7

Csatlós E., 'The Application of International Law as an Instrument of Interpretation in Hungary - The Practice of the Constitutional Court and Ordinary Courts in a Comparative Approach', $<$ https://publishup.uni-potsdam.de/opus4.../S127-142_aiup01.pdf> (access: 25 September 2016)

Ishchenko O.A., Ishchenko E.G., 'Implementation of International Law in Russian Legislation' (2008) 2 Russian Law: Theory and Practice 196

Komárek J., 'Czech Constitutional Court Playing with Matches: The Czech Constitutional Court Declares a Judgment of the Court of Justice of the EU Ultra Vires' (2012) 8 European Constitutional Law Review 323

Kovics K., 'Cooperative Decision-making: The Relation between Hungary and Strasbourg' (2011) 5(2) Vienna Journal on International Constitutional Law 188-199

Krisch N., 'The Open Architecture of European Human Rights' (2008) 71 Modern Law Review 183 Mälksoo L., 'Casenote on Markin v Russia' (2012) 106 American Journal of International Law 836

Mälksoo L., 'International Law in Russian Textbooks: What's in the Doctrinal Pluralism?' (2009) 1 Goettingen Journal of International Law 279

Marochkin S.Yu., 'Contemporary Approaches of the Russian Doctrine to International Law: Identical to Western Ones?' (2012) 12 Baltic Yearbook of International Law 29

Marochkin S.Yu., 'International Law in the Courts of the Russian Federation: Practice of Application' (2007) 6 Chinese Journal of International Law 239 
Marochkin S.Yu., Popov V.A., 'International Humanitarian and Human Rights Law in Russian Courts' (2011) 2 International Humanitarian Legal Studies 216

McCrudden Ch., 'Human Dignity and Judicial Interpretation of Human Rights' (2008) 19 European Journal of International Law 655

McCrudden Ch., 'A Common Law of Human Rights?: Transnational Judicial Conversations on Constitutional Rights' (2000) 20 Oxford Journal of Legal Studies 499

Mikeš P., 'Czech Courts and International Law' (2011) 2 Czech Yearbook of International Law 289

Molek P., 'The Court that Roared: The Czech Constitutional Court Declaring War of Independence against the ECJ' (2012) 6 European Law Reporter 162

Petrov R., Kalinichenko P., 'The Europeanization of Third Country Judiciaries through the Application of the EU Acquis: The Cases of Russia and Ukraine' (2011) 60 International and Comparative Law Quarterly 325

Prescott N., 'Orange Revolution in Red, White and Blue: US Impact on the 2004 Ukrainian Election' (2006) 16 Duke Journal of Comparative \& International Law 219

Rozmaryn S., 'Skuteczność umów międzynarodowych PRL w stosunkach wewnętrznych' [Effectiveness of International Treaties in Poland’s Internal Relations] (1962) 12 Państwo i Prawo 954

Slaughter A.M., 'A Global Community of Courts' (2003) 44 Harvard International Law Review 191

Slaughter A.M., 'A Typology of Transjudicial Communication' (1994) 29 University of Richmond Law Review 99

Tkatova R., 'Russian spirit, Soviet Heritage and Western Temptation: "UN-Peaceful Coexistence”, [in:] Russia's International Doctrine and Practice' (2012) 12 Baltic Yearbook of International Law 1

Vaypan G., 'Acquiescence Affirmed, Its Limits Left Undefined: The Marking Judgment and the Pragmatism of the Russian Constitutional Court vis-à-vis the European Court of Human Rights' (2014) II Russian Law Journal 130

Vorontsova I.V., 'Problems of International Law Interpretation (on the example of the Convention on the Protection of Human Rights and Fundamental Freedoms) in the light of the ECtHR judgment in the case of K. Markin' (2015) 1 Russian Law: Theory and Practice 100

Wilkinson D., 'Interpreting Ukrainian legislation in light of international law and jurisprudence' НАУКОВІ ЗАПИСКИ, Том 22, Частина IІ, УДК 341.231.14, 223, <http://lawinfo.ru/catalog/ contents-2015/russian-law/1/8664> (access: 25 September 2016)

Zbíral R., 'A Legal Revolution or Negligible Episode? Court of Justice Decision Proclaimed Ultra Vires' (2012) 49 Common Market Law Review 1457

\section{Other}

Dyevre A., 'Domestic Judicial Non-Compliance in the European Union: A Political Economic Approach' (2013) 2 LSE Law, Society and Economy Working Papers 1

Martinico G., 'A Matter of Coherence in the Multilevel Legal System: Are the "Lions" Still "Under the Throne"?' Jean Monnet Working Paper 16/08, New York University, New York

Murphy C.C., 'Human Rights Law and the Challenges of Explicit Judicial Dialogue' Jean Monnet Working Paper 10/12 